Andrews University

Digital Commons @ Andrews University

2016

\title{
Capacity Building for International Development Practitioners Through an Off-Campus Graduate Education Program
}

\author{
Ralph Charles Wood \\ Andrews University, rwood@andreews.edu
}

Follow this and additional works at: https://digitalcommons.andrews.edu/dissertations

Part of the Other International and Area Studies Commons

\section{Recommended Citation}

Wood, Ralph Charles, "Capacity Building for International Development Practitioners Through an OffCampus Graduate Education Program" (2016). Dissertations. 1594.

https://digitalcommons.andrews.edu/dissertations/1594

https://dx.doi.org/10.32597/dissertations/1594

This Dissertation is brought to you for free and open access by the Graduate Research at Digital Commons @ Andrews University. It has been accepted for inclusion in Dissertations by an authorized administrator of Digital Commons@ Andrews University. For more information, please contact repository@andrews.edu. 
Andrews University

School of Education

\title{
CAPACITY BUILDING FOR INTERNATIONAL DEVELOPMENT PRACTITIONERS THROUGH AN OFF-CAMPUS GRADUATE EDUCATIONAL PROGRAM
}

\author{
A Dissertation \\ Presented in Partial Fulfillment \\ Of the Requirements for the Degree \\ Doctor of Philosophy
}

by

Ralph Charles Wood, Jr

May 2016 
(C) Copyright by Ralph Charles Wood, Jr 2016

All Rights Reserved 


\title{
CAPACITY BUILDING FOR INTERNATIONAL DEVELOPMENT PRACTITIONERS THROUGH AN OFF-CAMPUS GRADUATE EDUCATIONAL PROGRAM
}

\author{
A dissertation \\ presented in partial fulfillment \\ of the requirements for the degree \\ Doctor of Philosophy \\ (Doctor of Education)
}

\section{by}

Ralph Charles Wood, Jr.

\section{APPROVAL BY THE COMMITTEE:}

Chair: Larry D. Burton

Member: Øystein S. LaBianca

Member: Clive W. Holland

External Member: Alayne Thorpe

Member: Clive W. Holland
Dean, School of Education:

Robson Marinho 
In memory of my parents

Ralph C. (1920-2012) \& Mildred A. (1922-2012) Wood and my maternal grandmother Emma (Sidwell) Goode (1900-1999) 


\begin{abstract}
CAPACITY BUILDING FOR INTERNATIONAL DEVELOPMENT PRACTITIONERS THROUGH AN OFF-CAMPUS GRADUATE EDUCATIONAL PROGRAM
\end{abstract}

by

Ralph Charles Wood, Jr.

Chair: Larry D. Burton 


\section{ABSTRACT OF GRADUATE STUDENT RESEARCH}

Dissertation

Andrews University

School of Education

\section{Title: CAPACITY BUILDING FOR INTERNATIONAL DEVELOPMENT PRACTITIONERS THROUGH AN OFF-CAMPUS GRADUATE EDUCATIONAL PROGRAM}

Name of researcher: Ralph Charles Wood, Jr.

Name and degree of faculty chair: Larry Burton, $\mathrm{PhD}$

Date completed: May 2016

\section{Problem}

Andrews University offers a graduate off-campus program in international development, the Master of International Development Administration (MIDA). The stimulus for this study came from the fact that there had never been an extensive investigation of the capacity building impact on the graduates of the off-campus Master of International Development Administration of Andrews University. Coupled with this, there was a very limited body of research on the importance and effect of education in international development when it comes to building the capacity of the practitioners of international development. This study determined the alumni's perceptions of experiencing individual capacity building and transference of learning to the organizations that employ them. Just as important it also proposed an original grounded 
theory about capacity building and tested the capacity building theoretical framework of this study.

\section{Method}

The research design used in this investigation is an explanatory ex-post-facto quantitative methodology design. There are also elements of qualitative data within the research process. There were six dependent variables: experienced individual capacity building, project cycle management, course delivery, andragogy, transformational learning, and transference of learning. There were two independent variables: gender and age.

A survey questionnaire was developed to collect data on each variable from a random sample of the alumni $(n=70)$ who took their course work in English was surveyed. Two-way multivariate analysis of variance, one-way analysis of variance, frequency analysis, and path analysis were used to determine similarities, differences, and inter-correlations among the variables.

\section{Results}

Alumni's overall perception of the MIDA program was excellent, "It enabled me to achieve my goals" (Maurice). Over $92 \%$ of the graduates thought they had experienced individual capacity building while in the program. The use of project cycle management as the basis around which to build the international development curriculum was highly valued by the alumni. Alumni indicated that the courses were delivered by professors that were knowledgeable and were open in their communication with the students. From the alumni's perspective the principles and concepts of andragogy and 
transformative learning were upheld. A little over $86 \%$ of the respondents perceived they had transferred learning to their organization, while $13 \%$ had not. In contrast with the World Bank's (Chin, 2008) experience which revealed that the transference of individual capacity building learning to the organizations was successful only about half the time. Because of the graduate program in capacity building in international development the alumni perceived that they were transferring their learning to their employing organizations and enabled them to advance the organizations own mission and goals. An unexpected result of the MIDA program was that over half of the alumni who worked for faith-based NGO's when they entered the program are now employed by a different type of organization.

Path analysis confirmed the veracity of the tested components of the study's theoretical framework. Almost 70 percent of the variable "experiencing individual capacity building" was directly attributed to 4 variables: "project cycle management," "andragogy," "course delivery," and "transformative learning." Results also showed that 77 percent of "transference of learning" was directly accredited to "experiencing individual capacity building," and indirectly influenced by the other 4 variables, and about $23 \%$ was due to unexplained or unknown factors.

\section{Conclusions}

Results from this study showed that a strong correlation of the alumni's perception experiencing capacity building as an individual and the transference of their learning to their employing organizations due to the graduate educational program in international development to which they were exposed. 


\section{TABLE OF CONTENTS}

LIST OF FIGURES …....................................................................... xiii

LIST OF TABLES .............................................................................

LIST OF ABBREVIATIONS ..................................................................

Chapter

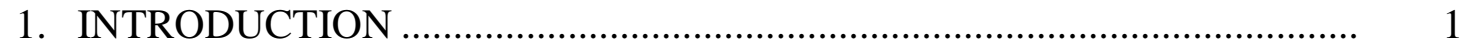

Program Background ............................................................. 1

Master of International Development Administration Program ...... 1

Capacity Building ........................................................................ 3

Statement of Problem..................................................................... 4

Purpose of This Study ............................................................... 5

Research Questions and Related Hypotheses ................................ 6

Significance of the Study ............................................................ 8

Research Method ........................................................................... 9

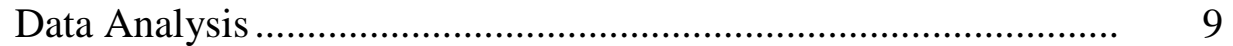

Delimitation ......................................................................... 10

Personal Involvement in International Development ................... 11

Personal Philosophy on Development ........................................ 13

Adventist Development and Relief Agency ..................................... 13

ADRA and Andrews University ................................................... 14

The Master of International Development Program ...................... 15

Project Cycle Management .................................................. 17

Defining Capacity Building ................................................... 21

Use of the Term Capacity Building .............................................. 22

Andragogy and the Adult Learner ............................................ 23

The Mystery of Transformative Learning.................................... 25

Outline of the Remainder of the Proposal...................................... 28

2. LITERATURE REVIEW ............................................................... 30

International Development Overview .......................................... $\quad 30$

Defining International Development ....................................... 31

Development Organizations....................................................... 32

International Development Terminology..................................... 34 
Education and Capacity Building ………………………….............. 35

Capacity Building Opportunities in International Development ..... 36

On-the-Job Training Experiences …………………………........ 36

Internship Experience ........................................................... 36

In-service Workshops or Seminars …………………….......... $\quad 39$

Education ...................................................................... 40

Cross Border Education .......................................................... 40

Effects of Capacity Building.......................................................... 42

Effectiveness of Capacity Building ............................................... 44

The Use of Alumni Surveys in Academia .......................................... 48

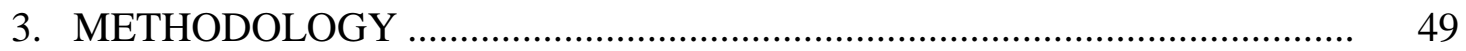

The Research Design and Subjects Defined ...................................... 49

Study Population ………………......................................... 49

Study Variables and Null Hypotheses ............................................. 50

Null Hypotheses...................................................................... 52

Instrumentation ..................................................................... 53

Procedures........................................................................ 54

Data Collection ...................................................................... 54

Data Cleaning......................................................................... 56

Data Analysis ........................................................................... 57

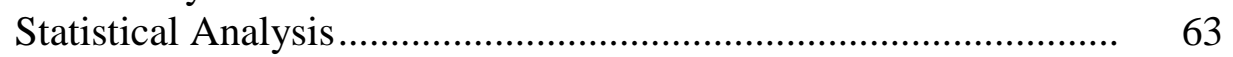

Hypothesis Testing........................................................................ 64

Protection of Human Subjects .................................................... 64

Delimitations of Research............................................................. 65

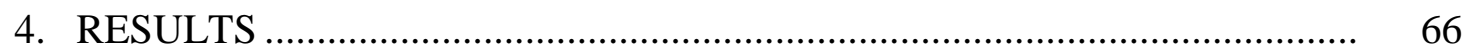

Demographic Analysis..................................................................... 67

Responses to the Research Questions .................................................. 73

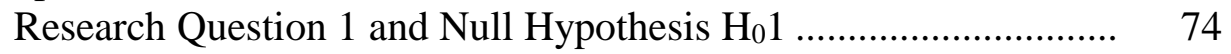

Research Question 2 ................................................................ $\quad 77$

Research Question 3 .............................................................. 78

Research Question 4 ........................................................... 82

Research Question 5 ........................................................ 83

Research Question 6 ................................................................. 85

Research Question 7 ................................................................. 87

Research Question 8 and Null Hypothesis $\mathrm{H}_{0} 2$............................ 88

Research Question 9 .............................................................. 93

Strengths of the Program ......................................................... 94

Areas of Improvement in the Program........................................ 96

Present and Future Needs of the International

Development Community ................................................. 99 
Research Question 10

Concepts/Principles that Need to be Included in the

Curriculum

\section{EVALUATION FINDINGS, THEORY DEVELOPMENT,} DISCUSSION, AND RECOMMENDATIONS

Background

Purpose of the Study ............................................................. 108

Related Literature................................................................... 109

Learning Theories: Andragogy and Transformative Learning ....... 109

International Development....................................................... 111

Education and International Development................................. 111

The Use of Alumni Surveys.................................................... 113

Theoretical Framework for Study ............................................ 113

Methodology ......................................................................... 114

Major Findings of the Evaluation Study ....................................... 115

Demographics ................................................................... 115

Inferential Analysis .............................................................. 117

Frequency Analysis ............................................................ 118

Path Analysis ....................................................................... 120

Open-Ended Question Analysis ................................................ 121

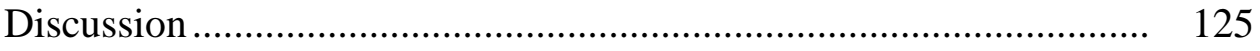

Type of Organization .............................................................. 125

Alumni's Perceptions of Experiencing Individual Capacity

Building.................................................................... 127

Alumni’s Perceptions of Course Delivery ................................... 127

Alumni’s Perceptions of Project Cycle Management.................... 131

Alumni's Perceptions of Andragogy ........................................... 132

Alumni's Perceptions of Transformative Learning Theory............. 132

Alumni's Perceptions of Transference of Learning........................ 133

Inter-Correlations of the Dependent Variables ............................. 136

Potential Lessons for Other AU Off-Campus Programs.................... 137

Recommendations for Practice ......................................................... 139

Theory Development ................................................................ 140

Life-span Development............................................................. 140

Capacity Building ......................................................................... 141

Capacity Building Theoretical Framework................................... 142

If-Then Logic Statement ........................................................... 145

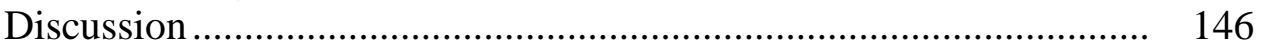

Recommendations for Research ................................................ 147

Limitations of the Study............................................................... 149

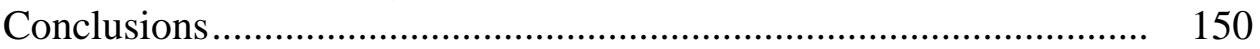




\section{APPENDICES}

A. CAPACITY BUILDING AND ITS VARIABLES …............................ 153

B. SURVEYS AND LETTERS …........................................................ 156

C. IRB AND NIH DOCUMENTS .................................................... 182

D. LETTER OF PERMISSION TO USE JARVIS ILLUSTRATION .......... 185

E. $\quad$ LISTS OF MIDA ALUMNI DEGREES ............................................ 187

F. UNEDITED MIDA ALUMNI RESPONSES TO OPEN-END

QUESTIONS ....................................................................... 190

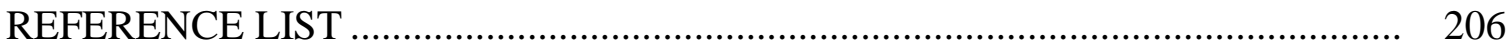

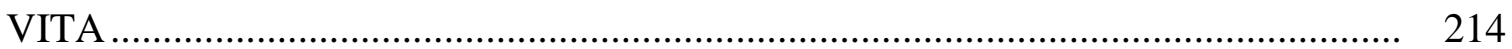




\section{LIST OF FIGURES}

1. Proposed MIDA Capacity Building Path Analysis Model ............................... 9

2. Project Cycle Management and Their Relationship to MIDA Core Courses ....... 18

3. The Transformation of the Person Through Learning ...................................... 26

4. Capacity Building Opportunities .............................................................. 37

5. Capacity Building Ripple Effect .............................................................. 43

6. Path Analyses of the Study Variables ......................................................... 90

7. Theoretical Framework for Capacity Building in International Development...... 143 


\section{LIST OF TABLES}

1. Drivers of Program Success ...................................................................... 47

2. Variable Types, Variable Names, and Operational Definitions ....................... 51

3. Research Questions, Hypotheses, Variables, and Statistics............................ 58

4. Types of Organizations the Alumni are Employed by: Beginning of

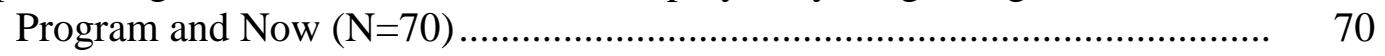

5. Types of Organizations the Alumni are Employed by: Beginning of

Program and Now According to Gender $(\mathrm{N}=70)$..................................... 71

6. Present Responsibilities Compared With Before the MIDA Program by

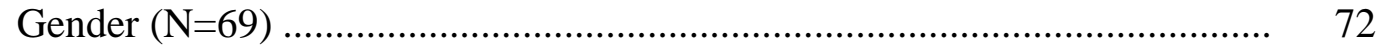

7. Results of Simultaneous Multiple Regression to Predict of Alumni Impact on

Transference of Learning (Y) From PCM, TrLn, Andr, CoD1, CaBd.......... 75

8. Analysis of Simple Main Effects for Gender............................................... 76

9. Analysis of Simple Main Effects for Present Age ….................................. 76

10. Individual Capacity Building and the MIDA Alumni ...................................... 77

11. MIDA Course Delivery and the MIDA Alumni ............................................ 79

12. Project Cycle Management (PCM) and the MIDA Alumni ............................. 82

13. The Use of Andragogy Theory and the MIDA Alumni................................... 84

14. The Use of Transformative Learning and the MIDA Alumni ............................ 86

15. MIDA Alumni Transference of Learning to Their Employing Agency .............. 87

16. Summary of the Causal Effects of the Capacity Building Model....................... 91

17. Summary of the Correlations of the Exogenous Variables of the Capacity

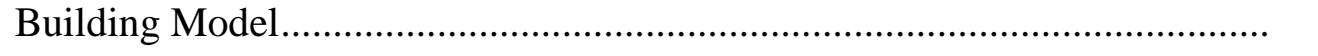




\section{LIST OF ABBREVIATIONS}

ADRA Adventist Development and Relief Agency

AIDS Acquired Immunodeficiency Syndrome

ANOVA Analysis of Variance

AU Andrews University

BRAC Bangladesh Rural Advancement Committee

CRS Catholic Relief Services

DANIDA Danish International Development Agency

EuroAID European Aid Cooperation Office

FAO Food and Agriculture Organization

HIV Human Immunodeficiency Virus

HRD Human Resource Development

IBM International Business Machines

IRB Institutional Review Board

JICA Japan International Cooperation Agency 
LDC Less Developed Countries

MANOVA Multivariate Analysis of Variance

MIDA Master of International Development Administration

MOU Memorandum of Understanding

NFI Normal Fit Index

NGO Non-governmental Organization

NGOs Non-governmental Organizations

NIH National Institute of Health

NORAD Norwegian Development Agency

IDP International Development Program

PCM Project Cycle Management

OECD Office for Economic Cooperation and Development

OJT On-the-job Training

SDA Seventh-day Adventist

SAWS Seventh-day Adventist World Service

SIDA Swedish International Development Agency

SPSS Statistical package for the Social Sciences 


$\begin{array}{ll}\text { UN } & \text { United Nations } \\ \text { UNDP } & \text { United Nations Development Program } \\ \text { UNEP } & \text { United Nations Economic Development } \\ \text { UNESCO } & \text { United Nations Education, Science and Cultural Organization } \\ \text { US } & \text { United States } \\ \text { USAID } & \text { United States Agency for International Development } \\ & \end{array}$


Xviii 


\section{CHAPTER 1}

\section{INTRODUCTION}

\section{Program Background}

Andrews University is an institution of higher learning of the Seventh-day Adventist (SDA) Church located in Berrien Springs, Michigan. It offers undergraduate and graduate degrees up through the doctoral level. Its mission statement makes it clear that it is a "distinctive Seventh-day Adventist Christian institution" that "transforms its students" (Andrews University, 2013 p. 6) through education. Andrews' students are encouraged to "seek knowledge" and "affirm their faith" (p. 6) that upon graduation they leave the institution as alumni who are equipped "to change" (p. 6) the world.

\section{Master of International Development Administration Program}

One of the academic programs that Andrews University offers is a graduate offcampus program in international development, the Master of International Development Administration (MIDA). This international development program was originally created for the employees of the Adventist Development and Relief Agency (ADRA), a humanitarian non-governmental organization (NGO) within the Adventist Church. The intention of this program was to provide a graduate educational curriculum "to build capacity in leadership" (Andrews University, 2013, p. 123) throughout the ADRA organization. The MIDA program has evolved so that it now "provide(s) a venue for 
leadership training of professionals" for personnel of other NGOs, government, public, and private organizations "whose work responsibilities and life situations do not permit full-time study at a university campus" (Andrews University, 2012, p. 125). In 2013 there were 449 students enrolled in the MIDA program, making it Andrews University's largest off-campus academic program.

Previous to the MIDA program ADRA had attempted to build capacity of their personnel by intermittent in-house short-term workshops and seminars. For the most part these in-service efforts or endeavors had no organizing theme that lent itself to real international development capacity building within the organization.

Many of the individuals who work within the international development arena come from a wide variety of professional backgrounds and experiences. They include professionals such as educators, ministers, accountants, health professionals, and agronomists. The one reoccurring aspect that these individuals lacked was a comprehensive understanding of international development, even though they were actively involved in it. The main goal of this off-campus Master of International Development Administration of Andrews University was to help fill this void of understanding.

Most of the potential students for the MIDA program are at a mid-career stage within their life-span in terms of their professional development and maturity. Therefore, pedagogically attributes of andragogy and transformative learning theory were taken into account when the capacity building MIDA curriculum was being developed.

The core courses for the MIDA curriculum in capacity building are organized around the model of project cycle management (PCM). PCM was developed by the 
European Aid Cooperation Office (EuroAID) to serve as a guideline and standard for project development, management, and evaluation for the international development community, it practitioners, and organizations (European Commission, 2004).

\section{Capacity Building}

Capacity building has been a concept that has been difficult to come to terms with. There seems to be no leading theorist(s) to formulate what capacity building is and its practicable applications and implementation, especially in the arena of international development.

For many capacity building is a process to strengthen an organization so that it can fulfill its mission (Connolly \& Lukas, 2002; DeVita \& Flemming, 2001; United Nations Development Programme, 2007). But organizations do not build themselves. They are the results of human endeavor. Capacity building, a way to people-centered development, emerged in the 1980s from the human resource development concept for institutional development. From the latter part of the 1990s to the present the international development community looks upon capacity building as the means to do and further development (Lusthaus, Adrien, \& Perstinger, 1999).

For capacity building to be successful an individual, who is employed by an organization, needs to increase their own international development capacity building potential through the transference of their learning so that the mission and work of that organizations can be successful. By this means the organization can strengthen its own sustainable capacity building to be able to serve, and increase capacity building development of society down to the grassroots level of the family, and the individual 
(Chin, 2008; Crocker \& Schwenke, 2005; de Crombrugghe, 2010; Horton, 1998).

It has been challenging to quantify the academic effectiveness of capacity building. Individuals who have been in educational capacity building programs think their learning has improved, but the World Bank has found that overall improvement at the organizational level was effective about half the time. A person's personal improvement in capacity building is not a useful gauge to predict heightened performance at the organizational level (Chin, 2008).

\section{Statement of Problem}

A majority of the individuals who work for ADRA, other NGOs, and humanitarian organizations, in either relief and/or development, have come from a wide variety of professions and professional experiences. Examples include, among others, pastors, agriculturalists, medical and public health professionals, educators, and accountants. What most of these professionals lacked was a cohesive understanding of international development work, the requisite management skills to be more effective in reaching out to clients in the developing countries, and the skills to meet the expectations of the agencies funding these organizations.

ADRA leadership attempted to build capacity in their personnel in the past by having in-house short-term, workshops or seminars. These workshops or seminars usually ranged from three-day to two-week events on an irregular basis as the need arose over a wide range of subjects. But there was no real comprehensive overarching theme to the collective aggregate of this kind of capacity building. ADRA leadership recognized that the agency needed an academically driven human resource development program 
with the goal of capacity building for their existing staff at all organizational levels.

With the implementation of this off-campus graduate degree program in international development Andrews University was trying to meet this capacity building void for ADRA. Since Andrews University and ADRA have invested time, energy, money, and human resources into this endeavor it is important to understand the impact of the program upon the students, and the organizations they serve. The bottom line question is: Did the unique contributions of each component of this graduate program in capacity building create successful learning because of the unique contributions of each component?

\section{Purpose of This Study}

The purpose of this dissertation is to investigate perceptions of the quality of the off-campus Master of International Development Administration program of Andrews University, its capacity building effect(s) upon its alumni, and the alumni's perception of transference of learning to the organizations that employ them. The first objective of the study is to ascertain if alumni believe they have developed capacity to function more effectively and efficiently because of their participation in the MIDA program. The second objective is to evaluate from the alumni's perspectives the academic strengths and challenges of the MIDA curriculum as it pertains to capacity building in the arena of international development. The third objective is to parse out what lessons can be learned from this off-campus program and how Andrews University can apply these lessons to other off-campus graduate programs. 


\section{Research Questions and Related Hypotheses}

Research questions drive the whole research agenda, process and purpose. It is the central role of the researcher(s) to ask specific questions so that the study is well defined, keeps the research process in focus, and hopefully prevents the study from becoming unwieldy, and unmanageable both in time and resources. The questions themselves arise from identifying problems from the literature on the subject being studied, practice, or experiences of the researcher(s) (Tashakkori \& Teddlie, 2010).

Research Question 1: Do differences exist by gender and present age in MIDA alumni perceptions of project cycle management, transformative learning, andragogy, course delivery, experiencing individual capacity building, and transference of learning?

Null Hypothesis $H_{0}$ 1:There are no statistically significant differences by gender and present age in MIDA alumni perceptions of project cycle management, transformative learning, andragogy, course delivery, experiencing individual capacity building, and transference of learning?

Research Hypothesis 1: There are statistically significant differences by gender and present age in MIDA alumni perceptions of project cycle management, transformative learning, andragogy, course delivery, experiencing individual capacity building, and transference of learning?

Research Question 2: What are MIDA alumni perceptions of experiencing individual capacity building while in the program?

Research Question 3: What are MIDA alumni perceptions of the effectiveness of the teaching, learning, and course delivery processes used for this program?

Research Question 4: What are MIDA alumni perceptions of using project cycle 
management to organize the program curriculum?

Research Question 5: What are MIDA alumni perceptions of the use of andragogy in the program?

Research Question 6: What are MIDA alumni perceptions of the inclusion of transformative learning theory in the program?

Research Question 7: What are MIDA alumni perceptions of their contribution to the overall mission and work of their employing agency?

Research Question 8: Are project cycle management, transformative learning, andragogy, course delivery, significant predictors of transference of learning mediated by experiencing individual capacity building to their organization?

Null Hypothesis $\mathrm{H}_{0} 2$ : Project cycle management, transformative learning, andragogy, course delivery, are not significant predictors of transference of learning mediated by experiencing individual capacity building to their organization.

Research Hypothesis 1: Project cycle management, transformative learning, andragogy, course delivery, are significant predictors of transference of learning mediated by experiencing individual capacity building to their organization

Research Question 9: What are the MIDA alumni thoughts and opinions of the off-campus Andrews University Master in International Development Administration in terms of strength(s), areas for improvement, and opportunities for meeting current and future international development needs?

Research Question 10: What are the MIDA alumni thoughts and opinions of the off-campus Andrews University Master in International Development Administration of important courses or concepts that need to be included in the curriculum, or important 
concepts or principles that they learned from the program?

\section{Significance of the Study}

This study is significant for five reasons. First, this study will evaluate the efficacy of an academic international development program designed around the phases of project cycle management. Each phase serves as an anchor point for individual capacity building. Findings from this research question have potential implications for international development programs worldwide.

Second, this study will investigate the practical application of andragogy and transformational learning theory. Determining what aspects of andragogy and transformational learning theory have the greatest impact on capacity building learning outcomes will help validate or realign the theoretical framework for this study. This will enable the study's findings to provide program developers and instructors data-based evidence for future program, course, lesson, and project development.

Third, the study will provide data on the possible transference of learning through experiencing individual capacity building to strengthen the mission and work of the organizations employing the alumni. If this study is able to show consistent transference to the workplace it will be a major contribution to the literature. A previous evaluation of capacity development training supported by the World Bank (Chin, 2008) showed high levels of personal capacity building development followed by low levels of impact on the organization.

Fourth, this study proposes a capacity building causality relationship path analysis model that demonstrates the path of how transference of learning occurs because of 
project cycle management, transformative learning, andragogy, experience individual capacity building, and course delivery curriculum of the MIDA program (see Figure 1) (de Crombrugghe, 2010).

Finally, the lessons learned from the evaluation of this off-campus program will provide important information for how Andrews University administrators and faculty can apply these lessons to other off-campus graduate programs.

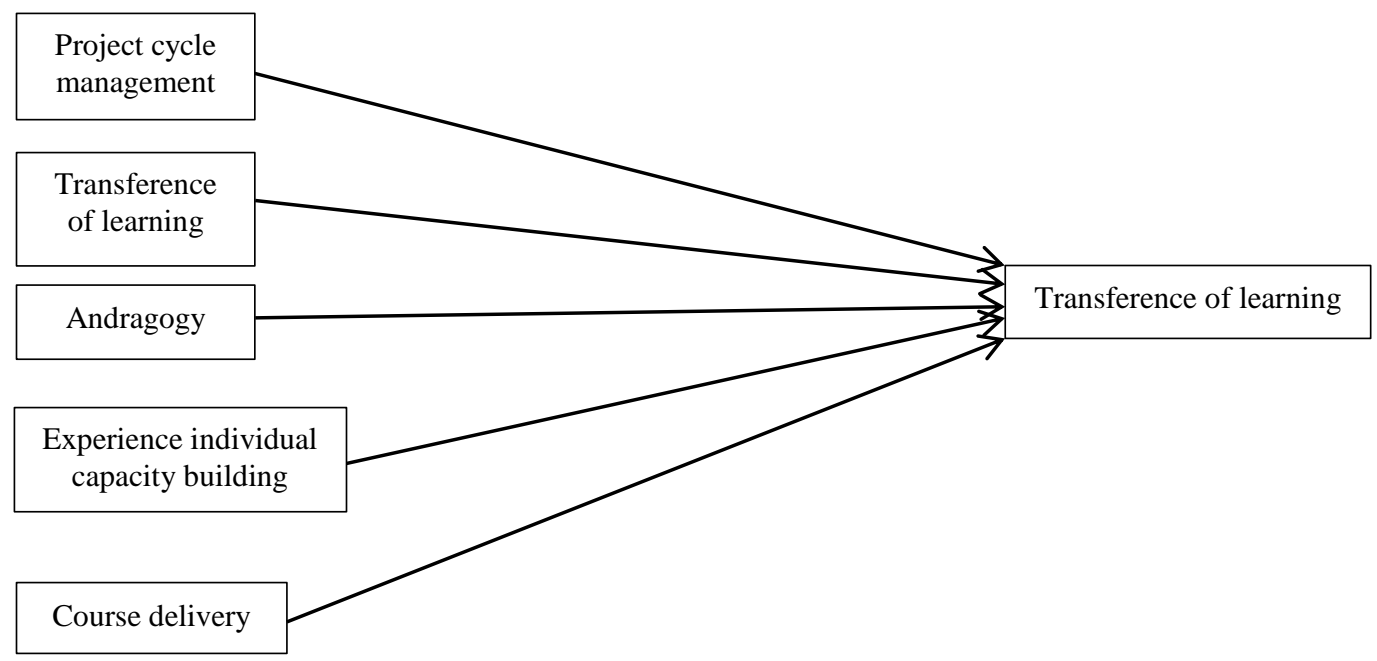

Figure 1 Proposed MIDA Capacity Building Path Analysis Model

\section{Research Method}

Data Analysis

To answer the study's research questions I will use both descriptive and inferential statistical analyses. These analyses were completed through the Statistical Package for the Social Sciences $22\left(\operatorname{SPSS}^{\circledR}\right)$. There are ten research questions for this 
study. Research questions $1 \& 8$ will be analyzed using inferential statistics including Chi-square, and/or Analysis of Variance (ANOVA), Multivariate Analysis of Variance (MANOVA), and path analysis. Research question 2-7 will look at analysis of frequencies, and percentages of the six dependent variables. Research questions 9 and 10 will use thematic analysis to identify results from open-ended items on the questionnaires.

This research study used an explanatory ex-post-facto quantitative methodology using data from alumni of the Master of International Development Administration. Alumni data were collected via survey instruments designed and tested by the author of this dissertation. Due to the off-campus nature of the MIDA program with alumni scattered around the globe, an alphabetical listing of alumni names with active email addresses was obtained from the MIDA International Development Office located on the campus of Andrews University. Survey questionnaires were sent to every name on the list, thus sampling the entire population for this study. This type of sampling, systematic sampling, "can have precision equivalent [to] random sampling” (Creswell, 2014, p. 158).

\section{Delimitations}

The major limitation that this research study has is that not all of the possible MIDA alumni populations were given an equal opportunity to be part of the study. The off-campus MIDA program has been offered in four different languages: English, French, Spanish, and Russian. English and Spanish have been the predominant languages and have produced the largest number of graduates. Because of my language limitation 
(fluent only in English), the survey questionnaires were sent out only to those alumni whose classes were taught in English. Thus the results of this study can be generalized to the English speaking alumni and program. Because the MIDA curriculum is the same in each language in which it is offered, the program leaders and faculty may use expert insight to apply the findings and conclusions of this study indirectly to the MIDA program delivered in the other languages.

\section{Personal Involvement in International Development}

My interest in this research project comes from my own personal involvement in international development. From 1977-79 I was the assistant director of the Seventh-day Adventist World Service (SAWS) "Projet de Irrigation” agriculture/community development project in Chad, Africa. SAWS was the predecessor to ADRA. The director of the project and I worked with Muslim villagers to improve their food security situation in the Sahel region of the country, a region prone to regular drought and famine. My duties: project agronomist, irrigation canal engineer, mechanic, and accountant.

From 1985-92 I was the "Decano," chairperson, for the Faculty of Agronomy for the Dominican Adventist University in the Dominican Republic. This was a new department for the University and I was responsible for forming the curriculum for the program, advising the agronomy students, teaching a full load, and consulting with the agricultural enterprise of the school.

During my seven years at the University I wrote four international development program grant proposals that amounted to about $\$ 870,000$ that were presented to ADRA for funding. These programs benefited the University's academic agronomy program and 
agricultural enterprise. Two of the grant proposals were approved while I was still in the Dominican Republic for which I directed to their completion. The other two program grant proposals were approved after I had left.

The third area of experience within the international development arena was in program evaluation. Twice I was the "head of delegation" for ADRA Central Office to Mozambique, Africa, to do mid-term formative and post-term summative evaluations of an agriculture/community development project. This was followed by my serving as the agronomy specialist for a team of evaluators from ADRA to Ghana, Africa, for a large, multi-faceted community development program that included agro-forestry, education, food security, and water and sanitation.

In my 12 years as an assistant professor in the Department of Agriculture of Andrews University I was also involved with the MIDA program for 5 years as an academic advisor to the African Region. I made yearly trips to the teaching sites to meet with the students on a one-on-one basis. I advised them on different issues that would come up during the time they were within the program and did long-distance communications by way of e-mail during the rest of the year. I had as many as 55 students to advise.

These varied experiences within the international development community for over 30 years have helped me develop to help others to develop. Being involved at many levels in international development has given me a deeper understanding of what real development truly is. 
Personal Philosophy on Development

My personal philosophy about development is as follows: development is not about food security programs, or drilling bore holes to provide clean untainted drinking water, or educational programs, as important as they may be. These are the tools of development. Development's first and ultimate goal is to give opportunities to developing people to help themselves to reach their fullest potential. Ellen G. White (1903) writes in her book Education, "Higher than the highest human thought can reach is God's ideal for His children" (p. 18).

\section{Adventist Development and Relief Agency}

As part of its mission to the world the Seventh-day Adventist Church renders international humanitarian aid through the Adventist Development and Relief Agency (ADRA). The mission of ADRA is twofold: (a) provide short-term assistance and aid to people who are experiencing some form of disaster, whether it be a natural disaster, famine, and war, and (b) manage long-term development projects to help people break the cycle of poverty in which they may find themselves (ADRA International, 2005). Some of these long-term projects may include educational infrastructure assistance, food security projects, maternal-child health education, medical clinics, and water and sanitation. Most if not all the humanitarian work of ADRA occurs in countries that are considered Third World, less developed countries (LDC), or developing countries.

The personnel who work within the ADRA organization come from a wide variety of professional backgrounds and experiences. They include professionals such as teachers, ministers, agronomists, and accountants. The responsibilities for any particular 
individual within ADRA may range from being a project manager or administrator at the grassroots level in a Third World country to being a country or regional director, or working in a First World country to help acquire funds for international development and relief work. The Central Office for ADRA is located in Silver Spring, Maryland, in the United States.

\section{ADRA and Andrews University}

In 1995 ADRA and Andrews University signed a memorandum of understanding (MOU) that Andrews University would develop and provide to academically qualified ADRA employees an off-campus graduate program leading to a Master of International Development Administration (MIDA). The MIDA program was intended to assist ADRA personnel in developing a deeper understanding and working knowledge of what international development entails, in improving the overall efficacy of its employees in project proposal grant writing, and augmenting management skills at all levels within the ADRA organization. This was an overall academic approach to develop capacity building within the organization as a whole (International Development Program, 2014).

Originally the off-campus MIDA program in international development was housed in the Office of the Dean of Affiliations and Extensions of Andrews University. Since the 2011-2012 academic school year the off-campus program has been administered through the Department of Behavioral Sciences in the College of Arts \& Sciences. This department also has on-campus undergraduate and graduate programs in community and international development that were started after the off-campus program began. 
The initial funding for ADRA human resource development, also called capacity building, came from a human resources development educational block grant from The United States Agency for International Development (USAID). These funds for capacity building covered a period of four years. When the USAID-funded four-year period came to an end Andrews University saw the merits of this off-campus MIDA program "to provide a venue for leadership training of professionals whose work responsibilities and life situations do not permit full-time study at a university campus" (Andrews University, 2012, p. 125). Therefore, Andrews University chose to continue the off-campus MIDA program to help achieve part of its own mission of being a change agent through its graduates throughout the world.

The Master of International Development Program

The MIDA program takes five years to complete. Because it is an off-campus academic program the MIDA curriculum program has been taught in different sites near to or within the countries where the students work and live. These teaching sites have been, or are presently located in different countries in Asia, Africa, Central and South America, and Europe. The course work has been delivered in Spanish, French, Russian, and English languages. Each year, over a period of four years, the students journey to a teaching site to take prescribed course work in the language of their choice. Each teaching site usually has 40-60 students, with one site running concurrent programs in English and French in two separate classrooms with different instructors. Intensive instruction is given for two to three weeks, and then the students return to their countries of employment and work to complete post-session projects, and assignments. 
In the fifth year students select and complete a field research project in an area of their interest in consultation with their academic advisor and a concentration research mentor. The students design original research proposals, write literature reviews, collect data, analyze and evaluate the data, and write their findings in a research paper that is of publishable quality. Originally there was a master's thesis option instead of a research project but that option is no longer available because only three students completed theses since the inception of the program. Upon successful completion of all the course requirements students have earned a master's degree in international development from Andrews University.

After its move to the Behavioral Science Department, the mission of the program remained the same: to provide a graduate educational curriculum "to build capacity in leadership" (Andrews University, 2013, p. 123). In 2013 ADRA provided about 100 of the 449 students enrolled in the program, making it the university's largest off-campus program for Andrews University. Over the lifetime of this program the students have come from over 100 countries and over 100 different organizations have been represented in the program. Many of these organizations are like ADRA in that they are nongovernmental organizations (NGOs) and humanitarian agencies, such as World Vision, Catholic Relief Services (CRS), Oxfam International, and small local country NGOs. Also students have come from USAID, government ministries and the private sector. Through the years over 250 students have graduated with their MIDA and 37 have earned a graduate certificate. 


\section{Project Cycle Management}

The International Development Program of Andrews University follows the Project Cycle Management Guidelines (2004), developed by the European Commission, European Aid Cooperation Office (EuroAID), as its model for project cycle management (PCM) instruction. The guideline defines PCM as "a series of activities aimed at bringing about clearly specified objectives within a defined time-period and with a defined budget" (p. 8). The PCM model is used because it serves as a project development and management guide for a wide audience of international development practitioners.

There are six phases within PCM. Specific core courses are associated with each one of the phases (see Figure 2). The first phase, programming, at the regional or national basis, is an analysis to identify problems, limitations, and opportunities which potential development programmes or projects could tackle. Programming requires the study of social and economic factors in order to develop an understanding of the circumstances under which development programmes and project(s) would work, and the issues they would address. This phase of PCM sets up a programming framework of potential project proposals, and identifies prospective donors that could fund the development projects.

The identification phase, the second part of PCM, is to generate project ideas that are in harmony with development priorities expressed in the programming phase. In conjunction with project idea development is to determine the relevance, scope, likely feasibility of projects, classification of key stakeholders, and target groups. Two other aspects are also brought into play in this phase: preparation of financing proposals for individual projects, and incorporating lesson learned from experiences of related ongoing 


\section{Master of International Development Administration (MIDA)}

\section{International Development Core Courses (26 Semester Credits)}

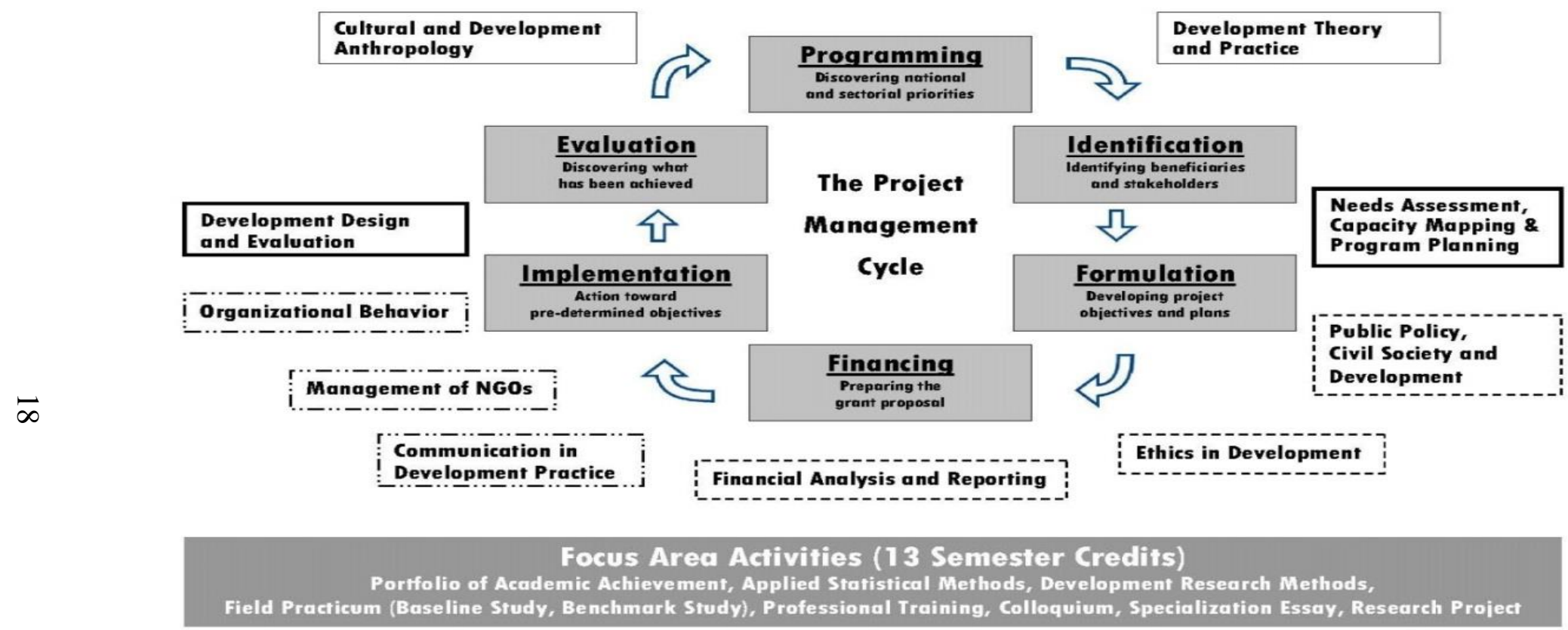

Figure 2. Project cycle management and their relationship to MIDA core courses. From 2015 Student Policy Handbook (p. 23). Prepared by International Development Program, Andrews University, 2014. 
or past projects into the strategy of the present project proposals.

The third phase, formulation, is the detailed written preparation and planning of project proposal(s). The final document for the project proposal several elements will be spelled out. It will state the overall objectives and the purpose of the project and the planned activities to meet those stated objectives. The project proposal will address overall management structure and personal needs, equipment, the locale where the development project(s) would be implemented, financial plan, length of project,

The financial phase is the fourth part of PCM and is an integral and inseparable element of the other five phases. As a separate entity it addresses the total funding needs for the development project(s): how much money will be needed for the project(s), allocation of how, when, and where the funds are to be used, budgeting, and preparation of financial statements in a timely manner. If more than one donor is involved in funding the project(s) this phase includes coordinating the financial responsibility of each donor.

The fifth phase, implementation, is the delivery of the project to the development stakeholders as outlined in the project proposal. It is considered the "most critical" (p. 38) part of the project cycle. All the other stages of the PCM are centered in the implementation and completion of the project. This includes meeting the stated objectives of the project, managing the human and financial resources efficiently and effectively, meeting the expectations of all stakeholders involved, monitoring and reporting the progress throughout the life of the project.

The final phase of PCM is evaluation. This is an ongoing process during the life of the project and possible beyond. There are two parts in the evaluation phase: monitoring and evaluation. Monitoring involves the principal managers reporting the 
progress of the project while it is in its implementation phase. The monitoring reports can be quarterly, semi-annual, and/or annual in nature and are usually sent to the agency that has overall responsibility for the development project (e.g., country office, USAID, SIDA, or ADRA). The monitoring report(s) typically include: documentation of successes and challenges during the implementation of the project, decisions made and justification for those decisions by the project management team, progress in meeting project objectives and goals, and financial reports.

The second part of the evaluation phase is an overall assessment of the project. Usually the evaluation is carried out by a team of independent evaluators who write up a systematic and objective report on the worth and merit of the project. The evaluation process examines every aspect of the project to ascertain the completion of stated objectives, effectiveness, impact, sustainability, and financial veracity.

In its final analysis the evaluation ought to present information that is credible and useful. It talks about lessons learned, unintentional and unforeseen outcomes (both positive and negative) of the project on all the stakeholders: from the recipients of the project, to project management, and donors.

The PCM is a multifaceted, intricate and creative process that calls on the skills of negotiation and communication of individuals to work as a team to formulate and implement a meaningful and well thought out development project. Ultimately the purpose of any international development endeavor is the development of people so they can be contributing members of society.

When the curriculum for the MIDA program was initially developed by Andrews University and ADRA, the PCM served as a central organizing model for capacity 
building in international development. Twenty-six semester credits make up the core courses for the Master of International Development Administration (MIDA) curriculum. Specific core courses are associated with each one of the phases of PCM. In this manner the PCM model becomes an integral part of the educational process in international development (see Figure 2). The original rational for using the PCM model was that all persons who worked within the ADRA network (field office through ADRA International), would have the same fundamental knowledge in developing, managing and evaluating programs and projects so there could be a continuity and teamwork approach within an established framework for international development.

\section{Defining Capacity Building}

Any numbers of definitions can be found for capacity building, and its synonymous term capacity development, in the international development, and NGO communities. Here are a few examples of definitions from the literature of business and the international development community:

1. "The term capacity building refers to the process of strengthening an organization to improve its performance and impact" (Connolly \& Lukas, 2002, p. 7, emphasis in original).

2. "Planned development of (or increase in) knowledge, output rate, management, skills, and other capabilities of an organization through acquisition, incentives, technology and/or training" ("Capacity Building," 2015, p. 1).

3. "Capacity building as the ability of nonprofit organizations to fulfill their mission in an effective manner" (DeVita \& Fleming, 2001, p. 11). 
4. The United Nations Development Programme (2007) understanding of capacity building is "the process through which individuals, organizations and societies obtain, strengthen and maintain capabilities to set and achieve their own development objective over time" (p. 4).

In most of these definitions, and many others like them, the emphasis is on organizational capacity building and very little emphasis on individual capacity building. It is for the individual international development practitioner that Andrews University has developed an educational curriculum to build and increase their capabilities to better serve the organizations by which they are employed, and ultimately all their stakeholders from the donor down through the grassroots level.

For the purpose of this dissertation I define capacity building for the international development practitioner in the context of participation in a graduate educational curriculum in international development. Individual capacity building is the process of developing new skills and critical thinking practices to augment and build on prior learning and professional life experiences. Individual capacity building has the power to improve the work and efficacy of organizations, thus enhancing the dignity and quality of human development, which affect all levels of society. For Crocker and Schwenke (2005) human development is the goal of international development instead of "humans being an instrument of development" (p. 8).

\section{Use of the Term Capacity Building}

The use of the term capacity building or capacity development as a means of people-centered development appeared in the 1980's as an aggregate from other 
development approaches, i.e. human resource development (HRD) or institutional development (Lusthaus et al., 1999). For Morgan (1998, p. 2) it was an "umbrella" of differing concepts which included technical assistance, organizational development, In most of these definitions, and many others like them, the emphasis is on performance, and many others with no defining logic of their relationship.

Since the late 1990's to the present many international development practitioners intuitively believe that capacity building is the way to do development (Lusthaus et al., 1999). The United Nations Development Programme (2013) has taken the position that capacity development is "the way it does business to fit the changing world" (p. 1). To be successful experience has shown that capacity building depends on improving the knowledge and competences of individuals with its effect of transforming the organizations they operate in (de Crombrugghe, 2010).

The ability to learn and be adaptable to situations and changing circumstances is perhaps the most important aspect of capacity building for both the individual, the humanitarian organization (Horton, 1998), and for society. This ability and willingness to learn is what makes capacity building, andragogy, and the transformative learning process, viable and valuable tools in educating the international development practitioner.

\section{Andragogy and the Adult Learner}

One of the areas of human development that has been increasingly studied since the late 1960s is the adult learner, particularly how adults learn, andragogy. Malcolm S. Knowles has been called the "Father of Andragogy" (Knowles, Holton \& Swanson, 2005, p. v) in the United States. Knowles's work focused on the adult as a learner and the 
life situation (Merriam, Cuffarella, \& Baumgartner, 2007). For him, andragogy "meant the art and science of helping adults learn” (Knowles et al., 2005, p. 60) as opposed to pedagogy that dealt with children's learning.

Proposition 1: The principles of andragogy are the basis for the Master of International Development Administration.

Knowles's model for andragogy includes six basic principles. The first principle is that adults need to know why they need to know or learn; however, adults may choose to engage in learning for the pure joy of it. The second principle deals with self-concept. As adults mature they move from being dependent personalities to being more selfdirected, or independent in their choices as human beings. Life experiences are the third principle found in andragogy. As adults go through life, they will accumulate a library or pool of experience, which in themselves are resources for learning. The experiences brought to the learning process tend to be deeper and richer than those possessed by children. The fourth concept of andragogy deals with the readiness (willingness) to learn when adults need to know those things to be able to cope effectively with real-life situations. The fifth principle looks at adults' concept of time. Instead of learning something for future application, more mature adults want to know its immediate application. It also means that adult learners are more interested in problem-solving than subject learning. The last principle of andragogy is that for adults the motivation to learn is more internal than external, as exemplified in workplace learning or continuing one's professional development (Knowles et al., 2005; Merriam et al., 2007). 
The Mystery of Transformational Learning

Coupled with Knowles's work on andragogy is the relatively recent work of Peter Jarvis (2006) who proposed the notion that when adults learn it transforms their whole being. He asserts “the word 'transformation' contains the mystery of human learning, since the bodily sensations of experience have to be transformed into mental meaning by which we explain our personal experience" (p. 22). From the perspective of Jarvis, learning is a holistic phenomenon. He explains this in further detail, noting that individuals are transformed through three dimensions: thinking, feeling, and acting.

Proposition 1: Learning is a process of moving from one steady state to the next. Jarvis illustrates this process of transformation in his book Towards a Comprehensive Theory of Human Learning (see Figure 3). Humans are in a steady state when "our biography is in harmony with our situation" (p. 16). In a steady state, a person is not in a conscious learning mode. However, when "an episodic experience" (p. 17), also called "disjuncture" (p. 16), happens to disturb this biography of harmony then learning can possibly begin. He theorizes that this beginning of learning, depending on the situation, involves any or all of the five human senses: sight, hearing, taste, smell, and touch. Disjuncture can either be rejected or transformed. If rejected the person falls back to the previous biography of harmony and no learning has taken place. If this disjuncture is transformed and internalized into a new "mental meaning" (p. 22), learning has occurred that changes the mind and the body. When this new learning becomes a normal part of a person's biography a new steady state of harmony exists until the next episodic experience occurs. This transformation of experience to learning from an old 


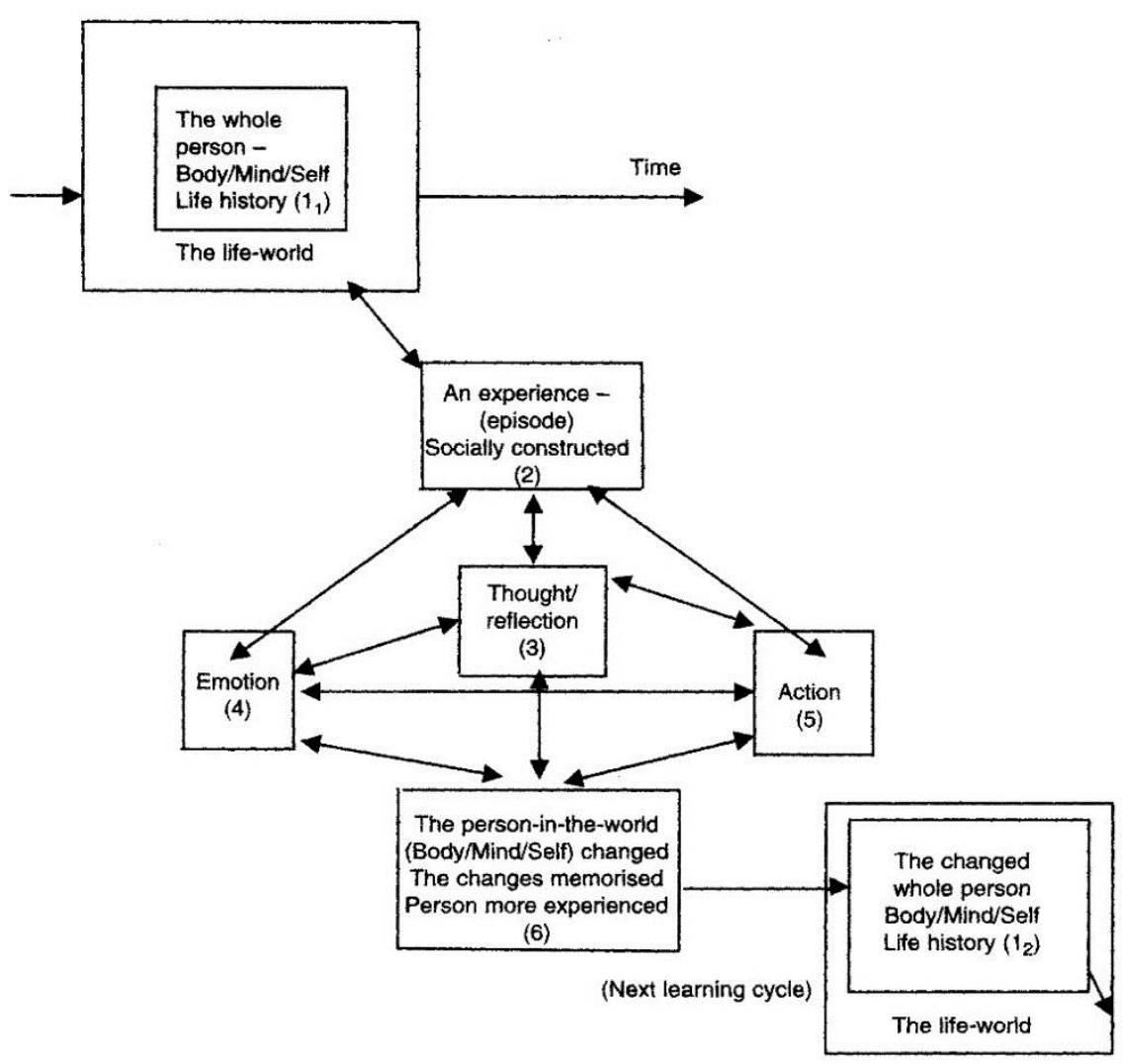

Figure 3. The transformation of the person through learning. From Towards a Comprehensive Theory of Human Understanding: Lifelong Learning and the Learning Society, Volume 1 (p. 23), by P. Jarvis, 2006, London, Routledge. Copyright (2006) by Peter Jarvis. Reprinted by permission.

biography of harmony to a new biography of harmony occurs over time.

Jarvis developed his own model of human learning over a period of about 20 years. In the mid-1980s, dissatisfied with the then present approaches or models being espoused on how human learning occurred, Jarvis developed a research project about human learning that resulted in the publication of his book Adult Learning in the Social Context (1987). Over a period of nine months, 1985-86, adults who were already attending an adult education workshop (nine workshops in total) were to write down their thoughts about a particular incident in their in life where learning had occurred. Then 
they paired up and discussed what they had written. After this initial discussion each pair joined another pair to further discuss their findings on learning. Jarvis then gave each group of four a copy of Kolb's learning cycle $(\rightarrow$ Concrete Experience $\rightarrow$ Reflective Observation $\rightarrow$ Abstract Conceptualization $\rightarrow$ Active Experimentation $\rightarrow)($ p. 8). Each group was told to not necessarily accept Kolb's model at its face value, but to reconstruct it to their own learning experience. Each group of four then reported back to the workshop group their reconstruction of Kolb's learning cycle. In total about 200 persons contributed to this research project about human learning.

The initial model (p. 9) that Jarvis developed for his 1987 publication has gone through several revisions to its present use in Figure 3. Jarvis acknowledges that the works of a number of writers and researchers contributed to his understanding of experiential learning and helped him synthesize the making of his own understanding of the transformation of human learning. They include, among others, John Dewey, who said that life experience contribute to learning (p. 186); Carl Rogers, whose understanding of learning helped individuals become their own real persons (p. 186), Knowles who contributed to theories of andragogy (p. 187); and David Boud and associates (p. 189); with their ideas on how the reflective process has its place in learning.

The thoughts and concepts expressed, as illustrated in Figure 3, embody my own personal and professional reflections on learning. Learning is a dynamic, active, ongoing process that affects a person's whole being. Lusthaus et al (1999) propose that in the learning process, "we begin with what we know and then step into the unknown" (p. 19). 


\section{Outline of the Remainder of the Proposal}

Chapter 2 explores ideas and issues pertaining to capacity building and international development. It is organized in the following manner: (a) an overview of international development and how it is defined, (b) different methods that organizations use to try and build capacity in their employees, (c) the use of an education as an instrument of capacity building for the international development practitioner, (d) the World Bank's experience in capacity building education, and (e) the use of alumni surveys in research.

Chapter 3, describes the research design used, defines who the subjects are and from whom the data was collected, the data collection instrument used and how it was developed, its distribution, the data collection process, hypotheses statements and testing, and how the data was statistically processed and displayed.

Chapter 4, presents the demographic analysis of the respondents, inferential statistical analysis of the different study variables, multiple linear regression, and path analysis of the combination of the independent variables, and thematic analysis to the open-ended questions.

Chapter 5, talks about an overview of the what this research study is about, it presents a brief summary of the literature review that is relevant to the findings of the study, a discussion about the study findings and their importance in the area of international development education in capacity building for the MIDA alumni, grounded theory and theoretical framework development, and concludes with what further followup research could be carried out to understand the capacity building influence the MIDA 
alumni could have on the international community in the work setting, and society they are trying to serve. 


\section{CHAPTER 2}

\section{LITERATURE REVIEW}

\section{International Development Overview}

The concept of international development is that developed countries, known as donor countries, help developing countries out of poverty and raise their standard of living (Food and Agriculture Organization, 2008). Even though international relations and trade have existed for hundreds of years only in the last half of the $20^{\text {th }}$ century and into the present century has international development been called the "era of development" (Thomas, 2000, p. 5).

Many believe the starting point of "development planning” (Willis, 2005, p. 38) for this era of development began on January 20, 1949, when the U.S. President Harry S. Truman, in his presidential inaugural address, made the following comments:

We must embark on a bold new program for making the benefits of our scientific advances and industrial progress available for the improvement and growth of underdeveloped areas. More than half the people of the world are living in conditions approaching misery. Their food is inadequate. They are victims of disease. Their economic life is primitive and stagnant. Their poverty is a handicap and a threat both to them and to more prosperous areas. For the first time in history, humanity possesses the knowledge and the skill to relieve the suffering of these people. (p. 4) 


\section{Defining International Development}

The phrase "international development" is sometimes difficult to define, because it is wide-ranging in what it is trying to accomplish, its purpose, the various disciplines involved, and its endeavor to improve the quality of people's lives from place to place, and from situation to situation around the world (Greiman, 2011). International development can be defined in terms of being holistic and multi-disciplinary in the framework of human development (Rosenkranz, 2011).

The word development implies growth, progress, change, or improvement in the human condition. Because of their own attributes of development human beings are multi-dimensional in their developmental process: socially, physically, emotionally, mentally (Santrock, 1992), and spiritually (White, 1903). International development is therefore linked within the framework of human development that encompasses economic and social advancement that are humanitarian in its actions. These actions could include education, food and water security, public health, poverty reduction, gender equality, capacity building, and self-governance (Greiman, 2011).

Projects associated with international development can be singular or multifaceted in nature. Singular projects tackle a specific problem or situation, for example: HIV/AIDS prevention educational program, home vegetable gardening to improve family nutrition and income, or polio vaccinations to prevent polio. Multifaceted projects are several projects in a defined geographic region that are consolidated under one management umbrella, but speak to several issues within a society or culture. For example: a community development project that includes, primary education, HIV/AIDS prevention, and agroforestry projects. Most of these projects are mid-term to long-term in 
length (three to five years), should be sustainable, and under local management or control after funding has stopped (US Legal, 2014).

\section{Development Organizations}

Within the international community there are a number of means by which development funds and aid can be delivered. At the highest levels are international development organizations that are major donors, planners, and providers of financial support for development work to come about. Some of these organizations are directly connected with a developed country's government. The largest governmental sponsored agency that supports international development is the United States Agency for International Development (USAID) (Greiman, 2011). The budget for this agency in 2014 was 20.4 billion dollars, which was involved in development and humanitarian assistance in more than 100 countries (USAID, 2014a). Other developed countries have similar government sponsored programs to offer aid in the international development community. Examples include: Swedish International Development Agency (SIDA), Danish International Development Agency (DANIDA), Japan International Cooperation Agency (JICA), and Norwegian Agency for Development Cooperation (NORAD).

The World Bank (2014) is another major international development organization that provides a "vital source of financial and technical assistance to developing countries around the world" (p. 1). They provide a wide array of low-interest loans, interest-free credits, and grants to developing countries. These funds aid in a wide array of investment projects in areas such as education, health, public administration, infrastructure, financial and private sector development, agriculture, and environmental and natural resource 
management.

Within the last 25 to 30 years, non-governmental organizations (NGOs) have become major participants in the "landscape of international development" (Lewis, 2009, p. 1). NGOs are non-profit, non-sectarian, and for the most part independent of any particular government (United Nations, 2014). According to the UN the number of and types of organizations that are of a consultative status with the UN which are engaged in humanitarian relief and development work has increased dramatically. In 1946 there were 41 such UN recognized organizations while in 2012 there were over 3,400 (Department of Economic and Social Affairs, 2013). NGOs control over 15\% of development funds that are expended overseas (Greiman, 2011). Donors that provide monetary support for NGOs may be individuals, corporate foundations, or government sponsored humanitarian development and relief agencies in First World donor countries.

The efforts of NGOs are powered by a variety of values and motivations. There are both secular and faith-based organizations that try to meet the needs of the people (Lewis, 2009). Some of these organizations started out doing short-term relief work but have evolved into development work at the international level.

Catholic Relief Services (CRS) is an example of a faith-based NGO organization. It is the official international relief and development humanitarian agency of the U.S. Catholic Church community. It was founded by the U. S. Conference of Catholic Bishops in 1943 to help with the burgeoning humanitarian refugee crisis of war-torn Europe during and following WWII. Even though their initial work began as a response to providing relief in an emergency situation, over the decades it has evolved into helping people in developing countries through long-term community-based development 
projects to help break the poverty cycle.

The mission of CRS is to help poor and disenfranchised people outside the United States, to promote the sacredness and dignity of human life, while, "working in the spirit of Catholic Social Teaching without regard to religious affiliation, gender, or political viewpoint. All of the activities of the CRS are motivated by the Gospel of Jesus Christ to help alleviate human suffering and the development of people with charity and justice" (p. 1). CRS works in over 100 countries in emergency relief, health, agriculture, education, HIV/AIDS awareness programs, and peace building. In 2011 over $95 \%$ of CRS revenues were directly used in overseas projects that benefitted the poor (Catholic Relief Services, 2011).

The world's largest secular NGO, Bangladesh Rural Advancement Committee (BRAC, 2013) was rated as the number one NGO for 2013 by The Global Journal (2013). BRAC could be speaking for many NGOs and their approach to development, when they write that they are "dedicated to alleviate poverty by empowering the poor and helping them to bring about positive changes in their own lives by creating opportunities for the poor" (BRAC, 2015).

\section{International Development Terminology}

A sidebar discussion of terminology that is often used within and about the international development community needs to be addressed that is used to categorize nations or regions based upon economic, political or cultural standing. The French writer Alfred Sauvy coined the phrase "le tiers monde" (Third World, 2013, p. 1) or Third World in the 1950s. This phrase was used to describe the poorest non-aligned former 
colonial nations in Asia, Africa, and Latin America. The phrase Third World was to distinguish them from the post WWII Cold War era (1945-89) stand-off nations of the United States and its Western European Allies, the First World, versus the Eastern European communist economic states that aligned themselves with the USSR, the Second World (Third Word, 2013).

With the breakup of the USSR in the late 1980s and early 1990s and the domino effect of Eastern European communist economic states falling away from their former allies, the phrase Third World has been looked upon with disfavor in some circles because of its ethnocentric bias (Oregon State University, 2012), but it is still a common term, even within the UN. Other commonly used terms found in popular and professional literature to describe these former non-aligned countries include "developing countries," "less developed countries" (LDC), or "underdeveloped countries."

\section{Education and Capacity Building}

One of the $20^{\text {th }}$ century's most prolific writers and highly regarded business consultants, Peter Drucker, makes the following statement "The basic economic resource - 'the means of production' ... is no longer capital, nor natural resources, nor labor, it is and will be knowledge” (1993, p. 8; emphasis in original). Hans Van Ginkel, the Rector of the United Nations University, basically says the same thing, globalization and the work or capital intensive economy is being replaced by "knowledge-intensive economy" (Van Velzen, 2013, p. xxii; emphasis in original). The Office for Economic CoOperation and Development (OECD) emphasize knowledge "as an asset or a commodity" (2001, p. 13). The use of knowledge is to benefit society, especially in the 
arena of international development (Crossley \& Holmes, 2001). This acquisition of knowledge can be presented in several formats or curriculums, and settings to aid in its distribution.

\section{Capacity Building Opportunities in International Development}

\section{On-the-Job Training Experience}

As Figure 4 shows, there are two basic tracks that international development practitioners can follow to build capacity for themselves and the organization they are employed by. In some cases the practitioner may have participated in both of these tracks in their international development professional career. In the first track, within the organization, the capacity development program is handled as the heading suggests within the organization. Through the work experience process, on-the-job-training (OJT), individuals may learn about certain aspects of international development as it applies to their own professional areas (education, agriculture, business management, and health) but there is no coherent overarching system in place for them to understand the holistic concepts and principles of the what and how of the international development community.

\section{Internship Experience}

A second area within an organization where capacity building could occur is through an internship program. The internship program is where an individual comes into an organization for a few months to a year to learn about the workings of the international development community. Interns are usually current students or recent graduate's from a 
college or university that would like to gain some international development experience before they set out in their own professional career. During the time of their internship they work to gain experience in several areas within the organization and to acquire an overview of the work of an international development agency.

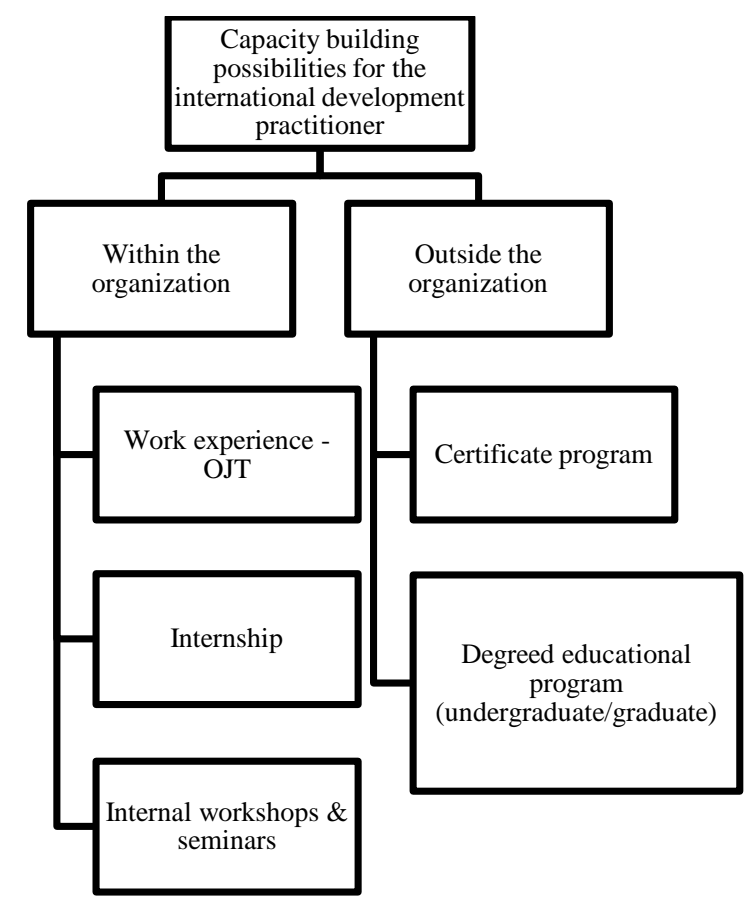

Figure 4. Capacity building opportunities.

Most internship programs are quite structured that gives day-to-day hands-on practical experience in humanitarian related work that the intern possibly cannot be experienced otherwise. The intern is expected to perform at a certain level of professionalism to not only learn the day-to day operations of the organization but to also contribute to the overall mission of the organization and agency.

ADRA has two internship programs. The first is a short-term internship of three 
months in duration at 20-38 hours per week that takes place at the ADRA International headquarters in Silver Spring, Maryland. The requirements for prospective interns are that they must be currently enrolled in an accredited graduate program in some level with a humanitarian aspect, such as international development, disaster response, or project management, be a US citizen, Green Card holder or have a current work permit for the US. Preference is given to students with strong academic achievement, previous international field experience, and who is a member in good standing with the Seventhday Adventist Church. The intern will have to be self-supporting in regards to housing, transportation, health care, and there is no stipend.

The second internship opportunity through ADRA is one year in length. The intern must have already graduated from a graduate level (master's) degree program or higher and have an interest in pursuing a career in international development. There is a one month orientation period at ADRA headquarters. Depending upon the intern's interests, and ADRA's perceived learning experience needs for the intern, they will spend a week each in different areas: finance, marketing, disaster relief, project development, and project grantwriting. Then the intern will spend nine months in an overseas ADRA office either in Asia, Africa, or Latin America. There is a two-month follow-up and debriefing period back at ADRA International. There may be a small stipend and housing assistance while in the field, and some financial aid for international travel. If the prospective intern is reasonably comfortable in a second language, has had 12 months or more of previous international field experience, and is a member in good standing with the Seventh-day Adventist Church he or she will be given preferential treatment in consideration by ADRA for this internship program (ADRA International, 2013). 
Another example of an organization that offers internship opportunities is Save the Children. One internship program is an unpaid position with no housing benefits. An intern in this program must be eligible to work in the US, be actively enrolled as an undergraduate or graduate student, and must be able to receive academic credit from their college or institution for their internship experience. The intern works a minimum of 1520 hours per week with a maximum of 38 hours per week.

For those students who are highly qualified but cannot participate as an unpaid intern due to financial constraints there is the Save the Children Diversity Intern Scholarship program. The prospective intern must be a junior or senior in an accredited academic institution or enrolled in a graduate program. They must be highly motivated with proven academic and leadership abilities, and have a background in working in a diverse community. The interns for this program will receive a monthly stipend of $\$ 1,200$ per month during the spring, summer and fall semesters. They will also receive academic credit as in the unpaid internship program (Save the Children, 2013).

Neither organization promises employment after the internship period is over. But if the intern has had a positive experience it can go unto their resume as a reference point in their career, and possibly help them obtain a position in a humanitarian organization they would seek employment from.

\section{In-service Workshops or Seminars}

The third possible way for an organization to build its own capacity from within is to have demand-driven in-service workshops or seminars to train the staff on a specific 
topic or when a felt need becomes apparent to the organizations. Most of these in-service meetings are usually short-term events that may last for two days to a week or more in length. Sometimes these in-service educational seminars will involve the entire staff, or selected staff, such as proposal grantwriting or project management and implementation, or they may be just for administrators. For the most part there seems to be no interconnectedness between the different in-service meetings in trying to present a unified understanding of the work of international development.

\section{Education}

The second track for capacity building in Figure 4 is through an academic curriculum that is offered by an educational institution. This kind of endeavor can lead to either a certificate in some aspect of international development or a degreed undergraduate or graduate program that is specifically geared to the study of international development. This is the kind of programs that Andrews University offers. The oncampus program has both undergraduate and graduate degrees, and graduate certificate program in international development. The off-campus program offers a graduate degree in international development (MIDA) and two graduate certificate programs in international development and organizational leadership (Andrews University, 2012).

\section{Cross Border Education}

One of the settings this dissertation discusses is the concept of taking a capacity building educational curriculum to the student, cross-border education (Knight, 2006) . This type of educational outreach is carried out by Andrews University to aid professional international development practitioners to be more effective and efficient in 
building capacity for themselves, the organization for whom they are employed for, and ultimately the clients they are serving.

A phrase that is sometimes used in higher education circles to describe education for the international student is "crossborder education." Knight delineates this term as "the movement of education (students, researchers, professors, learning materials, programmes, providers, knowledge, and so on) across national/regional jurisdiction or geographic borders" (Knight, 2006, p. 104). Andrews University is doing "crossborder education" through its off-campus international development graduate program.

MIDA graduate students cross international borders to attend classes at an offcampus teaching site. Professors and lecturers make the journey from Andrews University, or adjunct professors from other institutions and organizations, to the offcampus teaching sites to deliver the course curriculum to the students. Learning materials, sometimes in the form of course modules, have been prepared at the mother institution and are distributed to the students. The MIDA curriculum, which was put together at Andrews University by a curriculum team, is implemented. In the fullest since of the phrase "crossborder education" the MIDA program meets these criteria.

When the formal course work is over for a particular course the students return to their home countries crossborder education continues, but this time in the reverse. The student's post-session assignments are submitted to course instructors for evaluation and grading, usually through e-mail submission.

In the truest sense of the term "crossborder education" is a two lane highway that is very wide in its scope. The institution delivers knowledge and learning through its professors to the students. The students take this newly acquired knowledge and learning 
and immediately apply it in the real world in which they live and work. By this application of knowledge and learning, and through the insights of applied research, new knowledge is generated. The student returns this new experiential knowledge and the lessons learned through the written academic papers and the instructors now become recipients of new knowledge from their own students. The institution is made academically stronger by the knowledge of their students who have learned, and built capacity that strengthens themselves and the organizations they work for.

\section{Effects of Capacity Building}

Figure 5 exhibits the ripple effect throughout the international development community (Connolly \& Lukas, 2002; de Crombrugghe, 2010) because of a capacity building program to an individual international development practitioner. The whole international community is affected by such a program from the individual who partook in the capacity building program and then transfers their learning through their work in an international development organization through donor funded development projects to the community and finally at the grassroots level of the individual client. "Capacity development (building) is ultimately about people" (United Nations Development Program, 2010b, p. 4).

Also the donor(s) are better served by getting more effiency from the development monies that are being invested into the humanitarian organization and its projects. The skills and critical thinking process learned in a capacity build program the international development practitioner is able to write project grant proposal(s) that are more coherent with logical intended outcomes. Also, after a project is funded by a donor 
the projects are managed at a higher level of professionalism and accoutability.

These two figures (Figure $4 \&$ Figure 5), taken as a whole, demonstrate that capacity building is an interlinking and interdependent holistic process at the individual, organizational, and societal levels (Lewis, 2008; Jarvis, 2006; Sessions, 1993; United Nations Development Programme, 2007). "[T]he individual is essentially linked to the destiny of the larger community" (Andrews Study Bible, p. 614, 2010).

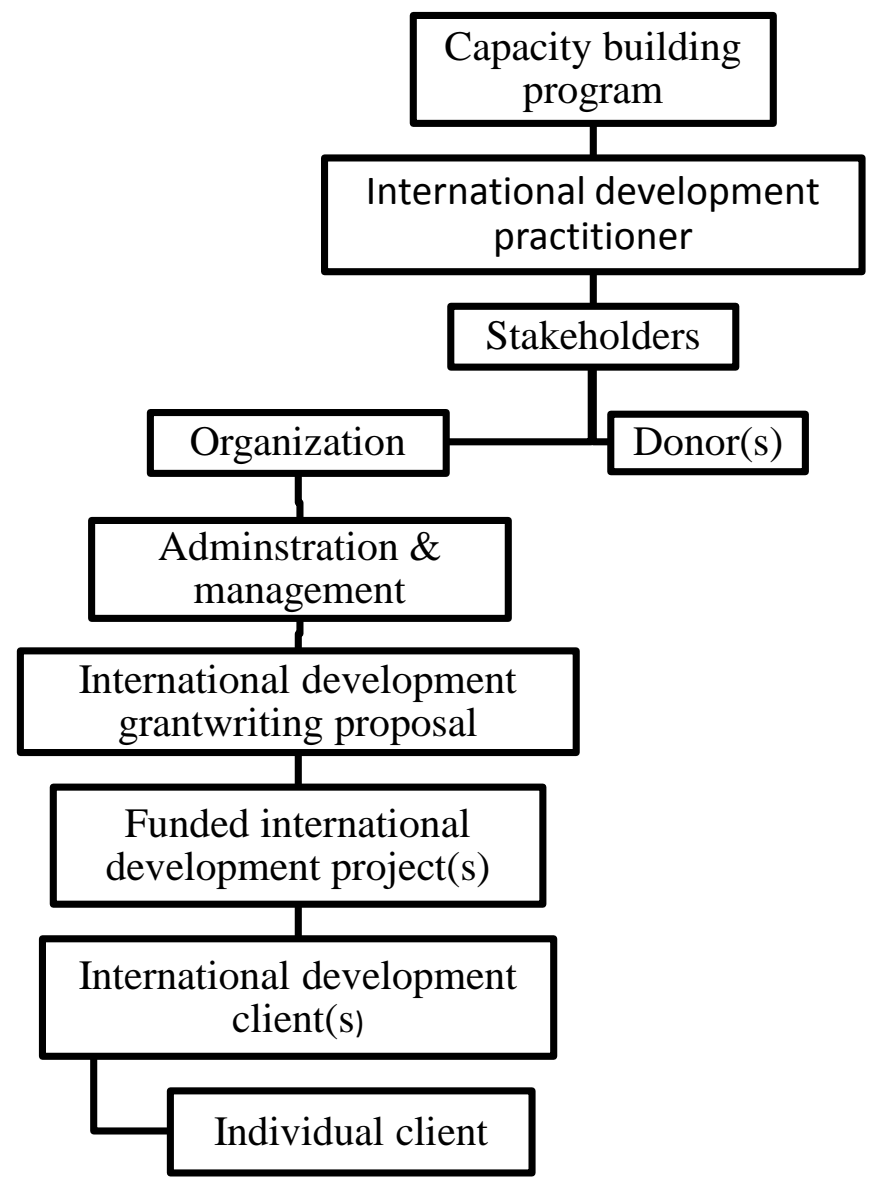

Figure 5. Capacity building ripple effect. 
Capacity building at any one level can have results and impact on all levels up or down the international development community.

\section{Effectiveness of Capacity Building}

The primary goal of capacity building in the international development arena is to foster sustainable development. The success or effectiveness of capacity building is difficult to monitor because "it is a soft target ... to quantify" (UNEP, 2006, p. 6). The World Bank (Chin, 2008) supports and finances annually about $\$ 720$ million in client capacity building projects to help reduce poverty in developing countries. The aspirations of these capacity building initiatives are three fold: build skills among individuals in performing development tasks, improve the organizations they are employed by in meeting their stated development mission, and strengthen the society they are playing a part in. While it found that most financed training lead to improved individual learning, the World Bank's goal to build capacity at the organizational level to improve overall agency performance or capacity improvement was effective about half the time. Their assessment about capacity building training is "Individual learning results are poor predictors of enhanced workplace performance" (Chin, 2008, p. 11).

The Word Bank thinks that where capacity building learning has failed to change workplace operations and have an impact on development as a whole fall under three main areas: (a) individual understanding how to practically apply capacity building principles to the workplace, (b) the organization not providing resources or encouragement for implementation of capacity building principles, or (c) insufficient targeting of capacity learning to institutional needs. Therefore, two questions that need to 
be addressed in the transference of learning of capacity building principles "How can the individual learning process in capacity building be improved to build strong and effective institutional capacity?" and "How can an organization incorporate capacity building learned by an individual as its own?"

There are a number of methods to build capacity, which includes: short-term training seminars or workshops, networking, formal education, and capacity building projects (UNEP, 2006). Whatever method(s) are used capacity building is a long term commitment that takes time to accomplish, "time measured in years" (Wing, 2004, p. 157).

In its study, Using Training to Build Capacity for Development (Chin, 2008), the World Bank determined the importance of the training process. For them "good training design is important for success along the entire length of the training results chain" (Chin, 2008, p. 21). The first of the design factors was to have good pedagogy. This encompassed professionally designed curriculum tailored to meet training needs, and the use of various didactic teaching methods which were applicable to meet training goals. Secondly, support for the transference of learning to the workplace. This involved inclass action-learning and practical exercises to smooth the process of implementation of capacity building lessons learned to the workplace. Coupled with this was the idea of follow-up support for further on-the-job training. The third design factor was targeting of training to meet organizational needs. This factor comprised of carrying out a capacity diagnosis of the organization, a training needs assessment, and planned selection of who should be trained to best meet organizational goals.

The World Bank has a division that organizes and delivers capacity training 
programs. This division is the World Bank Institute (WBI). Annually WBI presents about 700 programs in capacity building that involves around 80,000 participants. In 2007 WBI conducted a survey for its evaluation of the training programs. The survey performed face-to-face and telephone interviews with 548 randomly selected persons from six countries who were involved in the training programs from 2004-2006.

The participants were asked about the importance of training processes and background factors to training success. They were asked a number of agree or disagree statements to determine their perception of course attributes. From this the evaluation team was able to determine the predictive course attributes to formulate what they call "drivers of program success" (p. 71) (see Table 1.) The evaluation found that stronger the predictive power of course attributes the higher of importance in the opinion of the participants was the driver overall.

From this study it was shown that for capacity building programs to be effective the course(s) needs be pedagogically strong and well organized. The course work should meet the practical side of capacity building development needs of the participants. Also, the organizations the participants are employed by need to be encouraging and supportive of the capacity building activities that were learned, and implement lessons learned by the individual to their organization. Through educational capacity building programs to the individual, organizations can build their own capacity from within, which in the long run builds the capacity of the society they are trying to serve and develop. 
Table 1

Drivers of Program Success

Driver

- Course targeting

- Course quality

- Participant input/feedback

- Participant mix/interaction

- Practical learning

- Course time allocation

- Organizational support

- Material resources at workplace

- Instructor follow-up

- Participant follow-up
Correlated survey statement

The level of the course was appropriate for a person with my knowledge and experience. The course specifically addressed my countries circumstances.

The course content address issues that are important to my work.

The lectures were of good quality.

The course content was interesting.

The course was in a language I am fluent in.

I was given the opportunity to provide feedback on my satisfaction with the course. The course organizers asked me to share with them my needs or objectives in the course, either before or at its start.

Course participants had about equal levels of knowledge/experience coming into the course.

I learned from the experience of other participants in the course.

I was given course materials (schedule and/or course materials) before the course start date.

The course devotes significant time to practical exercises or projects.

The course covered the right amount of topics for the amount of time allotted.

My colleagues provided me with the support I need to apply what I learned in the course.

My managers encourage my efforts to use what I learned in the course.

I have the resources (for example, equipment, software) to apply what I have learned.

Communication with course instructor (either on line or 'other').

Communication with course participants (either online or 'other').

From Using Training to Build Capacity for Development: An Evaluation of the World Bank's Project-Based and Training WBI (p. 22), edited by H. Chin, 2008. Washington, DC: The World Bank. 


\section{The Use of Alumni Surveys in Academia}

The use of alumni surveys in the United States by colleges and universities dates back to the 1930s. These surveys dealt mainly with workforce issues: job satisfaction, and transition from academic to the workforce life (Cabrera, Weerts, \& Zulick, 2005). Since the 1980s these surveys have expanded their focus beyond alumni post-graduate out comes to investigate direct assessment of student learning, and the influence of institutions may have had on developing critical thinking skills, interpersonal communication, and vocational skills (Borden, 2005; Cabrera et al., 2005; Ewell, 2005). Another aspect the use of surveys was trying to measure is "assessing the knowledge, skill, and abilities that connect the academy to the world of work" (Hoey \& Gardner, 1999, p. 44). By surveying alumni and employers it assesses the knowledge and skills obtained by the graduate from the institution for evaluating the relevance of the academic curricula to the changing needs, demands, and expectations of the profession (Hoey \& Gardner, 1999). 


\section{CHAPTER 3}

\section{METHODOLOGY}

\section{The Research Design and Subjects Defined}

The investigator talks about the research design used, defines who the subjects are and from whom the data were collected, the data collection instrument used, how it was developed and its distribution, the data collection process, and how the data were statistically processed and displayed.

The research design used in this investigation is an explanatory ex-post-facto quantitative methodology design. Ex-post-facto is used to explore possible causal relationship(s) after the event(s) has happened. The variable(s) or the event(s) cannot be manipulated by the researcher (Newman, Benz, Weis, \& McNeil, 1997). There are elements of both quantitative and qualitative data within the research process. Quantitative data are empirical and objective in nature that can be statistically analyzed, while qualitative collects subjective non-numerical data, and is exploratory in purpose. It gives the respondents the opportunity to express their feeling, thoughts, and their ideas that is more personal in both depth and breadth (Van Velzen, 2013) without the strictures of the quantitative process.

\section{Study Population}

The population for this study consisted of alumni of the Andrews University offcampus Master of International Development Administration program. As this program 
was offered in four languages, the study population for the current study was delimited to those alumni who took there course work in English. A minimum response rate of $10 \%$ was needed to conduct a valid path analysis.

\section{Study Variables and Null Hypotheses}

The dependent variable for this study is the transformation of the MIDA alumni as a result of participating in the program. There are two conditions that are related to the dependent variable: latent and observable. Inherent in the dependent latent variable is the concept of trying to explain, to understand, and sometimes predict actions that are not “directly observable" (Bollen, 2002, p. 605). These understandings are deduced or inferred through the use of dependent variables that can be observed and measured in some way. Table 2, indicates that there is one latent dependent variable: transformation of MIDA alumni. This list also shows that the latent dependent variable is measured through one dependent observable variable: alumni perceptions of experiencing individual capacity building, coupled with the dependent variables are independent variables. Independent variables are the variables that the researcher has control over or can manipulate in regard to the dependent variables. Generally, researchers anticipate the independent variable(s) will have some effect, impact on, or relationship to the dependent variable(s) (Brigham Young University, 2015). There are five independent variables shown in Table 2: (a) MIDA alumni perceptions of using project cycle management to organize the MIDA curriculum, (b) MIDA alumni perceptions of effectiveness of course delivery, (c) MIDA alumni perception of andragogy, (d) MIDA alumni perceptions of transformative learning, (e) MIDA alumni perceptions of transference of learning on the 
mission and work of their employing agency.

The third type of variable shown in Table 2 is the classification variable, sometimes called categorical variables. This type of variable is usually independent and based upon some characteristic (i.e., gender, marital status, academic level in school, age), and are given a discrete value that usually cannot be added, subtracted, multiplied or divided. The qualitative values can either be nominal, ordinal, or dichotomous

Table 2

Variable Types, Variable Names and Operational Definitions

\begin{tabular}{|c|c|c|}
\hline Variable Type & Variable Name & $\begin{array}{l}\text { Operational Definition } \\
\quad \text { (Survey Items) }\end{array}$ \\
\hline Dependent - Latent & Transformation of MIDA Alumni & \\
\hline $\begin{array}{l}\text { Dependent - } \\
\text { Observable }\end{array}$ & $\begin{array}{l}\text { Alumni Perceptions of Development } \\
\text { of Individual Capacity Building }\end{array}$ & $42 \mathrm{a}-\mathrm{g}$ \\
\hline \multirow{11}{*}{ Independent } & $\begin{array}{l}\text { MIDA Alumni Perceptions of Using } \\
\text { Project Cycle Management to } \\
\text { Organize the MIDA Curriculum }\end{array}$ & 43 a-g, 44a-e, \& 45 \\
\hline & $\begin{array}{c}\text { MIDA Alumni Perceptions of } \\
\text { Effectiveness of Course Delivery }\end{array}$ & $17-39$ \\
\hline & $\begin{array}{l}\text { MIDA Alumni Perception of } \\
\text { Andragogy }\end{array}$ & $46 a-j$ \\
\hline & $\begin{array}{l}\text { MIDA Alumni Perceptions of } \\
\text { Learning Theory }\end{array}$ & $47 a-j$ \\
\hline & $\begin{array}{c}\text { MIDA Alumni Perceptions of } \\
\text { Impact on the Mission and Work of } \\
\text { Their Employing Agency }\end{array}$ & $40 \mathrm{a}-\mathrm{i}, 48,49,50 \& 51$ \\
\hline & Present Age - Alumni & 4 \\
\hline & Undergraduate Degree -Alumni & 5 \\
\hline & $\begin{array}{c}\text { Other academic/professional degrees } \\
- \text { Alumni }\end{array}$ & 6 \\
\hline & MIDA Beginning Year - Alumni & 7 \\
\hline & $\begin{array}{c}\text { Year Attended Last Session - } \\
\text { Alumni }\end{array}$ & 8 \\
\hline & Year of Graduation - Alumni & 9 \\
\hline
\end{tabular}


Table 2-Continued

\begin{tabular}{|c|c|c|}
\hline $\begin{array}{c}\text { Classification } \\
\text { (Demographic) }\end{array}$ & Variable Name & $\begin{array}{c}\text { Operational Definition } \\
\text { (Survey Items) }\end{array}$ \\
\hline \multirow{4}{*}{ Variable Type } & Years to Complete MIDA & $\begin{array}{c}\text { Calculated from items 7 } \\
\& 9\end{array}$ \\
\hline \multirow{5}{*}{} & Age at Time of Graduation & 10 \\
\hline & $\begin{array}{c}\text { Type of Organization at the } \\
\text { Beginning of MIDA Program }\end{array}$ & 11 \\
\hline \multirow{5}{*}{} & Type of Organization Work for Now & 12 \\
\hline \multirow{5y}{*}{} & Job Title & 13 \\
\cline { 2 - 3 } & Job Responsibilities & 14 \\
\cline { 2 - 3 } & Application Process & 15 \\
\cline { 2 - 3 } & Communication With MIDA Office & 16 \\
\cline { 2 - 3 } & Recommend to Someone Else & 41 \\
\hline
\end{tabular}

(UNESCO, 2015). There are 31 classification independent variables used in this research study.

\section{Null Hypotheses}

The use of a null hypothesis statement is the "traditional approach" (Cresswell, 2014, p. 144) in predicting that there is no relationship or statistical difference of the means of two groups on a variable in the general population (Cresswell, 2014, McMillan \& Schumacher, 2001). To be able to test the null hypothesis an inferential statistical test is employed to resolve the probability that it is untrue. If it is determined that a null hypothesis is false there is a high probability that there is a statistical difference between the variables being measured (McMillan \& Schumacher, 2001). 
Two of the 10 research questions that guided the data analysis for this study required inferential statistical analysis to answer. Those analyses were guided by the

following null hypotheses.

Research Question 1. Do differences exist by gender and present age in MIDA alumni perceptions of experiencing individual capacity building, course delivery, project cycle management, andragogy, transformative learning, and transference of learning.

$H_{0}$ 1: There are no statistically significant differences by gender and present age in MIDA alumni perceptions of experiencing individual capacity building, course delivery, project cycle management, andragogy, transformative learning, and transference of learning.

Research Question 8: Are project cycle management, transformative learning, andragogy, course delivery, significant predictors of transference of learning mediated by experiencing individual capacity building to their organization?

$H_{0}$ 2: Project cycle management, transformative learning, andragogy, course delivery, are not significant predictors of transference of learning mediated by experiencing individual capacity building to their organization.

\section{Instrumentation}

A data collection survey instrument were used in this study and developed by the primary investigator (see Appendix B). The Alumni Survey used three different means of obtaining information from the respondents: (a) Demographic questions, (b) 5-point Likert-type scale that covered their thoughts, attitudes, opinions, and feelings dealing 
with course delivery, project cycle management, andragogy, transformative learning, experiencing individual capacity building, and transference of learning; (c) two openended questions gave the respondents an opportunity to answer the questions in a subjective and a personal manner that the other two ways did not afford that were related to the strengths and challenges of the MIDA curriculum, the benefits of the MIDA capacity building program to the international development community, and important concepts and principles they alumni thought were important.

The survey instrument was developed by the writer of this dissertation with consultation from his three member dissertation committee. It was then pre-tested by sending it to persons who were involved in international development academically, and with field experience. Finally pilot surveys were sent to on-campus alumni of the international development graduate program of Andrews University. This pre-testing procedure helped the primary investigator work out any issues with the formatting of the survey instruments, the questions being asked, any suggestions on other questions or information that needed to be asked, and the level of difficulty or ease of filling out the survey. The survey itself took approximately 15-20 minutes to complete.

\section{Procedures}

\section{Data Collection}

A cover letter was written to accompany the surveys that explained the purpose of the research that was being conducted (See Appendix B). No financial remuneration was promised to the respondents, and all answers to the questions would be held at the highest level of confidence and anonymity. 
Due to the nature of the off-campus program in international development the MIDA alumni are scattered throughout the world, living in a number of countries and working for different organizations. Therefore to maximize the response rate the cover letter and survey were sent out as an e-mail to the alumni of the program. A total of 307 e-mail addresses of the alumni were obtained from the off-campus International Development Office located on the campus of Andrews University. Of this number when the emails were sent out requesting the MIDA alumni to participate in the survey 172 (56\%) were deliverable and $135(44 \%)$ were undeliverable. Using social media Facebook ${ }^{\circledR}$ and Linked-In ${ }^{\circledR}$ to search for alumni who had undeliverable email address I was able to obtain current email addresses on 35 of the MIDA alumni. This brought the total survey population to 207 . In the first mailing there were 35 responses $(16.91 \%)$. After a period of 14 days a follow-up e-mail was sent out to remind the potential respondents to the previous e-mail and if they had not filled out the survey to please do so right away. The second emailing $18(8.70 \%)$ more alumni responded to the survey request, bringing the total to $53(25.60 \%)$. After another period of two weeks a third email call was sent out to those who have not responded to the first two inquiries with a follow-up cover letter and survey. An additional 15 (7.25\%) filled out the survey, bringing the total to $68(32.85 \%)$. Six weeks after the initial survey requests were sent out a last invitation for the alumni to be part of this study was made and two (1\%) more surveys came in. This brought the final number of surveys for the study to 70 for a response rate of $33.82 \%$. The sample size exceeded the $10 \%$ threshold needed to obtain valid path analysis results. 


\section{Data Cleaning}

One of the most time consuming tasks of analyzing the data is data cleaning or data scrubbing. Up to half of data analysis time can be devoted to this work (Tulane University, 2015). The on-line surveys developed for this study was designed using Survey Monkey ${ }^{\circledR}$. One of the tools that are available to the researcher in Survey Monkey ${ }^{\circledR}$ is "Individual Responses" (Survey Monkey, 2015). This tool gives the researcher the ability to examine each individual survey.

As the surveys were returned to me I looked at each individual survey for their completeness. This included looking at every question and their responses to see if any question(s) were not answered, or response(s) that may not have been filled in correctly, or were incomplete. If a question was not answered or a response to a multiple-choice question was not completed the survey could still be used, but those areas that were not answered were not part of the statistical analysis. If a respondent did not complete enough of the survey to be meaningful the survey was discarded, but was noted in the Data Collection section as discarded.

Several of the survey questions had multiple-choice questions that included an "other, please specify" option that needed a written response. Attention was afforded to these responses so that they would be included in the subsequent analysis of the data. Without cleaning answers for this type of item, the "other" response would be over reported and the correct, more specific response would be under reported.

Ideally there is no alternative to having a complete data set, but in almost any research study there will be missing values. In one form or another missing values need to be accounted for or recognized so that in the future any reader of the document can 
have a more accurate interpretation of the work being discussed. I will account for missing values by noting the sections of the instrument they were from. I have chosen to not to replace the missing value(s) with any form of data substitution because it may skew the overall data set and therefore affect the statistical analysis, results and final interpretation of those results (Osborne, 2013). If any values would have made a difference in the study's findings I noted how those missing values were handled for that specific analysis.

\section{Data Analysis}

All data were entered into SPSS ${ }^{\circledR}$ for statistical analysis. Table 3 provides a summary of each research question and its related hypothesis, if any, and how they were analyzed. Some questions were answered with simple descriptive statistical analysis while others required inferential tests. For hypothesis ANOVA, MANOVA and path analysis were computed depending upon variable type.

There were two open-end short answer questions that dealt with courses, concepts or principles the alumni thought should be included in the curriculum or they thought were the more important when they were in the program. Each of the questions had space for only three short answers.

There were five open-ended research questions in each of the surveys that requested a written response. The answers to these questions were subjected to two rounds of coding: initial and axial. The coded data were then organized and presented according to major themes and subthemes. 
Table 3

Research Questions, Hypotheses, Variables, and Statistical Tests

\begin{tabular}{|c|c|c|c|c|}
\hline Research Question & Null Hypothesis & $\begin{array}{l}\text { Independent } \\
\text { Variables }\end{array}$ & Dependent Variables & Statistical Test(s) \\
\hline $\begin{array}{l}\text { Research Question } 1 \\
\text { Do differences exist by } \\
\text { gender and present age in } \\
\text { MIDA alumni perceptions of } \\
\text { experiencing individual } \\
\text { capacity building, course } \\
\text { delivery, project cycle } \\
\text { management, andragogy, } \\
\text { transformative learning, and } \\
\text { transference of learning? }\end{array}$ & $\begin{array}{l}\text { Null Hypothesis } \mathrm{H}_{0} 1 \text { : There } \\
\text { are no statistically significant } \\
\text { differences by gender and } \\
\text { present age in MIDA alumni } \\
\text { perceptions of experiencing } \\
\text { individual capacity building, } \\
\text { course delivery, project cycle } \\
\text { management, andragogy, } \\
\text { transformative learning, and } \\
\text { transference of learning. }\end{array}$ & $\begin{array}{l}\text { Nominal: } \\
\text { Gender - } \\
\text { Alumni } \\
\text { Continuous: } \\
\text { Present Age - } \\
\text { Alumni }\end{array}$ & $\begin{array}{l}\text { Individual Capacity } \\
\text { Building, } \\
\text { Course Delivery, } \\
\text { Project Cycle } \\
\text { Management, } \\
\text { Andragogy, } \\
\text { Transformative } \\
\text { Learning, } \\
\text { Transference of } \\
\text { Learning. }\end{array}$ & MANOVA \\
\hline $\begin{array}{l}\text { Research Question 2. What } \\
\text { are the MIDA alumni } \\
\text { perceptions of experiencing } \\
\text { individual capacity building } \\
\text { while in the program? }\end{array}$ & & & $\begin{array}{l}\text { Alumni perceptions of } \\
\text { development of } \\
\text { individual capacity } \\
\text { building. }\end{array}$ & $\begin{array}{c}\text { Descriptive } \\
\text { Statistics }\end{array}$ \\
\hline $\begin{array}{l}\text { Research Question 3. What } \\
\text { are MIDA alumni perceptions } \\
\text { of the effectiveness of the } \\
\text { teaching, learning and course } \\
\text { delivery processes used for } \\
\text { this program? }\end{array}$ & & & $\begin{array}{l}\text { MIDA Alumni } \\
\text { perceptions of } \\
\text { effectiveness of } \\
\text { course delivery. }\end{array}$ & $\begin{array}{c}\text { Descriptive } \\
\text { Statistics }\end{array}$ \\
\hline
\end{tabular}


Table 3-Continued.

\begin{tabular}{|c|c|c|c|c|}
\hline Research Question & Null Hypothesis & Independent Variables & Dependent Variables & Statistical Test(s) \\
\hline $\begin{array}{l}\text { Research Question } 4 . \\
\text { What are MIDA alumni } \\
\text { perceptions of using } \\
\text { project cycle } \\
\text { management to organize } \\
\text { the program curriculum? }\end{array}$ & & & $\begin{array}{l}\text { MIDA alumni } \\
\text { perceptions of using } \\
\text { project cycle } \\
\text { management to } \\
\text { organize the MIDA } \\
\text { curriculum. }\end{array}$ & $\begin{array}{c}\text { Descriptive } \\
\text { Statistics }\end{array}$ \\
\hline $\begin{array}{l}\text { Research Question 5: } \\
\text { What are MIDA alumni } \\
\text { perceptions of the use of } \\
\text { andragogy in the } \\
\text { program? }\end{array}$ & & & $\begin{array}{l}\text { MIDA alumni } \\
\text { perception of } \\
\text { andragogy. }\end{array}$ & $\begin{array}{c}\text { Descriptive } \\
\text { Statistics }\end{array}$ \\
\hline $\begin{array}{l}\text { Research Question } 6 . \\
\text { What are MIDA alumni } \\
\text { perceptions of the } \\
\text { inclusion of } \\
\text { transformative learning } \\
\text { in the program? }\end{array}$ & & & $\begin{array}{l}\text { MIDA alumni } \\
\text { perceptions of } \\
\text { transformative } \\
\text { learning. }\end{array}$ & $\begin{array}{c}\text { Descriptive } \\
\text { Statistics }\end{array}$ \\
\hline $\begin{array}{l}\text { Research Question } 7 . \\
\text { What are MIDA alumni } \\
\text { perceptions of their } \\
\text { transference of learning } \\
\text { to the overall mission and } \\
\text { work of their employing } \\
\text { agency? }\end{array}$ & & & $\begin{array}{l}\text { MIDA alumni } \\
\text { perceptions of } \\
\text { transference of } \\
\text { learning on the } \\
\text { mission and work of } \\
\text { their employing } \\
\text { agency. }\end{array}$ & $\begin{array}{c}\text { Descriptive } \\
\text { Statistics }\end{array}$ \\
\hline
\end{tabular}


Table 3-Continued.

\begin{tabular}{|c|c|c|c|c|}
\hline Research Question & Null Hypothesis & Independent Variables & Dependent Variables & Statistical Test(s) \\
\hline $\begin{array}{l}\text { Research Question } 8 . \\
\text { Are project cycle } \\
\text { management, } \\
\text { transformative learning, } \\
\text { andragogy, course } \\
\text { delivery, significant } \\
\text { predictors of } \\
\text { transference of learning } \\
\text { mediated by } \\
\text { experiencing individual } \\
\text { capacity building to their } \\
\text { organization? }\end{array}$ & $\begin{array}{l}\mathrm{H}_{0} 2 \text { : Project cycle } \\
\text { management, transformative } \\
\text { learning, andragogy, course } \\
\text { delivery, are not significant } \\
\text { predictors of transference of } \\
\text { learning mediated by } \\
\text { experiencing individual } \\
\text { capacity building to their } \\
\text { organization. }\end{array}$ & $\begin{array}{l}\text { Nominal: Gender - } \\
\text { Alumni } \\
\text { Continuous: Present } \\
\text { Age - Alumni }\end{array}$ & $\begin{array}{l}\text { Individual Capacity } \\
\text { Building, } \\
\text { Course Delivery, } \\
\text { Project Cycle } \\
\text { Management, } \\
\text { Andragogy, } \\
\text { Learning Theory, } \\
\text { Transference of } \\
\text { Learning. }\end{array}$ & Path analysis \\
\hline
\end{tabular}


Table 3-Continued.

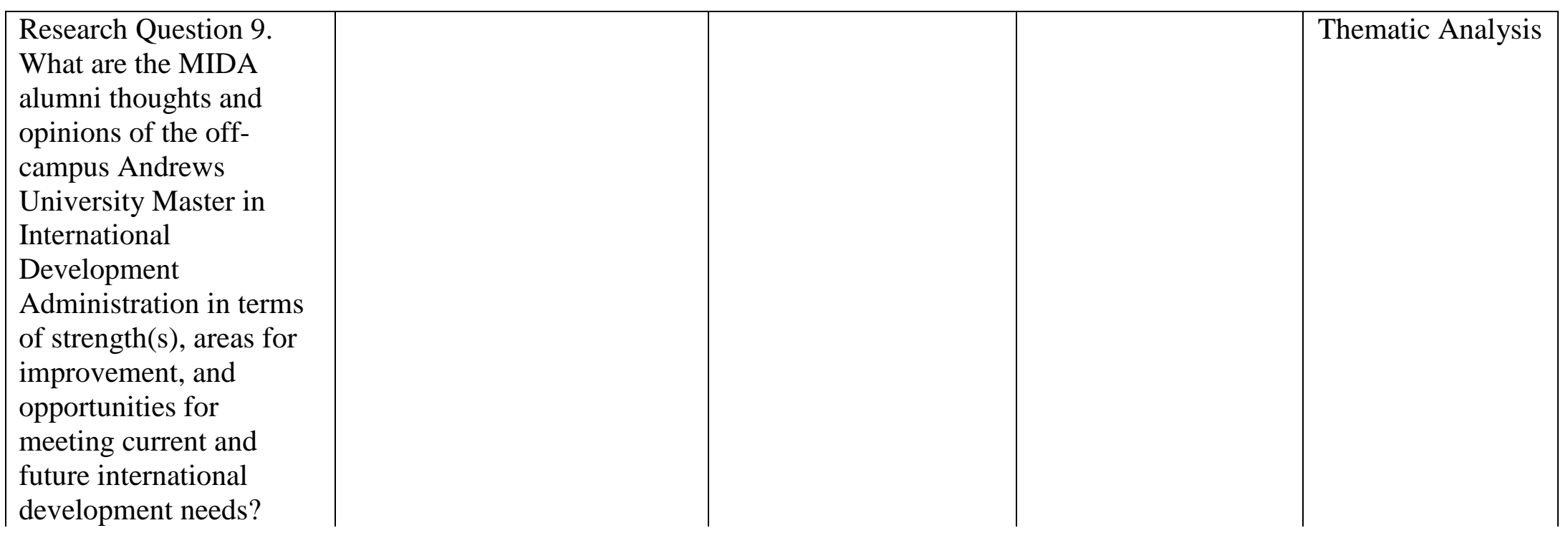


Table 3-Continued.

\begin{tabular}{|l|l|l|l|l|}
\hline Research Question & Null Hypothesis & Independent Variables & Dependent Variables & Statistical Test(s) \\
\hline $\begin{array}{l}\text { Research Question 10. } \\
\text { What are the MIDA } \\
\text { alumni thoughts and } \\
\text { opinions of the off- } \\
\text { campus Andrews }\end{array}$ & & & Thematic Analysis \\
$\begin{array}{l}\text { University Master in } \\
\text { International }\end{array}$ & & & \\
$\begin{array}{l}\text { Development } \\
\text { Administration of } \\
\text { important courses or } \\
\text { concepts that need to be } \\
\text { included or important } \\
\text { concepts or principles } \\
\text { they learned from the }\end{array}$ & & & & \\
program. & & & \\
\hline
\end{tabular}




\section{Statistical Analysis}

In statistical analysis there are two main classes within the field of statistics that are applied to quantitative social science research: descriptive and inferential. Each of these classes of statistics is important in their own right, but accomplishes different objectives (Laerd Statistics, 2015, About Education, 2015). These statistical methods are tools that aid the researcher to organize, interpret, and analyze quantitative data for measuring traits or variables of a population/sample that is being studied (McMillan \& Schumacher, 2005)

Descriptive statistics organizes, and describes the data set in a meaningful way. It is the "most fundamental" and "indispensable" (McMillan \& Schumacher, 2001, p. 207) way to summarize and explain quantitative data. This is done by two different statistical processes. First is by measuring the central tendency of the collected data: the mean, mode, median. The second way is to summarize how dispersed the data set is through measures of spread: range, variance, and standard deviation. Both types of descriptive information can be put into tables, graphs, and charts with accompanying comments to highlight features of the sample (About Education, 2015; Laerd Statistics, 2015; McMillan \& Schumacher, 2001).

Inferential statistics can be used to make predictions, conclusions and generalizations about a population from a randomly chosen sample. This is done through hypothesis testing. In preparation for hypothesis testing, statements are generated about anticipated relationships between groups or variables being studied. These conjectured relationships, called research hypotheses, are typically based on findings from previous studies discovered during the literature review process (McMillan \& Schumacher, 2001). 
Inter-item reliability of the specific elements or scales using Cronbach's alpha was .963 for the project cycle management scale, .908 for the andragogy scale, .865 for the transformative learning scale, .849 for the course delivery scale, .938 for the experiencing individual capacity building scale, and .924 for the transference of learning scale. When all the scales are combined the overall reliability is .827 . The reliability of the component parts of the scales are good to very good, and the overall combined scales is good.

\section{Hypothesis Testing}

Hypothesis testing is conducted on the basis of the null hypotheses rather than the research hypotheses. While a research hypothesis presents a proposed relationship between groups or variables, a null hypothesis $\left(\mathrm{H}_{\mathrm{o}}\right)$ unequivocally says that there is no difference or relationship between the groups or variables being studied (McMillan \& Schumacher, 2001). Testing is based on inductive reasoning theory. "We can never prove" (Thorndike \& Dinnel, 2001, p. 283) a hypothesis to be true, but it can be shown to be false (Howell, 2002). To be able to confirm that a null hypothesis is untrue the researcher applies inferential statistical testing. This determines the probability that the null hypothesis is false (McMillan \& Schumacher, 2001).

\section{Protection of Human Subjects}

The first step I took to ensure proper protection of human subjects in this study was to successfully complete the online training course "Protecting Human Research Participants" from the National Institute of Health (NIH) Office of Extramural Research in July of 2014. Then an application to conduct research using human subject was sent to 
the Office of Research and Creative Scholarship and its Institutional Review Board (IRB) for Andrews University. This application included the purpose of the research study, the methodology, timeframe for the study, and a statement asserting the lack of risk or harm to the participants. This study was categorized as "exempt from full review" by the Andrews University IRB and approved for conducting the study on July 7, 2014 (Appendix C, Letter from IRB to conduct research).

\section{Delimitations of Research}

Even though the course curriculum has been delivered in four different languages (English, French, Russian, and Spanish) and there have been graduates from each of the languages represented, the questionnaires were sent only to those alumni who were in the English sections. This is because the primary investigator's language is English and it would be cost prohibitive to translate the questionnaire into the other languages, and to translate the responses back into English. The conclusions and/or generalizations from the data collected can only be directly applicable to the English-speaking graduates of the MIDA program. However, because the same curriculum was used across all language groups and the graduation requirements are the same, some of the findings from the English section will likely be applicable to program delivery and outcomes in the other languages. 


\section{CHAPTER 4}

\section{RESULTS}

The broad purpose of this dissertation is to investigate perceptions of the quality of the off-campus Master in International Development Administration program of Andrews University, its capacity building effect(s) upon its alumni and the alumni's perceptions of transference of learning upon the organizations that employ them. With this broad purpose there are three sub-objectives: (a) to ascertain if alumni believe they have developed capacity to function more effectively and efficiently because of their participation in the MIDA program, (b) to evaluate from the alumni's perspectives the academic strengths and challenges of the MIDA curriculum as it pertains to capacity building in the arena of international development, and (c) to parse out what lessons can be learned from this off-campus program and how Andrews University can apply these lessons to other off-campus graduate programs.

Survey instruments (Appendix B), that the researcher developed, were sent to the MIDA alumni on their thoughts and perceptions of the off-campus Master of International Development of Andrews University. Data from 70 alumni were analyzed using the software SPSS ${ }^{\circledR}$.

Descriptive statistics, MANOVA, were conducted on the two independent variables, gender and present age, and six dependent variables. Dependent variables included the following: (a) alumni perceptions of development of experiencing individual capacity building, (b) alumni perceptions of effectiveness of course delivery, (c) alumni 
perceptions of using project cycle management to organize the MIDA curriculum, (d) alumni perception of andragogy, (e) alumni perceptions of transformative learning, (f) alumni perceptions of transference of learning on the mission and work of their employing agency. The surveys also contained five open-ended questions. The first asked the alumni to share their thoughts and opinions of the off-campus MIDA program in terms of its strengths. The second question asked about areas of potential improvement. The third question asked respondents to talk about opportunities for meeting current and future international development needs. The fourth question asked the alumni to list three concepts or principles that should be included in the MIDA curriculum. The final question asked for their thoughts on what were the three most important classes or concepts they learned from the program. Responses to these were analyzed thematically. I analyzed the five responses from the alumni to determine what they considered areas of strength(s), areas for improvement, and opportunities for meeting current and future international development needs.

When analyzing data and their interpretation, "One must be cautious lest imagination dives in where evidence fears to tread" (Walton, 1994, p. 87). With these words in mind I present the following findings of this research trying to stay true to the facts they represent.

\section{Demographic Analysis}

A demographic statistical analysis of the MIDA alumni was carried out from data that was collected from the surveys. This type of analysis provides quantifiable characteristics of the sample. Both researcher and reader can then see quickly the types of 
persons who completed the surveys, and their relationship to the research questions being asked.

The first two questions dealt with gender and present age of the persons who were answering the survey at the time it was taken. From the 70 responses there were 38 (54.3\%) females and $32(45.7 \%)$ males. The mean age of the MIDA alumni was 45.46 years, with a median of 44 , a mode of 39 (10\% of the population), with a standard deviation of 9.75 . The sample represented a range of 40 years between the youngest and the oldest respondents, where the minimum age was 25 and the maximum was 65 . On the average the female alumni are younger with a mean of 43.37 years of age, while the male alumni have a mean of 47.94 years, a difference of 4.57 years.

Another age related question was, "How old were you when you graduated from the MIDA?" This tells how old the alumni were when they were finishing their classes. Sixty-nine alumni answered this question: 38 (55.07\%) females and 31 (44.93\%) males. The students had a mean age of 39.42 years with a median of 40.00 and a mode of 41.00 with a standard deviation of 8.42. The ranges in ages were from 24 to 63 with a range of 39 years. The female alumni at the time of graduation were younger with a mean age of 38.05 while the males had a mean age of 41.10 , a difference of 3.05 years.

Subtracting the age at graduation from the present age shows that the persons answering the survey were on the average 6.04 years past graduation. The females are on the average 5.32 years from graduation and the males are on the average 6.54 years from graduation. These data indicate that the alumni respondents have continued in their professional careers more than a few years survey after graduation. Thus, these respondents have had more time to reflect on how the MIDA program has impacted their 
personal and professional lives than more recent graduates.

As stated in the Introduction chapter the students who were accepted into the international development program have a wide range of undergraduate degrees. When asked in the survey, "What was your undergraduate (bachelor degree/first degree) major?" The response included: theology, agriculture, nursing, accounting, chemistry, biology, religion, and psychology. For a complete listing see Appendix E

To ascertain if the alumni had pursued post-graduate degrees or professional training the following question was asked: "Other than the MIDA, do you have any other academic or professional degrees beyond the bachelor's level?" Of the 70 responses 19 (27.10\%) had other academic or professional degrees. Of these 19, 12 (63.16\%) were males and 7 (36.84\%) were females. Their advanced degrees included public health nursing, geography, professional counseling, social work, environmental studies, master in business administration, and doctor of medicine. For a complete listing see Appendix E.

The actual time spent in completing the course work once a student began the program was 3.40 years. The females did the course work on the average in 3.24 years while the males took 3.59 years. Some of the students took as long as 8.00 years to complete the course work.

The MIDA program was advertised as taking five year to complete. On the average the alumni took 5.27 years to complete all the requirements for graduation. The median was 5.00 years with a mode of 4.00 years. One student took as long as 10 years to complete the program. The female alumni averaged 5.26 years while the male alumni averaged 5.28 years. 
There were two questions that dealt with the same subject but at different times in the professional career of the alumni: the type of organizations the alumni worked for at the beginning of the MIDA program versus the types of organization they work for at the time they answered the survey. Table 4 lists the type of organizations, the number and percentages of alumni employed by the different organizations at the beginning of the program and at the time of the survey. The data indicate a marked difference in the original employer and the current employer type. From this information there appears to be a strong tendency for the alumni to move from Faith-based organizations after they graduate from the program. The Faith-based numbers have been cut almost in half, the Government organizations and Private NGOs have doubled their numbers, and the Other category has seen a five-fold increase.

\section{Table 4}

Type of Organization the Alumni are Employed by: Beginning of Program and Now $(N=70)$

\begin{tabular}{|c|c|c|c|c|}
\hline \multirow[t]{2}{*}{ Type of Organization } & \multicolumn{2}{|c|}{ Beginning } & \multicolumn{2}{|c|}{ Now } \\
\hline & Number & Percentage & Number & Percentage \\
\hline Faith-based & 54 & 77.1 & 23 & 32.9 \\
\hline Government organization & 5 & 7.1 & 10 & 14.3 \\
\hline Private NGO & 6 & 8.7 & 11 & 15.7 \\
\hline Other & 5 & 7.1 & 26 & 37.1 \\
\hline Total & 70 & 100.0 & 70 & 100.0 \\
\hline
\end{tabular}

In the Other category at the beginning of the program the kind of work or organization included: ministry, educational institution or student. In the Other now 
category the type of work or organizations the alumni are involved in are more diverse. They include: educational institutions, foundations, private business, self-employed, ministry, PhD student, and unemployed.

A McNemar $\chi^{2}$ crosstab analysis was done to see if there were any correlations between gender and the type of organizations they were employed by at the beginning of the MIDA program, and the types of organization they worked when they answered the survey. As can be seen in Table 5 there is an across-the-board shift in both genders in the type of organizations the alumni worked for at the beginning of the program versus the type of organizations they work for now. Just as the previous table demonstrated, the McNemar $\chi^{2}$ crosstab analysis shows the shift after graduation from the program is away from Faith-based organizations to another type of organization.

\section{Table 5}

Type of Organization the Alumni are Employed by: Beginning of Program and Now According to Gender $(N=70)$

\begin{tabular}{|c|c|c|c|c|}
\hline \multirow{2}{*}{ Type of Organization } & \multicolumn{2}{|c|}{ Beginning } & \multicolumn{2}{|c|}{ Now } \\
\hline & $\mathrm{F}$ & M & $\mathrm{F}$ & M \\
\hline Faith-based & $30(78.9 \%)$ & $24(75.0 \%)$ & $12(31.6 \%)$ & $11(34.4 \%)$ \\
\hline Government organization & $2(5.3 \%)$ & $3(9.4 \%)$ & $3(7.9 \%)$ & $7(21.9 \%)$ \\
\hline Private NGO & $2(5.3 \%)$ & $4(12.5 \%)$ & $5(13.2 \%)$ & $6(18.8 \%)$ \\
\hline Other & $4(10.5 \%)$ & $1(3.1 \%)$ & $18(47.4 \%)$ & $8(25.0 \%)$ \\
\hline Totals & $38(100 \%)$ & $32(100 \%)$ & $38(100 \%)$ & $32(100 \%)$ \\
\hline
\end{tabular}

Note. $\mathrm{F}=$ females; $\mathrm{M}=$ males. 
With a graduate degree in international development there is the possibility of career advancement for the MIDA alumni. The question was asked "How do your present responsibilities and/or job title compare with your job when you entered the MIDA?" Table 6 shows the results of this question. Overall $71.00 \%$ of the MIDA had a higher level of responsibilities/job titles because of the international development program. While $27.50 \%$ thought their present responsibilities/job title were at a lower level than when they began the program.

Table 6

Present Responsibilities Compared With Before the MIDA Program by Gender (69)

\begin{tabular}{|c|c|c|c|c|}
\hline & & $\mathrm{F}$ & $\mathrm{M}$ & Total \\
\hline Now at a higher level & & $27(71.10 \%)$ & $22(71.00 \%)$ & $49(71.00 \%)$ \\
\hline Still about the same & & $1(2.60 \%)$ & $0 \quad(0.00 \%)$ & $1(1.40 \%)$ \\
\hline \multirow[t]{2}{*}{ Now at a lower level } & & $10(26.30 \%)$ & $9(29.00 \%)$ & $19(27.50 \%)$ \\
\hline & Total & $38(100 \%)$ & $31(100 \%)$ & $69(100 \%)$ \\
\hline
\end{tabular}

Note. $\mathrm{F}=$ females; $\mathrm{M}=$ males.

When the alumni were asked if their organization used project cycle management to design and manage development projects 53 (75.7\%) answered "yes," and $17(24.3 \%)$ answered "other."

In the MIDA alumni survey one question that dealt with the application process and another concerned communication with the international development office during the application process. Fifty-three $(75.70 \%)$ of the applicants found no problem with the application process, while $12(17.10 \%)$ had some minor problem, and five $(7.20 \%)$ found 
the process complicated or had at least one major problem. In the area of communication $51(72.80 \%)$ thought there was very good to excellent communication between themselves and the international development office, $14(20.00 \%)$ rated it as good, and five $(7.10 \%)$ thought it was fair.

Another question asked the alumni if they would recommend the MIDA program to someone else. Out of the 69 responses 45 (65.20\%) would highly recommend the program, another $20(29.00 \%)$ would likely recommend, when combined, these percentages show that over $94 \%$ of the alumni would recommend the program while 4 $(5.80 \%)$ would be neutral in the recommendation. There were no unlikely or not recommend responses.

There were several ways that the MIDA alumni learned about the graduate program in international development offered by Andrews University. Out of the 61 who answered this question $24(39.34 \%)$ learned about it from colleagues that had attended or graduated from the program. The supervisor was the information source for $22(36.06 \%)$ others. A few, 5 (8.20\%), obtained their information from the internet. Ten $(16.40 \%)$ learned from a variety of sources such as, relatives, advertisement posters, announcements about the program while attending an ADRA conference, or were part of the original group that worked for ADRA when the program began in 1995 .

\section{Responses to the Research Questions}

Originally there were 21 research questions in this study that dealt with the perceptions of the MIDA alumni and their employing agency about the off-campus program in international development of Andrews University. Because of the low 
sample size (5) from the organizational survey, these research questions and accompanying null hypotheses were not included into the study.

The item statements in the survey aligned with each of the research questions. The following scale designation was used: 1 = Strongly disagree; $2=$ Disagree; $3=$ Neither agree nor disagree; $4=$ Agree; and $5=$ Strongly agree. Because responses toward the program were strongly positive, my discussion focusses primarily on the percentages of respondents who strongly agreed or agreed with each other. There are a few items where this response pattern did not hold true. In those cases, I point out the negative response pattern.

\section{Research Question 1 and Null Hypothesis $\mathrm{H}_{0} 1$}

Do differences exist by gender and present age in MIDA alumni perceptions of experiencing individual capacity building, course delivery, project cycle management, andragogy, transformative learning, and transference of learning? Null Hypothesis $\mathrm{H}_{0} 1$ : There are no statistically significant differences by gender and present age in MIDA alumni perceptions of experiencing individual capacity building, course delivery, project cycle management, andragogy, transference of learning, and transference of learning.

A two-way MANOVA was performed on the data from the MIDA alumni perceptions of the off-campus program in international development offered by Andrews University. Six dependent variables were included in this analysis. These variables are: Experiencing Individual Capacity Building, Course Delivery, Project Cycle Management, Andragogy, Transformative Learning, and Transference of Learning. Each of these variables was measured by a scale on the survey instrument. Two independent variable 
were used in the MANOVA: gender and present age. Type III sums of squares were used to adjust for any minor confounding between factors that occurred because of the slightly unequal $n s$ in the cells. The SS expression for each effect in this design was calculated controlling for all effects.

Preliminary data screening did not indicate any serious violations of the assumptions for MANOVA with the exception of multicollinearity. Correlations among the dependent variables ranged from .61 to .88 (see Table 7). While these values were large enough to raise concerns about multicollinearity, the MANOVA was conducted using Wilks' $\Lambda$ as a follow up test.

Table 7

Results of Simultaneous Multiple Regression to Predict of Alumni Impact on Transference of Learning (Y) From PCM, TrLn, Andr, CoDl, CaBd

\begin{tabular}{ccccccc}
\hline & TL & PCM & TrLn & Andr & CoDl & CaBd \\
\hline PCM & $.69^{* * * *}$ & & & & & \\
TrLn & $.63^{* * *}$ & $.61^{* * * *}$ & & & & \\
Andr & $.74^{* * *}$ & $.69^{* * * *}$ & $.80^{* * * *}$ & & & \\
CoDl & $.70^{* * * *}$ & $.72^{* * *}$ & $.70^{* * *}$ & $.77^{* * *}$ & & \\
CaBd & $.88^{* * *}$ & $.73^{* * *}$ & $.67^{* * *}$ & $.75^{* * *}$ & $.66^{* * *}$ & \\
& & & & & & \\
Mean & 39.19 & 51.85 & 39.94 & 42.26 & 76.18 & 30.26 \\
SD & 5.56 & 6.76 & 5.63 & 5.81 & 8.74 & 4.62 \\
\hline
\end{tabular}

Note. TL $=$ Transference of learning, $\mathrm{PCM}=$ project cycle management;

$\operatorname{TrLn}=$ transformative learning; Andr = andragogy; $\mathrm{CoDl}=$ course delivery; $\mathrm{CaBd}=$ experiencing individual capacity building.

${ }^{*} p<.05,{ }^{* *} p<.01,{ }^{* * *} p<.001$

Overall the MANOVA indicated there were no significant interaction effects between gender and present age $F(30,206)=1.170, p=.259$; Wilks's $\Lambda=.533$. Tests of Between-Subject effects revealed no significant differences, based on gender, in MIDA 
alumni perceptions of experiencing individual capacity building, course delivery, project cycle management, andragogy, transformative learning, and transference of learning (see Table 8).

Table 8

Analysis of Simple Main Effects for Gender

\begin{tabular}{|l|c|c|}
\hline \multicolumn{1}{|c|}{ Scale } & Univariate $F$ & Univariate $p$ \\
\hline Individual Capacity Building & .348 & .558 \\
\hline Course Delivery & .090 & .765 \\
\hline Project Cycle Management, & .238 & .628 \\
\hline Andragogy & .055 & .815 \\
\hline Learning Theory & .367 & .547 \\
\hline Transference of Learning & .008 & .931 \\
\hline
\end{tabular}

Tests of Between-Subject effects revealed no significant differences, based on present age, in MIDA alumni perceptions of experiencing individual capacity building, course delivery, project cycle management, andragogy, transformative learning, and transference of learning (see Table 9).

Table 9

Analysis of Simple Main Effects for Present Age

\begin{tabular}{|l|c|c|}
\hline \multicolumn{1}{|c|}{ Scale } & Univariate $F$ & Univariate $p$ \\
\hline Individual Capacity Building & .899 & .488 \\
\hline Course Delivery & 1.548 & .190 \\
\hline Project Cycle Management & 1.909 & .107 \\
\hline Andragogy & 1.753 & .138 \\
\hline Learning Theory & 1.582 & .180 \\
\hline Transference of Learning & .970 & .444 \\
\hline
\end{tabular}


Therefore, the null hypothesis $\mathrm{H}_{0} 1$ is retained that there are no significant differences by gender and present age in MIDA alumni perceptions of experiencing individual capacity building, course delivery, project cycle management, andragogy, transformative learning, and transference of learning.

\section{Research Question 2}

What are the MIDA alumni perceptions of experiencing individual capacity building while in the program?

Seven items in the survey evaluated the individual capacity building of the international development program (see Table 10). Combining the strongly agree and agree response percentages the alumni gave the international development program an 85-92\% rating for building their capacity as individuals. Thus it appears that the program from the alumni perspective achieved its goal of developing capacity in international development professionals it served.

Table 10

Individual Capacity Building and the MIDA Alumni

\begin{tabular}{|c|c|c|c|c|c|}
\hline & SA & A & $\mathrm{N}$ & $\mathrm{D}$ & SD \\
\hline The MIDA Program ... & $\begin{array}{c}\mathrm{n} \\
(\%)\end{array}$ & $\begin{array}{l}\mathrm{n} \\
(\%)\end{array}$ & $\begin{array}{c}\mathrm{n} \\
(\%)\end{array}$ & $\begin{array}{c}\mathrm{n} \\
(\%)\end{array}$ & $\begin{array}{c}\mathrm{n} \\
(\%)\end{array}$ \\
\hline $\begin{array}{l}\text { instilled in me capacity building } \\
\text { principles and concepts. }(\mathrm{N}=69)\end{array}$ & $\begin{array}{r}30 \\
(43.5)\end{array}$ & $\begin{array}{r}33 \\
(43.5)\end{array}$ & $\begin{array}{r}5 \\
(7.2)\end{array}$ & $\begin{array}{r}1 \\
(1.4)\end{array}$ & $\begin{array}{r}0 \\
(0.0)\end{array}$ \\
\hline $\begin{array}{l}\text { helped me develop individual } \\
\text { capacity building to function as } \\
\text { an international development } \\
\text { professional. }(\mathrm{N}=69)\end{array}$ & $\begin{array}{r}35 \\
(50.7)\end{array}$ & $\begin{array}{r}29 \\
(42.0)\end{array}$ & $\begin{array}{r}3 \\
(4.3)\end{array}$ & $\begin{array}{r}2 \\
(2.9)\end{array}$ & $\begin{array}{r}0 \\
(0.0)\end{array}$ \\
\hline
\end{tabular}


Table 10-Continued

\begin{tabular}{|c|c|c|c|c|c|}
\hline $\begin{array}{l}\text { helped me contribute to the } \\
\text { capacity building efficacy of my } \\
\text { employing organization. ( } \mathrm{N}=68)\end{array}$ & $\begin{array}{r}34 \\
(50.0)\end{array}$ & $\begin{array}{r}25 \\
(36.8)\end{array}$ & $\begin{array}{r}7 \\
(10.3)\end{array}$ & $\begin{array}{r}2 \\
(2.9)\end{array}$ & $\begin{array}{c}0 \\
(0.0)\end{array}$ \\
\hline $\begin{array}{l}\text { prepared me to enhance the } \\
\text { quality development in society. } \\
(\mathrm{N}=69)\end{array}$ & $\begin{array}{r}32 \\
(46.4)\end{array}$ & $\begin{array}{r}28 \\
(40.4)\end{array}$ & $\begin{array}{r}7 \\
(10.1)\end{array}$ & $\begin{array}{r}2 \\
(2.9)\end{array}$ & $\begin{array}{c}0 \\
(0.0)\end{array}$ \\
\hline $\begin{array}{l}\text { prepared me to enhance the } \\
\text { dignity of human development in } \\
\text { society. }(\mathrm{N}=69)\end{array}$ & $\begin{array}{r}35 \\
(50.7)\end{array}$ & $\begin{array}{r}26 \\
(37.7)\end{array}$ & $\begin{array}{r}6 \\
(8.7)\end{array}$ & $\begin{array}{r}2 \\
(2.9)\end{array}$ & $\begin{array}{c}0 \\
(0.0)\end{array}$ \\
\hline $\begin{array}{l}\text { prepared me to meet the } \\
\text { changing needs within the } \\
\text { international development } \\
\text { community. }(\mathrm{N}=69)\end{array}$ & $\begin{array}{c}32 \\
(46.4)\end{array}$ & $\begin{array}{r}30 \\
(43.5)\end{array}$ & $\begin{array}{c}5 \\
(7.2)\end{array}$ & $\begin{array}{r}2 \\
(2.9)\end{array}$ & $\begin{array}{r}0 \\
(0.0)\end{array}$ \\
\hline $\begin{array}{l}\text { helped me to broaden my } \\
\text { professional networking with } \\
\text { other organizations or within my } \\
\text { own organization. }(\mathrm{N}=68)\end{array}$ & $\begin{array}{r}34 \\
(50.0)\end{array}$ & $\begin{array}{r}24 \\
(35.3)\end{array}$ & $\begin{array}{c}6 \\
(8.8)\end{array}$ & $\begin{array}{r}4 \\
(5.9)\end{array}$ & $\begin{array}{r}0 \\
(0.0)\end{array}$ \\
\hline
\end{tabular}

Note. $\mathrm{SA}=$ strongly agree; $\mathrm{A}=$ agree $; \mathrm{N}=$ neither agree nor disagree; $\mathrm{D}=$ disagree;

$\mathrm{SD}=$ strongly disagree $\mathrm{n}=$ number of respondents; $\%=$ percentage of total number.

\section{Research Question 3}

What are MIDA alumni perceptions of the effectiveness of the teaching, learning, and course delivery processes used for this program?

There were 23 different items in this area of teaching, learning, and course delivery that were asked in the alumni survey (see Table 11). When asked what would be the ideal class size for the type of instruction they were receiving. Seventy of the alumni said that 25 students per class would be considered the best class size, with a range of 10 to 42 students per class. When asked what the actual class size average was, 69 alumni responded and said the classes averaged 35 students per class with a range of 8 to 80 
students per class.

Table 11

MIDA Course Delivery and the MIDA Alumni

What would you consider the ideal number of

\begin{tabular}{ccccc}
$\mathrm{SA}$ & $\mathrm{A}$ & $\mathrm{N}$ & $\mathrm{D}$ & $\mathrm{SD}$ \\
\hline $\mathrm{n}$ & $\mathrm{n}$ & $\mathrm{n}$ & $\mathrm{n}$ & $\mathrm{n}$
\end{tabular}

$(\%) \quad(\%) \quad(\%) \quad(\%) \quad(\%)$

students per class in order to provide the best NA NA NA NA NA

learning experience?* $(\mathrm{N}=70)$

What was the average number of students in

most of the classes you took?* $(\mathrm{N}=69)$

NA NA NA NA NA

Course materials, when provided, were useful

in facilitating my learning the course. $(\mathrm{N}=70)$

$\begin{array}{rrrrr}31 & 34 & 4 & 1 & 0 \\ (44.3) & (48.6) & (5.7) & (1.4) & (0.0)\end{array}$

Course instructors referred to or used these course materials while teaching the course.* $(\mathrm{N}=70)$

NA NA NA NA NA

The course materials were of high quality. ( $N$

$=69$ )

$\begin{array}{rrrrr}23 & 33 & 9 & 4 & 0\end{array}$

$\begin{array}{lllll}(32.9) & (47.8) & (13.0) & (5.8) & (0.0)\end{array}$

The course materials were academically

challenging. $(\mathrm{N}=70)$

$\begin{array}{rrrrr}15 & 34 & 10 & 10 & 1 \\ (21.4) & (48.6) & (14.3) & (14.3) & (1.4)\end{array}$

Pre-session assignments, when given, were

$23 \quad 29 \quad 14$

$\begin{array}{rr}3 & 1 \\ (4.3) & (1.4)\end{array}$

useful in helping me understand what the

face-to-face course was going to be about. ( $\mathrm{N}$

(32.9) (41.1) (20.0)

$=70$ )

Post-session assignments or projects, when given, helped me reinforce the principles or concepts of the courses. $(\mathrm{N}=70)$

The courses covered the right amount of topics for the amount of time allotted. $(\mathrm{N}=$ 69)

$\begin{array}{rrrrr}40 & 27 & 3 & 0 & 0 \\ (57.1) & (38.6) & (4.3) & (0.0) & (0.0) \\ & & & & \\ 18 & 42 & 5 & 4 & 0 \\ (26.1) & (60.9) & (7.2) & (5.8) & (0.0)\end{array}$




\section{Table 11-Continued}

The students in the program had equal levels of knowledge in the area of international development coming into the program. $(\mathrm{N}=$ 69)

The students in the program had about equal levels of experience in international development coming into the program. $(\mathrm{N}=$ 70)

I learned from the professional experiences of other students that were in the program. $(\mathrm{N}=$ 69)

The instructors were knowledgeable about what they taught. $(\mathrm{N}=70)$

The instructors fostered in-class discussions between themselves and the students. ( $\mathrm{N}=$ 70)

The instructors fostered in-class discussions between students about the principles and/or concepts being taught during the course. ( $\mathrm{N}$ $=70$ )

The instructors were available for after-class discussions with students to explain or clarify concepts or class requirements. $(\mathrm{N}=70)$

The MIDA program strengthened knowledge from my undergraduate degree. $(\mathrm{N}=70)$

The MIDA program has reinforced my previous on-the-job learning experiences. ( $\mathrm{N}$ $=70)$

My concentration research mentor was instrumental to my success in the research process. $(\mathrm{N}=67)$

My concentration research mentor helped me in my research project. $(\mathrm{N}=69)$ $\begin{array}{rrrrr}31 & 33 & 3 & 2 & 0 \\ (44.9) & (47.8) & (4.3) & (2.9) & (0.0)\end{array}$

$\begin{array}{rrrrr}35 & 31 & 2 & 2 & 0 \\ (50.0) & (44.3) & (2.9) & (2.9) & (0.0) \\ & & & & \\ 31 & 34 & 3 & 2 & 0 \\ (44.3) & (48.6) & (4.3) & (2.9) & (0.0)\end{array}$

$\begin{array}{rrrrr}29 & 36 & 4 & 1 & 0 \\ (41.4) & (51.4) & (5.7) & (1.4) & (0.0)\end{array}$

$\begin{array}{rrrrr}22 & 38 & 7 & 3 & 0 \\ (31.4) & (54.3) & (10.0) & (4.3) & (0.0)\end{array}$

$\begin{array}{rrrrr}29 & 23 & 11 & 6 & 1 \\ (41.4) & (32.9) & (15.7) & (8.6) & (1.4)\end{array}$

$\begin{array}{rrrrr}35 & 28 & 6 & 0 & 1 \\ (50.0) & (40.0) & (8.6) & (0.0) & (1.4)\end{array}$

$\begin{array}{rrrrr}26 & 22 & 14 & 3 & 2 \\ (38.8) & (32.8) & (20.9) & (4.5) & (3.0)\end{array}$

$\begin{array}{rrrrr}26 & 25 & 15 & 2 & 1 \\ (37.7) & (36.2) & (21.7) & (2.9) & (1.4)\end{array}$




\section{Table 11-Continued}

My concentration research mentor pointed me to resources that could be helpful in my

research project. $(\mathrm{N}=69)$

The Andrews University Institutional Board Review (IRB) process for getting permission to do your research was easy to complete. $(\mathrm{N}$ $=68)$

Who was the most helpful to you in completing the IRB process?

Note. $\mathrm{SA}=$ strongly agree $; \mathrm{A}=$ agree $; \mathrm{N}=$ neither agree nor disagree; $\mathrm{D}=$ disagree; $\mathrm{SD}=$ strongly disagree; $\mathrm{n}=$ number of respondents; $\%=$ percentage of total number; $*=$ another scale used; NA = not applicable.

Combining the strongly agree and agree response percentages the alumni gave the international development program an 59-95\% rating in effectiveness of teaching, learning, and course delivery processes used in the program. Overall the alumni were pleased with how the courses were delivered, the effectiveness of the teaching, and the learning experience.

Two questions dealt with the students opinions of their fellow students. About $69 \%$ thought that none of the students had equal knowledge or experience in international development.

One question asked about how often the teachers referred to the printed course materials (textbooks, course modules, and handouts.) The printed course materials were referred to about $70 \%$ of the time.

When it came to the Institutional Review Board (IRB) of Andrews University and the process that students needed to go through to get their research projects approved, the question was asked who was the most helpful in this process. Out of the 70 responses, 
$49 \%$ (34) stated that the concentration research mentor was the most helpful, 27\% (19) gave credit to the program director, almost 9\% (6) said it was part of the research methodology class, and 14\% (10) answered Other, either it was not required when they were in the program or they did not remember doing it.

\section{Research Question 4}

What are MIDA alumni perceptions of using project cycle management to organize the program curriculum?

The alumni gave project cycle management very high marks as a template to organize the MIDA curriculum (see Table 12). The combined percentages of strongly agree and agree on the 12 survey questions about PCM ranged from the low to mid 90's, with one exception of almost 84\% (83.6-95.6\%).

Table 12

Project Cycle Management (PCM) and the MIDA Alumni

\begin{tabular}{|c|c|c|c|c|c|}
\hline & SA & A & $\mathrm{N}$ & $\mathrm{D}$ & SD \\
\hline Using the core courses and PCM together was ... & $\begin{array}{c}\mathrm{n} \\
(\%)\end{array}$ & $\begin{array}{c}\mathrm{n} \\
(\%)\end{array}$ & $\begin{array}{c}\mathrm{n} \\
(\%)\end{array}$ & $\begin{array}{c}\mathrm{n} \\
(\%)\end{array}$ & $\begin{array}{c}\mathrm{n} \\
(\%)\end{array}$ \\
\hline a good academic method to teach about & 32 & 33 & 2 & 0 & 1 \\
\hline international development. $(\mathrm{N}=68)$ & $(47.1)$ & $(48.5)$ & $(2.9)$ & $(0.0)$ & $(1.5)$ \\
\hline a good framework to learn about the & 35 & 31 & 1 & 0 & 1 \\
\hline $\begin{array}{l}\text { interconnected phases of project development. }(\mathrm{N} \\
=68)\end{array}$ & $(50.0)$ & $(45.6)$ & $(1.4)$ & $(0.0)$ & $(1.4)$ \\
\hline $\begin{array}{l}\text { a good model for learning how to write project } \\
\text { proposals. }(\mathrm{N}=68)\end{array}$ & $\begin{array}{r}29 \\
(41.4)\end{array}$ & $\begin{array}{r}34 \\
(50.0)\end{array}$ & $\begin{array}{r}4 \\
(5.9)\end{array}$ & $\begin{array}{r}1 \\
(1.5)\end{array}$ & $\begin{array}{r}0 \\
(0.0)\end{array}$ \\
\hline a good approach to learn team building. $(\mathrm{N}=67)$ & $\begin{array}{r}24 \\
(35.8)\end{array}$ & $\begin{array}{r}32 \\
(47.8)\end{array}$ & $\begin{array}{r}10 \\
(14.3)\end{array}$ & $\begin{array}{r}1 \\
(1.5)\end{array}$ & $\begin{array}{r}0 \\
(0.0)\end{array}$ \\
\hline
\end{tabular}




\section{Table 12-Continued}

\begin{tabular}{|c|c|c|c|c|c|}
\hline $\begin{array}{l}\text { a good approach to learn how to implement } \\
\text { development projects. }(\mathrm{N}=68)\end{array}$ & $\begin{array}{r}35 \\
(51.5)\end{array}$ & $\begin{array}{r}30 \\
(44.1)\end{array}$ & $\begin{array}{r}2 \\
(2.9)\end{array}$ & $\begin{array}{r}1 \\
(1.5)\end{array}$ & $\begin{array}{r}0 \\
(0)\end{array}$ \\
\hline $\begin{array}{l}\text { a good approach for learning how to understand } \\
\text { the financial side of a development project. }(\mathrm{N}= \\
68)\end{array}$ & $\begin{array}{r}25 \\
(36.8)\end{array}$ & $\begin{array}{r}38 \\
(55.9)\end{array}$ & $\begin{array}{r}4 \\
(5.9)\end{array}$ & $\begin{array}{r}1 \\
(1.5)\end{array}$ & $\begin{array}{r}0 \\
(0.0)\end{array}$ \\
\hline $\begin{array}{l}\text { a good approach for learning how to evaluate a } \\
\text { development project. }(\mathrm{N}=67)\end{array}$ & $\begin{array}{r}33 \\
(49.3)\end{array}$ & $\begin{array}{r}29 \\
(43.3)\end{array}$ & $\begin{array}{r}3 \\
(4.5)\end{array}$ & $\begin{array}{r}2 \\
(3.0)\end{array}$ & $\begin{array}{r}0 \\
(0.0)\end{array}$ \\
\hline $\begin{array}{l}\text { PCM is a good model... } \\
\text { which the organization could use in its own } \\
\text { development mission. }(\mathrm{N}=68)\end{array}$ & $\begin{array}{r}- \\
28 \\
(41.2)\end{array}$ & $\begin{array}{r}- \\
37 \\
(54.4)\end{array}$ & $\begin{array}{r}- \\
1 \\
(1.4)\end{array}$ & $\begin{array}{r}- \\
2 \\
(2.9)\end{array}$ & $\begin{array}{r}- \\
0 \\
(0.0)\end{array}$ \\
\hline for individual capacity building. $(\mathrm{N}=67)$ & $\begin{array}{r}24 \\
(35.8)\end{array}$ & $\begin{array}{r}35 \\
(52.2)\end{array}$ & $\begin{array}{r}7 \\
(10.4)\end{array}$ & $\begin{array}{r}1 \\
(1.5)\end{array}$ & $\begin{array}{r}0 \\
(0.0)\end{array}$ \\
\hline for organizational capacity building. $(\mathrm{N}=68)$ & $\begin{array}{r}26 \\
(38.2)\end{array}$ & $\begin{array}{r}38 \\
(55.9)\end{array}$ & $\begin{array}{r}2 \\
(2.9)\end{array}$ & $\begin{array}{r}2 \\
(2.9)\end{array}$ & $\begin{array}{r}0 \\
(0.0)\end{array}$ \\
\hline $\begin{array}{l}\text { to follow for managing development projects. }(\mathrm{N} \\
=68)\end{array}$ & $\begin{array}{r}35 \\
(51.5)\end{array}$ & $\begin{array}{r}30 \\
(44.1)\end{array}$ & $\begin{array}{r}2 \\
(2.9)\end{array}$ & $\begin{array}{r}1 \\
(1.5)\end{array}$ & $\begin{array}{r}0 \\
(0.0)\end{array}$ \\
\hline to do development. $(\mathrm{N}=35)$ & $\begin{array}{r}33 \\
(50.8)\end{array}$ & $\begin{array}{r}28 \\
(43.1)\end{array}$ & $\begin{array}{r}3 \\
(4.6)\end{array}$ & $\begin{array}{r}1 \\
(1.5)\end{array}$ & $\begin{array}{r}0 \\
(0.0)\end{array}$ \\
\hline
\end{tabular}

Note. $\mathrm{SA}=$ strongly agree; $\mathrm{A}=$ agree $\mathrm{N}=$ neither agree nor disagree; $\mathrm{D}=$ disagree; $\mathrm{SD}=$ strongly disagree; $\mathrm{n}=$ number of respondents; $\%=$ percentage of total number.

\section{Research Question 5}

What are MIDA alumni perceptions of the use of andragogy in the program?

The theory of andragogy, adult learning, was an integral part of the approach in teaching and learning within the MIDA program. The ten questions asked in this part of the survey reflect different aspects of the andragogy theory.

When a frequency analysis was conducted for this research question the results are found in Table 13. Even though the alumni may not have been aware that andragogy theory was 
being used in the teaching of their classes they gave it high marks of 78.2-92.8\% on the combined strongly agree and agree opinions.

Table 13

The Use of Andragogy Theory and the MIDA Alumni

During my experience within the MIDA program, ... the professors helped me understand WHY the content of their courses was important. $(\mathrm{N}=$ 69)

the professors allowed me to be more selfdirected as a learner when appropriate. $(\mathrm{N}=$ 69)

the professors allowed me to be more independent as a learner when appropriate. ( $\mathrm{N}$ $=69$ )

the professors expected me to draw from my experiences to advance my learning in their classes. $(\mathrm{N}=69)$

the professors planned activities requiring me to connect previous experiences to new learning in their classes. $(\mathrm{N}=68)$

my classes engaged me because they were related to real-life international development situations. $(\mathrm{N}=69)$

I was able to apply new concepts and ideas about international development immediately. $(\mathrm{N}=69)$

\begin{tabular}{ccccc} 
SA & $\mathrm{A}$ & $\mathrm{N}$ & $\mathrm{D}$ & $\mathrm{SD}$ \\
\hline $\mathrm{n}$ & $\mathrm{n}$ & $\mathrm{n}$ & $\mathrm{n}$ & $\mathrm{n}$ \\
$(\%)$ & $(\%)$ & $(\%)$ & $(\%)$ & $(\%)$ \\
26 & 36 & 6 & 0 & 1 \\
$(37.7)$ & $(52.2)$ & $(8.7)$ & $(0.0)$ & $(1.4)$
\end{tabular}

$\begin{array}{rrrrr}25 & 36 & 7 & 0 & 1 \\ (36.2) & (52.2) & (10.1) & (0.0) & (1.4)\end{array}$

$\begin{array}{rrrrr}27 & 35 & 6 & 0 & 1 \\ (39.1) & (50.7) & (8.7) & (0.0) & (1.4)\end{array}$

$\begin{array}{rrrrr}32 & 30 & 4 & 2 & 1 \\ (46.4) & (43.5) & (5.8) & (2.9) & (1.4)\end{array}$

$\begin{array}{rrrrr}28 & 30 & 7 & 2 & 1 \\ (41.2) & (44.1) & (10.3) & (2.9) & (1.5)\end{array}$

$\begin{array}{rrrrr}28 & 36 & 3 & 1 & 1 \\ (40.6) & (52.2) & (4.3) & (1.4) & (1.4)\end{array}$

$\begin{array}{rrrrr}28 & 35 & 3 & 2 & 1 \\ (40.6) & (50.7) & (4.3) & (2.9) & (1.4)\end{array}$


Table 13-Continued

my classes focused on solving real-life practical problems rather than memorizing international development course content. ( $\mathrm{N}$ =69)

$\begin{array}{rrrrr}28 & 35 & 5 & 0 & 1 \\ (40.6) & (50.7) & (7.2) & (0.0) & (1.4)\end{array}$

my motivation to learn came more from within

myself than from my professors. $(\mathrm{N}=69)$

$\begin{array}{rrrrr}23 & 31 & 14 & 0 & 1 \\ (33.3) & (44.9) & (20.3) & (0.0) & (1.4) \\ & & & & \\ 28 & 30 & 7 & 3 & 0 \\ (41.2) & (44.1) & (10.3) & (4.4) & (0.0)\end{array}$

I enthusiastically continued my professional development in international development. ( $\mathrm{N}$ $=68)$

Note. $\mathrm{SA}=$ strongly agree; $\mathrm{A}=$ agree; $\mathrm{N}=$ neither agree nor disagree; $\mathrm{D}=$ disagree; $\mathrm{SD}=$ strongly disagree $\mathrm{n}=$ number of respondents; $\%=$ percentage of total number.

\section{Research Question 6}

What are MIDA alumni perceptions of the inclusion of transformative learning in the program?

Ten items from the survey dealt with different aspects of transformative learning as outlined in the Literature Review chapter. As Table 14 points out almost all the alumni thought the inclusion of transformative learning theory into the program was a good, with between $66.7-95.6 \%$ of the respondents selecting the strongly agree and agree options, even though they may not have been aware of it being used. There was one exception and that was in the area of how learning effects their emotions. There was almost an even split between the strongly agree and agree at $39.1 \%$, and $42 \%$ for disagree and strongly disagree, with $18.8 \%$ being neutral. This would indicate that the alumni have mixed thoughts about the idea of learning effecting their emotions. 
Table 14

The Use of Transformative Learning and the MIDA Alumni

\begin{tabular}{|c|c|c|c|c|c|}
\hline & SA & $\mathrm{A}$ & $\mathrm{N}$ & $\mathrm{D}$ & $\mathrm{SA}$ \\
\hline & $\begin{array}{l}\mathrm{n} \\
(\%)\end{array}$ & $\begin{array}{c}\mathrm{n} \\
(\%)\end{array}$ & $\begin{array}{c}\mathrm{n} \\
(\%)\end{array}$ & $\begin{array}{l}\mathrm{n} \\
(\%)\end{array}$ & $\begin{array}{c}\mathrm{n} \\
(\%)\end{array}$ \\
\hline $\begin{array}{l}\text { The learning process involved one or more of } \\
\text { the five senses (taste, sight, touch, hearing, and } \\
\text { smell). }(\mathrm{N}=69)\end{array}$ & $\begin{array}{r}22 \\
(31.9)\end{array}$ & $\begin{array}{r}33 \\
(47.8)\end{array}$ & $\begin{array}{r}10 \\
(14.5)\end{array}$ & $\begin{array}{r}4 \\
(5.8)\end{array}$ & $(0.0)$ \\
\hline $\begin{array}{l}\text { Reflection was part of the learning process. ( } N \\
=69)\end{array}$ & $\begin{array}{r}25 \\
(36.2)\end{array}$ & $\begin{array}{r}39 \\
(56.5)\end{array}$ & $\begin{array}{r}5 \\
(7.2)\end{array}$ & $\begin{array}{r}0 \\
(0.0)\end{array}$ & $\begin{array}{r}0 \\
(0.0)\end{array}$ \\
\hline $\begin{array}{l}\text { I was able to take learning moments and } \\
\text { transform and internalize them into a new } \\
\text { "mental meaning." }(\mathrm{N}=68)\end{array}$ & $\begin{array}{r}22 \\
(32.4)\end{array}$ & $\begin{array}{r}37 \\
(54.4)\end{array}$ & $\begin{array}{r}9 \\
(13.2)\end{array}$ & $\begin{array}{r}0 \\
(0.0)\end{array}$ & $\begin{array}{r}0 \\
(0.0)\end{array}$ \\
\hline $\begin{array}{l}\text { The learning process never affected my } \\
\text { emotions. }(\mathrm{N}=69)\end{array}$ & $\begin{array}{r}7 \\
(10.1)\end{array}$ & $\begin{array}{r}20 \\
(29.0)\end{array}$ & $\begin{array}{r}13 \\
(18.8)\end{array}$ & $\begin{array}{r}26 \\
(37.7)\end{array}$ & $\begin{array}{r}3 \\
(4.3)\end{array}$ \\
\hline $\begin{array}{l}\text { My learning was enhanced through thinking. } \\
(\mathrm{N}=68)\end{array}$ & $\begin{array}{r}27 \\
(39.7)\end{array}$ & $\begin{array}{r}38 \\
(55.9)\end{array}$ & $\begin{array}{r}2 \\
(2.9)\end{array}$ & $\begin{array}{r}1 \\
(1.5)\end{array}$ & $\begin{array}{r}0 \\
(0.0)\end{array}$ \\
\hline $\begin{array}{l}\text { My learning was enhanced through feelings. ( } N \\
=69 \text { ) }\end{array}$ & $\begin{array}{r}12 \\
(17.4)\end{array}$ & $\begin{array}{r}34 \\
(49.3)\end{array}$ & $\begin{array}{r}12 \\
(17.4)\end{array}$ & $\begin{array}{r}10 \\
(14.5)\end{array}$ & $\begin{array}{r}1 \\
(1.4)\end{array}$ \\
\hline $\begin{array}{l}\text { My learning was enhanced by taking action. ( } N \\
=69 \text { ) }\end{array}$ & $\begin{array}{r}23 \\
(33.3)\end{array}$ & $\begin{array}{r}41 \\
(59.4)\end{array}$ & $\begin{array}{r}4 \\
(5.8)\end{array}$ & $\begin{array}{r}1 \\
(1.4)\end{array}$ & $\begin{array}{r}0 \\
(0.0)\end{array}$ \\
\hline $\begin{array}{l}\text { New learning was always connected to my } \\
\text { previous knowledge. }(\mathrm{N}=69)\end{array}$ & $\begin{array}{r}22 \\
(31.9)\end{array}$ & $\begin{array}{r}28 \\
(40.6)\end{array}$ & $\begin{array}{r}10 \\
(14.5)\end{array}$ & $\begin{array}{r}8 \\
(11.6)\end{array}$ & $\begin{array}{r}1 \\
(1.4)\end{array}$ \\
\hline $\begin{array}{l}\text { New learning had a transformative effect on } \\
\text { me. }(\mathrm{N}=69)\end{array}$ & $\begin{array}{r}24 \\
(34.8)\end{array}$ & $\begin{array}{r}32 \\
(46.4)\end{array}$ & $\begin{array}{r}11 \\
(15.9)\end{array}$ & $\begin{array}{r}1 \\
(1.4)\end{array}$ & $\begin{array}{r}1 \\
(1.4)\end{array}$ \\
\hline $\begin{array}{l}\text { Has improved my problem solving skills. }(\mathrm{N}= \\
69)\end{array}$ & $\begin{array}{r}27 \\
(39.1)\end{array}$ & $\begin{array}{r}36 \\
(52.2)\end{array}$ & $\begin{array}{r}5 \\
(7.2)\end{array}$ & $\begin{array}{r}0 \\
(0.0)\end{array}$ & $\begin{array}{r}1 \\
(1.4)\end{array}$ \\
\hline
\end{tabular}

Note. $\mathrm{SA}=$ strongly agree; $\mathrm{A}=$ agree $; \mathrm{N}=$ neither agree nor disagree; $\mathrm{D}=$ disagree; $\mathrm{SD}=$ strongly disagree; $\mathrm{n}=$ number of respondents; $\%=$ percentage of total number. 


\section{Research Question 7}

What are MIDA alumni perceptions of their transference of learning to the overall mission and work of their employing agency?

There were 13 items in the survey about the alumni contribution to the overall mission and work of their employing agency (see Table 15). The MIDA alumni indicate they greatly contribute to their employing agency with between $58.9-95.7 \%$ selecting Strongly agree and Agree answer options.

Table 15

MIDA Alumni Transference of Learning to Their Employing Agency

\begin{tabular}{|c|c|c|c|c|c|}
\hline & SA & $\mathrm{A}$ & $\mathrm{N}$ & $\mathrm{D}$ & $\mathrm{SD}$ \\
\hline Because I completed the MIDA ... & $\mathrm{n}$ & $\begin{array}{l}\mathrm{n} \\
(\%)\end{array}$ & $\mathrm{n}$ & $\mathrm{n}$ & $\begin{array}{c}\mathrm{n} \\
(\%)\end{array}$ \\
\hline I have grown professionally. $(\mathrm{N}=69)$ & $\begin{array}{r}44 \\
(63.8)\end{array}$ & $\begin{array}{r}20 \\
(29.0)\end{array}$ & $\begin{array}{r}4 \\
(5.8)\end{array}$ & $\begin{array}{r}1 \\
(1.4)\end{array}$ & $\begin{array}{r}0 \\
(0.0)\end{array}$ \\
\hline $\begin{array}{l}\text { I have the skills to look at development issues } \\
\text { more critically. }(N=69)\end{array}$ & $\begin{array}{r}42 \\
(60.9)\end{array}$ & $\begin{array}{r}24 \\
(34.8)\end{array}$ & $\begin{array}{r}2 \\
(2.9)\end{array}$ & $\begin{array}{r}1 \\
(1.4)\end{array}$ & $\begin{array}{r}0 \\
(0.0)\end{array}$ \\
\hline $\begin{array}{l}\text { I am better able to work as a team member for } \\
\text { my employing organization. }(\mathrm{N}=69)\end{array}$ & $\begin{array}{r}36 \\
(52.2)\end{array}$ & $\begin{array}{r}25 \\
(36.2)\end{array}$ & $\begin{array}{r}6 \\
(8.7)\end{array}$ & $\begin{array}{r}2 \\
(2.9)\end{array}$ & $\begin{array}{r}0 \\
(0.0)\end{array}$ \\
\hline $\begin{array}{l}\text { I am better able to produce practical, fundable } \\
\text { project grant proposals than before the } \\
\text { program. }(\mathrm{N}=69)\end{array}$ & $\begin{array}{r}27 \\
(39.1)\end{array}$ & $\begin{array}{r}31 \\
(44.3)\end{array}$ & $\begin{array}{r}7 \\
(10.0)\end{array}$ & $\begin{array}{r}3 \\
(4.3)\end{array}$ & $\begin{array}{r}1 \\
(1.4)\end{array}$ \\
\hline $\begin{array}{l}\text { I am more adaptable to the changing needs of } \\
\text { my organization. }(\mathrm{N}=69)\end{array}$ & $\begin{array}{r}30 \\
(43.5)\end{array}$ & $\begin{array}{r}31 \\
(44.9)\end{array}$ & $\begin{array}{r}6 \\
(8.7)\end{array}$ & $\begin{array}{r}2 \\
(2.9)\end{array}$ & $\begin{array}{r}0 \\
(0.0)\end{array}$ \\
\hline $\begin{array}{l}\text { I am more influential in helping the } \\
\text { organization I am employed by in fulfilling its } \\
\text { mission. }(\mathrm{N}=68)\end{array}$ & $\begin{array}{r}28 \\
(41.2)\end{array}$ & $\begin{array}{r}31 \\
(45.6)\end{array}$ & $\begin{array}{r}8 \\
(11.8)\end{array}$ & $\begin{array}{r}1 \\
(1.5)\end{array}$ & $\begin{array}{r}0 \\
(0.0)\end{array}$ \\
\hline
\end{tabular}


Table 15-Continued

\begin{tabular}{|c|c|c|c|c|c|}
\hline $\begin{array}{l}\text { I am able to produce higher quality professional } \\
\text { work. }(\mathrm{N}=69)\end{array}$ & $\begin{array}{r}33 \\
(47.8)\end{array}$ & $\begin{array}{r}31 \\
(44.6)\end{array}$ & $\begin{array}{r}3 \\
(4.3)\end{array}$ & $\begin{array}{r}2 \\
(2.9)\end{array}$ & $\begin{array}{r}0 \\
(0.0)\end{array}$ \\
\hline I have greater leadership potential. $(\mathrm{N}=69)$ & $\begin{array}{r}33 \\
(47.8)\end{array}$ & $\begin{array}{r}29 \\
(42.0)\end{array}$ & $\begin{array}{r}4 \\
(5.8)\end{array}$ & $\begin{array}{r}3 \\
(4.3)\end{array}$ & $\begin{array}{r}0 \\
(0.0)\end{array}$ \\
\hline $\begin{array}{l}\text { I am better equipped at completing an assigned } \\
\text { task. }(\mathrm{N}=69)\end{array}$ & $\begin{array}{r}34 \\
(49.3)\end{array}$ & $\begin{array}{r}27 \\
(39.1)\end{array}$ & $\begin{array}{r}5 \\
(7.2)\end{array}$ & $\begin{array}{r}3 \\
(4.3)\end{array}$ & $\begin{array}{r}0 \\
(0.0)\end{array}$ \\
\hline $\begin{array}{l}\text { My immediate supervisor has an understanding } \\
\text { of what I was taught. }(\mathrm{N}=68)\end{array}$ & $\begin{array}{r}20 \\
(29.4)\end{array}$ & $\begin{array}{r}27 \\
(39.7)\end{array}$ & $\begin{array}{r}9 \\
(13.2)\end{array}$ & $\begin{array}{r}6 \\
(8.8)\end{array}$ & $\begin{array}{r}6 \\
(8.8)\end{array}$ \\
\hline $\begin{array}{l}\text { The principles and concepts taught in the } \\
\text { MIDA program are ones I use on the job. }(\mathrm{N}= \\
68)\end{array}$ & $\begin{array}{r}25 \\
(36.8)\end{array}$ & $\begin{array}{r}26 \\
(38.2)\end{array}$ & $\begin{array}{r}10 \\
(14.7)\end{array}$ & $\begin{array}{r}5 \\
(7.4)\end{array}$ & $\begin{array}{r}2 \\
(2.9)\end{array}$ \\
\hline $\begin{array}{l}\text { My immediate supervisor encourages me to use } \\
\text { what I have learned from the MIDA program. } \\
(\mathrm{N}=68)\end{array}$ & $\begin{array}{r}18 \\
(26.5)\end{array}$ & $\begin{array}{r}22 \\
(32.4)\end{array}$ & $\begin{array}{r}19 \\
(27.9)\end{array}$ & $\begin{array}{r}6 \\
(8.8)\end{array}$ & $\begin{array}{r}3 \\
(4.4)\end{array}$ \\
\hline $\begin{array}{l}\text { My immediate supervisor expects me to put } \\
\text { into practice the things I have learned from the } \\
\text { MIDA. }(\mathrm{N}=68)\end{array}$ & $\begin{array}{r}20 \\
(29.4)\end{array}$ & $\begin{array}{r}28 \\
(41.2)\end{array}$ & $\begin{array}{r}11 \\
(16.2)\end{array}$ & $\begin{array}{r}7 \\
(10.3)\end{array}$ & $\begin{array}{r}2 \\
(2.9)\end{array}$ \\
\hline
\end{tabular}

\section{Research Question 8 and Null Hypothesis $\mathrm{H}_{0} 2$}

Are project cycle management, transformative learning, andragogy, course delivery, significant predictors of transference of learning mediated by experiencing individual capacity building to their organization? Null hypothesis $\mathrm{H}_{0} 2$ : Project cycle management, transformative learning, andragogy, course delivery, are not significant predictors of transference of learning mediated by experiencing individual capacity building to their organization.

The use of path analysis modeling has been utilized in many studies that have 
appeared in professional literature to show the interrelationships between the variables. Path analysis software develops (a) a graphic diagram that fits the data, (b) it shows the direct, indirect, and total effects of the different variables, and (c) it approximates the path of the different variable coefficients. A path analysis model elucidates the hypothesized relationships among variables in a way that multiple regression cannot. (Meyers, Gamst, \& Guarino, 2013). Meehl (1990) has put it this way “everything correlates to some extent with everything else" (p. 204).

Using the IBM ${ }^{\circledR}$ SPSS $^{\circledR}$ Amos $^{\circledR}$ (Version 7) software a capacity building path analysis model was developed using the six variables from the study: transformative learning, andragogy, course delivery, project cycle management, experiencing individual capacity building, and transference of learning. The model and the resulting path coefficients are shown in Figure 6.

Along with the graphic model data were generated that showed goodness of fit of the model, the coefficients of the direct, indirect, total effects, and levels of statistical significance. All the information pertaining to the correlations between all the variables were calculated simultaneously. All the correlations, except the transformative learning variable, are significant at the $p .001$ level.

A goodness of fit of the model with different indexes was calculated. The chisquare value for the model is $4.901(\mathrm{df}=4, p=.298)$ was not statistically significant. The non-significance of the chi-square indicates that the model fits the data well. The Normal Fit Index (NFI) for this model is .984 where a value of .9 or higher indicates a good fit (Wuensch, 2014). Overall this model symbolizes an excellent fit to the data. 


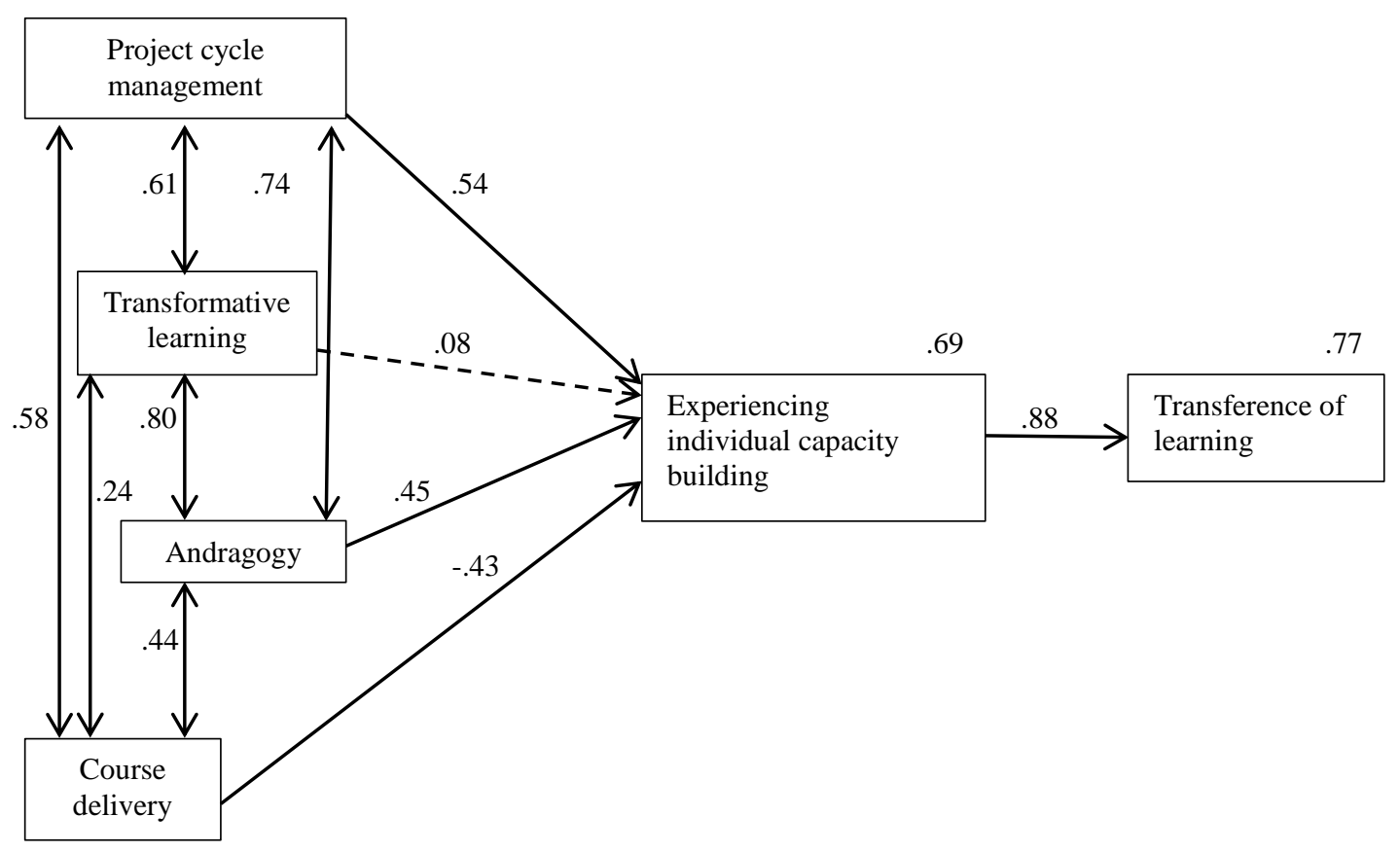

Figure 6 Path Analyses of the Study Variables

Note: Statistically significant $=\longrightarrow$ Not significant $=-\boldsymbol{-} \rightarrow$

Direct effects (endogenous) are those where one variable is directly predicting another (see Table 16). In this model direct effects are indicated by a unidirectional 1headed arrow. Endogenous variables can be either dependent or independent (Williams, 2015). This model reveals that three variables, "project cycle management," andragogy," and "course delivery," when looked at simultaneously, have a statistically significant direct predicting effect on the variable "experiencing individual capacity building." While the variable "transformative learning" is not statistically significant in its direct effect on the variable "experiencing individual capacity building." In turn, the “experiencing individual capacity building” variable has a coinciding statistically significant direct effect on the variable "transference of learning". 
Table 16

Summary of the Causal Effects of the Capacity Building Model

\begin{tabular}{|c|c|c|c|c|}
\hline & & & Isal Effe & \\
\hline Outcome & Determinant & Direct & Indirect & Total \\
\hline Experienced individual capacity & PCM & $.537^{* * *}$ & & .537 \\
\hline building & Andragogy & $.449^{* * *}$ & & .449 \\
\hline $\mathrm{R}^{2}=.696$ & Course delivery & $-.432^{* * *}$ & & -.432 \\
\hline & Transformative & & & \\
\hline & learning & .085 & & .085 \\
\hline Transference of learning & Experienced & & & \\
\hline $\mathrm{R}^{2}=.771$ & $\begin{array}{l}\text { individual capacity } \\
\text { building }\end{array}$ & $.878^{* * *}$ & & .878 \\
\hline & PCM & & .471 & .482 \\
\hline & Andragogy & & .394 & .451 \\
\hline & Course delivery & & -.379 & -.393 \\
\hline & Transformative & & & \\
\hline & learning & & .075 & .075 \\
\hline
\end{tabular}

Indirect effects (exogenous) are where a variable affects another variable through a mediating variable. The mediating variable for this model is "experiencing individual capacity building". The exogenous variables are "project cycle management," "andragogy," and "course delivery" because they work through "experienced individual capacity building" to indirectly "effect transference of learning". The indirect effect is the product of the coefficients of an exogenous and a mediating variable (Wuensch, 2015). For example; the coefficient of project cycle management (.537) is multiplied by the coefficient of experiencing individual capacity building $(.878),(.537 \times .878=.471)$. Exogenous variables are always independent (Williams, 2015). The summation of the 
direct and indirect effects will give the total effect for each of the variables involved within the model (see Table 16).

The correlations between exogenous variables are represented by a bidirectional 2-headed arrow with their own path coefficients going from one exogenous variable to another, signifying correlation between two variables. A 2-headed arrow never connects directly with an endogenous variable. This model indicates that the exogenous variables project cycle management, transformative learning, andragogy, and course delivery have an effect upon each other (see Table 17).

The purpose of this path analysis was to test the relevance of a particular causal structure. It was important to recognize the direct effect unambiguous variables had on the outcome variables, and also ascertain the indirect effects each exerted throughout the causal scheme. It was also important to determine whether or not this particular causal scheme was of practical significance so that it can be used, with a reasonable degree of confidence, to compare with the theoretical logical framework of this dissertation.

The $\mathrm{R}^{2}$ values reported in Table 16 show that "project cycle management," "andragogy," "course delivery," and "transformative learning" contributes $69.6 \%$ to the "experienced of individual capacity building". And the sequence of influence is passed on to "transference of learning" of $77.1 \%$ by the indirect and direct effects of the other four variables in the causal stream. This international development capacity building path analysis model is very good to excellent in demonstrating the causal scheme of the different variables in building capacity in the alumni of the off-campus international development program of Andrews University. It does not affirm the proposed path analysis (Figure 1) as a casual correlation model of project cycle management, 
Table 17

Summary of the Correlations of the Exogenous Variables of the Capacity Building Model

\begin{tabular}{lc}
\hline \multicolumn{1}{c}{ Exogenous Variables } & Coefficients \\
\hline Andragogy $\leftrightarrow$ Course delivery & .440 \\
PCM $\leftrightarrow$ Andragogy & .737 \\
PCM $\leftrightarrow$ Course delivery & .583 \\
Transformative learning $\leftrightarrow$ Andragogy & .797 \\
Transformative learning $\leftrightarrow$ PCM & .606 \\
Transformative learning $\leftrightarrow$ Course delivery & .237 \\
\hline
\end{tabular}

andragogy, transformative learning, and course delivery that leads to transference of learning.

\section{Research Question 9}

What are the MIDA alumni thoughts and opinions of the off-campus Andrews University Master in International Development Administration in terms of strength(s), areas for improvement, and opportunities for meeting current and future international development needs?

Three different open-ended questions (See Appendix B, MIDA Alumni Survey, $56,57 \& 58)$ in the survey dealt with each of the topics in this research question: (1) strengths of the program, (2) areas for improvement in the program, and (3) where the MIDA program can meet the present and future needs of the international development community.

The use of an open-ended question forum gave the alumni a voice to critique the MIDA program while still remaining anonymous. Actual names have been replaced with pseudonyms for all direct quotes. All of the alumni's word-for-word unedited remarks 
can be found in Appendix F.

Common "themes" from the responses were identified. Comparable comments were grouped into each of these themes. Selected direct quotes will lend authenticity to how the program affected the MIDA alumni both professionally and personally, while adding important information on the strengths, areas of improvement, and how the program can meet the current and future needs the international community at-large.

\section{Strengths of the Program}

As you look back on your educational experience with the off-campus graduate program in international development offered by Andrews University, what would you say were the strengths of the program?

Sixty of the $70(85.7 \%)$ respondents wrote comment(s) to this question. Of the three open-ended questions this one received the highest response rate.

There were five main themes that could be separated out from the alumni comments to this question. The five themes in descending order according to the number of comments made are: (1) professors in the program, (2) thoughts on fellow students, (3) practicality of the program, (4) learning dimensions, and (5) advantages of the program.

The alumni had high regard for the professors, instructors, concentration mentors, and the director of the MIDA program. The alumni thought the professors had realistic knowledge and were well experienced in the different areas they taught. The professors used real life experiences as part of their class instruction to engage the learner. Ruth commented "(The) professors were very skillful and on-top of the subjects/topics." They also liked the diversity of the staff and their professional background. There was "close 
interaction between instructors and students" observed William.

The second area the alumni made comments about were about their fellow students. They liked the fact that the other students in the program were also practitioners in some area of international development. The varied experiences, cultures, values, knowledge, and interaction with fellow students in the classroom had positive learning aspects to it. As Joseph put it "It brought together people from various backgrounds, with differing levels of experience and we were able to learn from each other."

The third area the alumni thought was strength of the MIDA program was the "practical relevance to the field work" responded Alisha. Several of the alumni said the program was "very practical." They appreciated the fact that they could immediately apply the concepts taught in the classroom to their work back in their home employing agency. Gina said that the program "gave the learners an opportunity to practice what they were learning through the various assignments." Possibly Scott articulated it best "we learned, (and) then we practiced what we learned."

A fourth area that could be associated with the practical aspect of the program was the learning dimension. The alumni thought the classes were well organized, very interactive not only between the professors and the students, but also the student-tostudent openness of "experience sharing", "group assignments," and the "group dynamics" that were fostered. "We discussed real life issues and learned from them" observed Mick. The reading materials and resources were current, and for the most part relevant to the subject being taught. "This was the best course I ever attended" responds Esther, for it was "well delivered and managed."

The last area that the alumni thought was a real strength of the MIDA program 
was the opportunity it gave them to obtain a higher degree without a break in their employment. For many this was a great advantage. On the whole the alumni appreciated the flexibility of the program to meet their needs as working adult learners. It was more affordable when compared with the on-campus program, and for the most part the teaching sites were close to where the participants lived. Charles said he started the program as a program officer and after he finished the program he was promoted to being a country director, "It enabled me to achieve my goals and the goals of ADRA successfully."

From this thematic analysis on the strengths of the MIDA program the alumni had positive thoughts and good feelings about the program they were a part of for five years. As Jennifer so aptly puts it, "The information that I got there has been so valuable to build my future."

\section{Areas for Improvement in the Program}

As you look back on your educational experience with the off-campus graduate program in international development offered by Andrews University, what would be your recommendations on how the program could be improved?

There was a $78.6 \%$ (55 of 70) response rate with this survey question. There were five main themes that could be collated from the comments the alumni wrote upon for areas of improvement in the program. In descending order according to the number of comments made for each topic included: (1) course work and related topics, (2) comments on the professors, (3) academics, (4) Andrews University, and (5) fellow students. 
The responses to this question were at times difficult to analyze and/or categorize into themes. Some of the ideas that were being expressed were cryptic and not fully developed. In several areas there were contradictory statements that left me puzzled as to what the alumni were trying to convey when compared with what they said about the strengths of the program.

The course that received the most comments was statistics. Archie felt it should not be in the program because it was "helpful for a business major but not for international development." While others thought that the course needed to be "stronger," "improved," and "more easy to understand." Lois said "increase the practicality" of the class.

Another area to which a couple of alumni talked about was research. One felt that there needed to be more "detailed presentation of research methodology." While Joan commented that "more teaching (on) how to actually conduct the final research (project)." While another felt there needed to be more time to be able to do "reading and research."

Several thought there needed to be a stronger emphasis on faith and development work. Bob wondered "how do they interrelate?"

The second area that had the strongest critics was the professors that taught the classes. One of the alumni, Joseph, felt that a certain professor was an "embarrassment to the program." This was due to lack of adequate class preparation or depth of knowledge on the topic being taught. While several alumni felt that the some of the instructors lacked field experience and approached their topics as academics, not practitioners. Another area of criticism concerned the research concentration mentors. Duane 
said "I had (a) very very hard time to find (a) mentor for my research project." It took Andrews University a long time to find a research mentor for him. For one alumnus the program needs to "rethink about the person who walks the student(s) through the research paper" process. For that person it was a "frustrating experience."

The third grouping of comments I call academics. There were several comments on having some of the course work be on-line. Also the aspect of having a $\mathrm{PhD}$ in international development be created.

Sam thought the whole program could be shortened to 3 or 4 years, instead of 5 years. Mabel felt that there should be more sessions per year to get through the program faster.

Some of the courses were "crowded" as far as the number of people in the class. While Andrew thought some classes needed more time to be "internalized."

Gary felt that the "lack of text books in the African site when the European site had them" made it difficult for the students at the African site to obtain the knowledge they needed in the class that was being taught.

The fourth area in which the program could be improved from the alumni perspective dealt with Andrews University. There were a number of individual comments in regard to Andrews University.

Louise questioned why it should take six months for her to receive "my scores for the final exam(s)." A source of frustration is why Andrews University does not "charge fees in local currency."

Milly suggested that an "off-campus site needs to be established in the Caribbean/South America area.” 
The fifth area that the alumni made comments about was about their fellow students. Henry questioned the motive of some of his fellow alumni for why they took the MIDA program. He asked "How many ADRA participants went on to leave ADRA soon after receiving the degree for higher paying jobs with other organizations?”

Another area of concern about the program was that students who were accepted in to the program "should be focused on people who are working, not those who haven't started working."

The comments made where the MIDA program could be improved are from alumni who probably care about the program and should be taken in that context. The suggestions made could be beginning talking points that the administrators of the program could possibly look at and study on trying to improve the quality of the program.

\section{Present and Future Needs of the International Development Community}

As you look back on your educational experience with the off-campus graduate program in international development offered by Andrews University, how could the program be strengthened to meet the present and future needs of the international community?

The response rate for this open-ended question was 78.6\% (55/70). Many of the comments to this question have already been mentioned in the two previous open-ended questions, even though the questions themselves have different intents. The survey responses were from a random sample of MIDA alumni and it is presumed that no one MIDA alumnus knew how another alumnus would respond to a question. Therefore, any observations made by the alumni in response to this question, even if a similar answer is 
found in a previous question, will be treated as if they were first time responses.

There were six main themes that were classified from the responses to this question. The area that had the most suggestions is what I call program enhancement. The other themes included: (2) development issues, (3) learning dimensions, (4) fellow students, (5) learning materials, and (6) odds and ends.

In the area of program enhancement there were a number of calls for Andrews University to begin an off-campus $\mathrm{PhD}$ program in the area of international development. Adam thought this would help meet a "manpower" vacuum in the different countries where the alumni work.

Another concern, which is an antithesis of the strengths of the program found in the first open-ended question, was to be more practical in their pedagogical approach to international development. "Offer more practical hands-on experiences and less theoretical" classes offered Julie. Noah felt that it was a waste of time for the professors to require "them (to read) some journal article" and prepare a "power point presentation" about the article. Chrissy's take on what it meant to be practical was "that the participants submit an actual" well written and planned "proposal/grant to an agency for funding" as a requirement for graduation.

There was a general feeling among of several of the students that there needed to be a "continuously" updating within the program with "current development practices." John had a several thoughts on this topic (1) "best practices in branding," (2) "digital media communications," and (3) "fundraising and constituent engagement would be vital for a well-rounded program." Gerald believed adding "components of peace building and conflict mitigation, emergency preparedness and response, and international humanitarian 
law" would be a good idea. Mandy thought that a course in developing "leadership skills" was important.

The second theme dealt with development issues. One of the areas of concern was "how to how to handle political challenges that hamper development." This next issue, which could be part of the previous paragraph, comes from Bernice on "how we can find the proper ways to approach or convey our needs in a diplomatic and culturally correct manner." Daniel presented the idea on how the MIDA program should be helping the students look "for the big issues in the world," who are the people "making strides" in the community of international development, "and helping people really realize their basic human rights." Mary pondered about the issues of "displaced people" refugees "and human trafficking" that were not being talked about.

A third area of improvement had to do with learning dimensions. Joel made the observation the professors who taught within the program needed to have "updated knowledge about developing countries (especially countries in Asia)." He felt that the examples given in the class about international development "were about Africa only."

To add to the learning dimensions component was the thought of using practitioners from other NGO's besides just ADRA personnel to possibly teach or be a part of the teaching staff. And coupled with this thought from Margareta was that "world development work should be shared during course(s) as learners come from different countries."

Comments about their fellow students were the fourth concern of some the alumni. Peter was very adamant about the fact that "the quality of writing of some of the graduates" left "a lot to be desired." He felt that a basic requirement for being in a 
graduate program was to have competency in "quality writing skills."

A second worry on the subject about their fellow students was "the program should continue its first practices of admitting people with field experience and not (accept) candidates without (field) experience." Paul gave the following advise "be more selective of the students/candidates" because he felt "many of my peers did not have the education(al) requirements, to join the program."

There were a few brief comments about the learning materials used in the program. Eve had the opinion that "the training material need to recognize the changes" and be "on the cutting edge," and current. Some of the alumni also thought that the use of new technologies was important.

The last area for improvement I have named odds and ends, because the comments submitted do not go into a particular place. For instance, Steven suggested that MIDA “offer job opportunities whenever an opportune knocks such as ADRA, World Vision etc." One proposal from Heather was that scholarships be made available to qualified students so that the cost of the program could be lessened. A couple of alumni proposed that refresher courses be offered at an "affordable fee" from time-to-time by Andrews University.

\section{Research Question 10}

What are the MIDA alumni thoughts and opinions of the off-campus Andrews University Master in International Development Administration of important courses or concepts that need to be included in the curriculum, or important concepts or principles that they learned from the program? 
Two different short answer open-ended questions (See Appendix B, MIDA Alumni Survey, $54 \& 55$ ) in the survey dealt with each of the topics in this research question: (1) what course or concepts need to be included in the curriculum of the MIDA to improve it and/or keep it relevant, and (2) what were the most important concepts or principles that you learned from the MIDA.

\section{Concepts/Principles that Need to be Included in the Curriculum}

The work in the international development community is dynamic and ever changing. In your opinion what are the three (3) courses or concepts need to be included in the curriculum of the MIDA to improve it and keep it relevant?

Forty-nine of the seventy (70.0\%) alumni responded to this inquiry. Four different themes were collated from the responses. In descending order according to the number of responses per theme: course work already in the MIDA program, development issues, humanitarian issues, and communication.

Course work already in the MIDA program was one of the themes that were garnered from the responses of the alumni. I can surmise that some of the alumni may not have thoroughly understood the question, or they felt that these concepts or courses needed to have a stronger emphasis, or possibly the students themselves thought they needed to have a deeper understanding of those concepts or principles.

The area of economics gathered some of the highest number of remarks. This included courses or concepts in micro/macroeconomics, finances (financial analysis, financial management, financial sustainability of NGOs, program financing, economics and politics of (foreign) aid), accounting, budgeting and fund raising. 
Several alumni mentioned monitoring and evaluation (M\&E). Clive thought there should be more emphasis on "participatory evaluation methods." Deborah put forth the idea of the "processes and tools" needed in M\&E.

Proposal writing (also named grantsmanship) and needs assessment were other concerns of the alumni. Organizational behavior, team building, governance, and human resource management were also listed.

Disaster management is another subject that is already in the program, but alumni made some comments about it. Saul thought that "emergencies were on the increase" and more international development professionals should be engaged. More leadership in emergency preparedness and response should be a "focus" in these courses.

The second theme was in development issues. Jacob and Mary felt that concepts about the environment/climate change needed to be addressed. While Judy thought that "ethics in development work" was important. Suzy had the opinion that making the "transition from relief (work) to development (work)" is an important issue that needs to be discussed. Several still wondered about theories of development and participatory development approaches.

The third suggestion dealt with humanitarian issues. This was the most diverse in the kinds of responses the alumni wrote about. The topic that gathered the most comments were about security issues. Ed thought a course on peace education should be a part of the curriculum. Sharon felt concepts of peace building and mitigation should have a priority. Along the same line Erin spoke about an in-depth discussion of "conflict resolution" was needed. While Duane wrote the impact of "terrorism on the development process" should be an important focus. 
Another issue within this area was human rights. Patty felt that more weight needed to be focused on gender and "violence against women." Seth felt that "a framework for intervention" for working with kids needed to be pursued.

Humanitarian and international law were suggested matters that were important to Bart and Paul. Topics would include social issues in globalization and international development, international relations and development, and international politics.

The fourth area of concern was in the use of communication and the international development practitioner. Cory believed networking within the "NGO environment" needed to be improved. Overall Nathan sees the "role of social and digital media" is important to "engage both constituents and investors," and to maintain good "donor relations" for development.

\section{Important Concepts/Principles Learned from MIDA}

In your opinion what were the three (3) most important concepts or principles that you learned from the MIDA?

This survey question elicited 54 out of possible 70 (77.1\%) alumni responses. Thirteen items or themes were separated out from the written comments. In descending order according to the number of responses per theme: organizational behavior, anthropology, proposal writing, monitoring and evaluation, PCM, needs assessment, research, communication, sustainable development, project management, finances, ethics in development, and critical thinking.

From the alumni perspective organizational behavior, which deals with concepts of management, was by far the most important concept or principle that they learned or 
were exposed to. There were several sub-themes that the alumni directly mentioned. Team work or team building was an important concept for Seth. Reagan deemed "leadership" as vital for an organization. However Dale put forth the idea of the management of the human resources was necessary to properly maintain order within the organization.

The number of comments from the alumni on the second theme of anthropology was almost as large as organizational behavior, but they were much more varied. Lynda felt that the class dealing with anthropology as a subject was important. Several of the alumni appreciated the idea of what local or indigenous knowledge was and what it could bring to the development process. The idea of thinking from a "global" perspective but acting on a "local" level was a new hypothesis for Ruthann. For Mikal the term “grassroots partnerships" was revealing from an anthropological viewpoint.

Proposal writing sometimes referred to as grantsmanship or project writing was an important concept to learn for the alumni.

How to monitor and evaluate a project was also a central part of the alumni learning to increase their individual capacity building.

Another area for alumni capacity building was in needs assessment. This course helped the alumni to "assess the needs of the community" for possible development interventions.

The research process was a new experience for many of the alumni. The use of different research methodologies, statistics, and their own self-development in research writing was a challenge to most of the alumni.

The use of communication in "development practices" was another concept that 
was of value to the alumni. Understanding the role of "intercultural communication" for Sammy was an important idea for him.

Sustainable development is the thought that after the funding for a development project has ended the community/family/individual would be economically selfsustaining in carrying out the goals and objectives of the project without outside resources. Doug felt that this was a crucial "development paradigm."

Project management was another course the alumni thought was an essential part of their learning process.

Even though finances are part of the PCM process the alumni singled it out as a theme unto itself. Learning about financial analysis, reporting, and budgeting were significant for them, and to where it fit in the whole scheme of development. Different aspects of the banking structure and foreign exchange were fundamental for Alicia to comprehend.

Ethics in development had a small number of mentions, but for several of the alumni it was a weighty part of their learning process as adult learners.

The last theme has to deal with critical thinking. Margo felt that "reflections" helped "shaped my way of thinking." The use of logic model ideas was imperative as part of the critical thinking process for Rueben. 


\section{CHAPTER 5}

\section{EVALUATION FINDINGS, THEORY DEVELOPMENT, DISCUSSION, AND RECOMMENDATIONS}

\section{Background}

There exists a very limited body of research on the importance and effect of education in international development when it comes to building the capacity of the practitioners of international development. The graduates of the off-campus Master of International Development Administration of Andrews University were asked, via a survey, to share their perceptions of this program, how it affected their professional and personal growth in the area of capacity building, and how they transfer their learning to their work in the international development community. The impetus for this study came from the fact that there had never been an extensive investigation of the capacity building impact of this graduate educational program on the graduates. "Only where there is a sufficiently broad basis of critically sifted data can inductive reasoning lead to sound generalizations" (Albreight, 1957, p. 26).

\section{Purpose of the Study}

The purpose of this study was to investigate alumni perceptions of the quality of the off-campus Master in International Development Administration program of Andrews University, its capacity building effect(s) on the alumni and the alumni's perceptions transference of their learning to the organizations that employ them. The purpose of this 
the study is best understood through its four main sub-objectives: (a) to ascertain if alumni believed they developed individual capacity to function more effectively and efficiently because of their participation in the MIDA program, (b) to evaluate from the alumni's perspectives the academic strengths and challenges of the MIDA curriculum in the context to capacity building in the field of international development, (c) discover what can be learned from this off-campus program and how Andrews University can apply these lessons to this and other off-campus graduate programs, and (d) test the theoretical model underlying the MIDA program to measure its impact on alumni perceptions of transference of learning to their international development work.

\section{Related Literature}

This summary of the literature was organized around five general themes: learning theories, international development, capacity building and education, alumni surveys in academia, and the theoretical framework for this study.

\section{Learning Theories: Andragogy and Transformative Learning}

All humans go through distinctive stages of development throughout their life. Each stage, prenatal to older adults, reveals that humans are a complex interaction of the mental, physical, social, (Santrock, 1992) and spiritual (White, 1903). Generally the way people learn is affected by what stage of life development they are in.

Starting in the late 1960's a focus has been on the "art and science of helping adults learn" (Knowles et al., 2005) as opposed to pedagogy that dealt with how children learned. The theory of how adults learn is called andragogy. 
According to Knowles, and others who have been involved in andragogy research, have suggested that there are six basic principles to this theory. Briefly these concepts are: (1) adults need to know why they need to know to learn, (2) self-concept as self-directed or independent in their choices of what to learn, (3) their life experiences are a resource for learning, (4) willingness to learn when faced with real-life circumstances, (5) adults are more interested in problem -solving than subject learning, and (6) the motivation to learn is more internal than external (Knowles et al., 2005; Merriam et al., 2007).

Another view about learning put forth by Peter Jarvis (2006) is that when adults learn it transforms their whole being. He proposes that individuals are transformed through three dimensions of the interaction of thinking, feeling, and acting. This is transformative learning. Learning is a holistic phenomenon. Jarvis in his book Towards a Comprehensive Theory of Human Learning explains transformative learning theory. He proposes that a person is in a steady state where no conscious learning is taking place. Then "an episodic experience" or "disjuncture" (p.17) takes place that disturbs this steady state. If this episodic event is rejected the person goes back to their original steady state and no learning has happened. On the other hand if the initial disturbance in the steady state is transformed and internalized into new "mental meaning" (p. 22) learning has taken place that transforms the person in both mind and body. When this new mental meaning becomes a normal part of a person's biography it becomes the new steady state until the next episodic event. This transformative learning process occurs over time. (See Figure 2) 


\section{International Development}

Even though there have been international relations and trade for hundreds, if not thousands of years, only in the last half of the $20^{\text {th }}$ century and into the present has the focus been on international development, the "era of development" (Thomas, 2000, p. 5).

The concept of development entails the idea of growth, change, or progress in the human condition. When it is linked with the term international it is within the construct of general human development that also enfolds economic and social progress which is humanitarian in its outreach through the actions of poverty reduction, education, water, and food security, gender equality, and governance (Greiman, 2011). Therefore international development is where developed countries help impoverished communities and countries out of poverty, and raise their standard of living throughout all levels of society.

\section{Education and Capacity Building}

Knowledge is increasingly being recognized as an asset or commodity in the international development community and should be used to benefit society (OECD, 2001 and Crossley \& Holmes, 2001). For the international development practitioner this acquisition of knowledge can occur through several avenues which can lead to capacity building of the individual: in-service seminars and workshops, internships, on-the-jobtraining, work experience, and formal education. Whatever approaches are used, capacity building is a long-term commitment "measured in years" (Wing, 2004, p. 157).

For this study capacity building was defined for the international development practitioner in the context of participation in a graduate educational curriculum in 
international development. Individual capacity building is the process of developing new skills and critical thinking practices to augment and build on prior learning, and professional life experiences. Individual capacity building has the power to improve the work and efficacy of organizations, thus enhancing the dignity and quality of human development, which affect all levels of society. For Crocker and Schwenke (2005) human development is the goal of international development instead of "humans being an instrument of development" (p. 8).

An important goal of capacity building in the field of international development is to promote sustainable development. But the usefulness or effectiveness of capacity building has been problematic to quantify (UNEP, 2000). In studying capacity building projects it funded the World Bank has determined that even though a person may have personally benefitted from a capacity building training program, participation in the program was a poor predictor of carryover performance into the workplace (Chin, 2008).

From their own evaluation of capacity training programs, the World Bank found that there were three important factors that should be incorporated into the design of a training program. The first was solid pedagogy. This included professionally tailored curriculum to meet the training needs of the audience being trained, along with a variety of didactic training methods. Second, action-learning and practice to implement the capacity building learning of the classroom to the work environment. Third, target the training to meet the organization's needs.

The Use of Alumni Surveys

Since the 1930's institutions of higher learning have been conducting surveys of 
their alumni. These early surveys dealt mainly with transition from academia to the workforce (Cabera, Weerts \& Zulick, 2005). From the 1980's the focus of the surveys have included assessment of student learning, interpersonal communication skills, and the influence of the institution on the development of critical thinking skills (Borden, 2005; Cabers et al, 2005; Ewel, 2005).

Hoey and Gardner (1999) found that the use of surveys try to assess the "knowledge, skill and abilities that connect the academy to the (real) world of work" (p. 44). These types of survey's evaluates the knowledge and skills acquired by the alumni from their university or college for assessing the significance of the academic curriculum to the changing needs, demands, and expectations of the alumni's work profession.

\section{Theoretical Framework for Study}

The theoretical framework proposed in this study is a systematic cyclical causeeffect approach to capacity building in international development. The chain of events within this framework is input, process, output, measurable outcomes, performance, and impact. As Eade (1997) points out capacity building is not neutral in its effect and it is a process that is multi-dimensional, and multi-directional. The ripple influence of capacity building impacts function and performance at all levels (LaFond \& Brown, 2003).

Within the setting of international development I have identified three main areas that describe the basis of this theoretical framework: (1) the international development practitioners, (2) organization, and (3) society (see Figure 4). The first area forms the foundation for this study, the alumni's perceptions of experiencing individual capacity building and the transference of their learning to the international development 
community. A study of capacity building and its long-term effect upon the international development organization, and in society is beyond the range of this dissertation due to limited time and resources.

\section{Methodology}

This investigation used an explanatory ex-post-facto quantitative methodology design. Ex-post-facto design allows the exploration of possible causal relationship between variables after the event(s) has taken place. Thus the event(s) cannot be manipulated by the researcher (Newman et al., 1997). As the survey questionnaire contained some open-ended response items, there are elements of qualitative data and analysis within the research design.

The dependent variables for this study are "project cycle management," "transformative learning," "andragogy," "course delivery," "experienced individual capacity building," and "transference of learning" to the international development work setting. The independent variables are "gender" and "present age".

The population for this study is the alumni of the off-campus Master of International Development Administration program of Andrews University. This program was offered in four languages (English, Spanish, French, and Russian) but the survey was delimited to those alumni who took their course work in English.

A survey instrument was developed by the writer using Survey Monkey ${ }^{\circledR}$. A number of pilot studies were undertaken to obtain suggestions on how the instrument could be improved before it was sent out to the study population. The survey asked the alumni to share their perceptions of the off-campus international development offered by 
Andrews University. The first part of the survey was demographic in nature, the second part used a 5-point Likert-scale with categories ranging from strongly agree to strongly disagree, and the third part included the open-ended questions. The surveys were sent out by email with an accompanying cover letter to the alumni inviting them to participate in the study.

Once the surveys were returned and the process of data cleaning was accomplished statistical analysis was conducted. The analyses showed the similarities, differences, and interrelationships of the dependent and independent variables as perceived by the survey respondents.

Because this is an ex-post-facto design methodology both descriptive and inferential statistical analyses were applied. Descriptive statistical analysis is the "most fundamental" (McMillian \& Schumacher, 2001, p. 207) to summarize and explain data. It shows central tendency and measures the spread of the data. Inferential statistics can be used to make predictions, conclusions and generalizations from the randomly chosen sample (McMillian \& Schumacher, 2001).

Two-way MANOVA and path analysis were used to test the stated hypotheses. These statistical analyses determined if similarities, differences, and interactions (causality) existed in the graduates' perceptions of the international development program related to gender and present age. The open-ended questions were analyzed thematically.

\section{Major Findings of the Evaluation Study}

Demographics

Due to the nature of the off-campus program in international development with 
MIDA alumni being scattered throughout the world this survey was delivered electronically by email. Alumni email addresses were obtained from the off-campus International Development Office located on the campus of Andrews University. In total 307 emails were sent out but 100 (32.6\%) were undeliverable and 207 (67.4\%) were deliverable. From the first mailing there were 35 (19.91\%) responses. In a second mailing there were $18(8.70 \%)$ more responses, bringing the total to $53(25.60 \%)$. With two more follow up requests the total number of responses came to $70(33.82 \%)$. The survey requests were sent over a period of six weeks with a total of eight weeks for the alumni to respond to the survey requests before the survey was closed.

From the 70 responses there were $38(54.3 \%)$ females and $32(45.7 \%)$ males with a mean age of 45.5 years. The alumni who answered the surveys were on the average 6 years past graduation. This would suggest that the alumni respondents were established in their professional careers, and had time to reflect on how the MIDA program influenced their personal and professional lives.

There were two different demographic questions that dealt with the same topic but at different times in the alumni's professional career: the type of organization they worked for at the time they began the MIDA program compared with the type of organization they work for at the time they answered the survey. Over half the alumni who worked for faith-based organization at the time they entered the program (23 out of 54 respondents) moved away from working for faith-based organizations to government, private NGO's, other organizations (education, private business, and clergy) after their graduation from the MIDA program.

Many of the alumni (71.0\%) said they had higher levels of responsibility now in 
the professional careers than when they entered the international development program. Over $94.0 \%$ of the alumni would recommend the MIDA program to their fellow colleagues or friends.

\section{Inferential Analyses}

Research question 1: Do differences exist by gender and present age in MIDA alumni perceptions of individual capacity building, course delivery, project cycle management, andragogy, transformative learning, and transference of learning?

Null Hypothesis $H_{0} 1$ : There are no statistically significant differences by gender and present age in MIDA alumni perceptions of individual capacity building, course delivery, project cycle management, andragogy, transformative learning, and transference of learning.

A two-way MANOVA of the six dependent variables and the two independent variables indicated that there were no significant interaction effects between gender and present age $F(30,206)=1.170, p=.259$, Wilk's $\Lambda=.533$. A Between-Subject effect also revealed that there were no significant differences based on gender or present age.

Therefore, the null hypothesis $\mathrm{H}_{0} 1$ is retained that there are no significant differences by gender and present age in MIDA alumni perceptions of individual capacity building, course delivery, project cycle management, andragogy, transformative learning, and transference of learning.

\section{Frequency Analysis}

Research questions 2-7 are answered using frequency analysis of each of the items within the individual dependent variables of the study. 
Research question 2: What are the MIDA alumni perceptions of experiencing individual capacity building while in the program?

Seven items in the survey evaluated the MIDA alumni perceptions of experiencing individual capacity building while studying in the program. After combining the strongly agree and agree responses, for these seven items $92 \%$ of the alumni concurred that the program helped build their capacity individually in international development. From the alumni perspective the program achieved its goal of developing capacity in international development professionals it served.

Research question 3: What are MIDA alumni perceptions of the effectiveness of the teaching, learning and course delivery processes used for this program?

There are 23 items in this variable about course delivery. Overall the alumni were pleased with the how the courses were delivered, the efficacy of the teaching, and the learning experience with a range of 59-95\% of alumni indicating strongly agree or agree for 21 of the 23 items. There were two items that the alumni were not positive about on their opinion of their fellow students. The alumni had combined percentage of disagree or strongly disagree that $68.1 \%$ of the students did not having equal knowledge in international development, and $70.1 \%$ of their fellow students did not have equal experience in international development.

Research question 4: What are MIDA alumni perceptions of using project cycle management to organize the program curriculum?

The MIDA alumni perception of using project cycle management as the core of the curriculum was very high in most of the 12 items within this variable. Most of the combined percentages of the strongly agree and agree ranged from the low to mid 90 's, 
with one exception of almost 84\% (83.6-95.6\%). The item about using PCM as good approach to learning team building rated the lowest percentage.

Research question 5: What are MIDA alumni perceptions of the use of andragogy in the program.

Ten item questions were asked in this variable on andragogy. The students perception of the principles of andragogy as part of the teaching and learning within the MIDA program was $78.2-92.8 \%$ of the pooled strongly agree and agree answer options in the survey. The motivation to learn had the lowest percentage.

Research question 6: What are MIDA alumni perceptions of the inclusion of transformative learning in the program?

Most of the ten items within this variable of the inclusion of transformative learning into the program curriculum ranged from $66.7-95.6 \%$ of the strongly agree or agree responses. One item statement asked about how transformative learning affected their emotions was more diverse. The strongly agree or agree combined percentages were $39.1 \%$, while the combined disagree or strongly disagree percentages were $42 \%$, with $18.8 \%$ were neutral about transformative learning affecting their emotions.

Research question 7: What are MIDA alumni perceptions of their transference of learning to the overall mission and work of their employing agency? The alumni's own perceptions of their transference of their learning from the MIDA program to the organizations they work for are 58.9-95.7\% of the joined strongly agree and agree answers. A little over $86 \%$ of the respondents perceived they had transferred learning to their organization, while $13 \%$ had not. The three items about their supervisors within their work organization had the lowest combined percentage of strongly agree and 
agree answers. The lowest percentage (58.9\%) the alumni gave to their supervisor of them being encouraged to use what they learned from the program. The other two lower percentage were almost equal (69.1\%) for the supervisor understanding what the alumni were taught, and (70.6\%) for the supervisors expectations of the alumni to put into practice what they learned.

\section{Path Analysis}

Research question 8: Are project cycle management, transformative learning, andragogy, course delivery, significant predictors of transference of learning mediated by experiencing individual capacity building to their organization?

In multiple linear regression (MLR) language the Null hypothesis $H_{0} 2$ is: Project cycle management, transformative learning, andragogy, and course delivery, are not significant predictors of transference of learning mediated by experiencing individual capacity building to their organization.

Using IBM $^{\circledR}$ SPSS $^{\circledR}$ AMOS $^{\circledR}$ software a capacity building path analysis model (see Figure 7) was created using the four exogenous variables and the two endogenous variables. All the data connected to the correlations among the variables were calculated simultaneously. With the exception of transformative learning, all the correlations were statistically significant at the $p .001$ levels.

Along with the correlations a goodness of fit of the path analysis model was calculated. The calculated chi-square for the model was not statistically significant (5.447, $\mathrm{df}=5, p=.364)$ with a Normal Fit Index (NFI) of .982. This represents an excellent fit to the data, and indicates the need to retain the hypothesis that states the 
theoretical model covariance equals the data matrix. Therefore in MLR language the null hypothesis $\mathrm{H}_{0} 2$ is rejected that project cycle management, transformative learning, andragogy, course delivery, are not significant predictors of transference of learning mediated by experiencing individual capacity building to their organization.

\section{Open-Ended Questions Analyses}

The last two research questions were answered by the alumni with the use of open-ended questions. The open-ended question format gave the alumni an opportunity to voice their thoughts about, perceptions of, concerns about, and suggestions for improving the Master of International Development Administration of Andrews University. The open-ended format allowed alumni to respond without the stricture of pre-formulated items found in the Likert-scale and demographic questions.

Research Question 9: What are the MIDA alumni thoughts and opinions of the off-campus Andrews University Master in International Development Administration in terms of strength(s), areas for improvement, and opportunities for meeting current and future international development needs?

In the strengths of the program there were five major themes that the alumni wrote about. The first was that the professors were well experienced in the various subjects or topics that were being taught, and there was excellent rapport and interaction between the instructors and the students. The second theme dealt with thoughts on their fellow students in the program. Because of the varied experiences, diverse cultural background, and knowledge that each student brought into the program participants felt they were able to learn from each other. The third area of strength of the MIDA program 
was its practical relevance to the international development work they were involved in. One alumni put it this way "we learned, (and) then we practiced what we learned." The fourth sphere dealt with the learning dimension of the program. The alumni thought the courses were well organized and delivered in a well-managed way. There was interactive dialogue between themselves and the professors. The felt they learned from each other. The last area that the alumni felt strong about was the opportunity to be involved in a graduate program that met their needs as working adults without a break in their employment situation.

The comments about improvements in MIDA program were a bit difficult to categorize. There were five main themes in this area. Course work and related topics was the first sphere of concern. There were several statements about the usefulness of the course in statistics. Some of the respondents felt it needed to be more practical. The second topic was about the professors themselves. Some of the alumni felt that some of the professors were academicians not practitioners in the field of international development. A third area was in the academic improvement. The total time in the program needs to be shortened from five years to three or four years by offering classes two times a year instead of once a year. The Department of International Development should offer a $\mathrm{PhD}$ program in international development. The fourth theme dealt with Andrews University. An off-campus MIDA site needs to be created in the Caribbean/ South American countries. The delivery of final grades for a course needs to be handled more quickly. The fifth area of improvement from the alumni perspective dealt with comments about their fellow students. Some of the alumni thought the motive in taking the MIDA program for some of the fellow students was to obtain higher paying jobs in 
non-faith-based employers. Several commented that students who are accepted into the program should have prior work experience in international development before applying into the program.

There were main six themes the alumni wrote about on the question about how the MIDA program can meet the present and future needs of the international development community. Some of the suggestions dealing with questions have been made in the previous discussions. The first theme dealt with program enhancement. Again there were several suggestions about getting a $\mathrm{PhD}$ program started. More emphasis on developing leadership skills was also put forth. A second theme talked about development issues. Among the ideas for consideration was to have a discussion about the political challenges that hamper development work. The third subject for improvement was learning dimensions. The professors needed to have current up-to-date information about all developing countries, not just for one region. Needed teaching staff from NGO's other than ADRA. The learning materials needed to be kept current. Other students had concerns about keeping up-to-date in the use of technology and its importance in development. Comments about their fellow students made up the fourth area for improvement. Some of the alumni felt that several of the students needed to have better quality communication skills, particularly in writing. The last area was named odds and ends. It has comments that were hard to place in a particular theme. The MIDA should offer refresher courses. Scholarships need to be made available so students can have less of a financial burden.

Research Question 10: What are the MIDA alumni thoughts and opinions of the off-campus Andrews University Master in International Development Administration of 
important courses or concepts that need to be included in the curriculum, or important concepts or principles that they learned from the program?

In the survey the alumni were asked two short answer open-ended questions about concepts or principles. One asked for them to identify three important concepts or principles they thought should be included in the program to improve it. The other question asked what were the three most important concepts or principles they learned from the program.

One of the areas where the MIDA program could be improved was in the subject of humanitarian issues. In this field there was discussion how peace education, conflict resolution, and the impact of terrorism on development needed to be added to the curriculum. Also alumni said more emphasis needed to be placed on human rights, particularly about violence against women, and a how to work for the intervention of children.

When it came to discussing what were the most important principles or concepts the alumni learned from the MIDA program there was a wide range of opinions on this topic. Organizational behavior garnered the most comments with most of them dealing with management or leadership skills. Anthropology was a course that they liked in the respect that it opened their eyes to how local or indigenous knowledge could be part of the development process. Proposal writing, needs assessment, monitoring and evaluation, and project management were important courses to the alumni in their learning to increase their own capacity building in international development. Finally some felt that the concept of reflection helped them shape their thinking. 


\section{Discussion}

This study specifically focused on alumni of the off-campus Master of International Development Administration of Andrews University. The intent was to gain from the alumni perspective their capacity building experience while in this graduate educational program and their perceptions of the transference of their learning to the international development work environment. The following section presents a discussion of the key findings of this study.

\section{Type of Organization}

One of the areas in this type of research was to gather and analyze demographic information from the random sample of the MIDA program alumni population who participated in the survey. This kind of analysis revealed that there was a change in the type of organization the alumni were employed by at the time they entered the program in contrast to the type of organization they were employed by at the time they participated in the survey. This was an unexpected finding, as nothing of this sort has been reported in the literature previously. Therefore no follow-up questions were included in the survey that would indicate why alumni may have changed employment organizations. One of the alumni in their response to one of the open-ended questions asked the question "How many ADRA participants went on to leave ADRA soon after receiving the (MIDA) degree for higher paying jobs with other organizations?" Granted there may have been some exiting of faith-based organization to obtain a higher paying position but there may be other considerations. The type of organizations that the alumni were employed by included: faith-based NGO's, private NGO's, governmental, and other (private business, 
foundations, and education).

While I was an academic advisor for the MIDA program several students individually confided in me that there were personal and professional political ramifications for them studying for a master's degree in international development. For many, they were now at a higher level of education than many of their directors or supervisors and because of this there was professional jealously within their office they had to deal with when they went back to work. That could be one reason why some felt they needed to go to another type of organization to get away from the intra-office politics.

There may be another aspect to reflect on. The question immediately following the type of organization they were employed by in the survey asked about their level of responsibility/job title before and after they obtained the MIDA degree. Both female and male (71\%) alumni said they had higher levels of responsibility or job title after they had obtained the graduate degree in international development. Consequently the alumni may have moved away from being employed by a faith-based organization to another type of organization to advance professionally. This is an area of future research on why alumni may choose to change to a different type of organization to be employed by.

\section{Alumni's Perceptions of Experiencing Individual Capacity Building}

An alumni perception of whether or not they experienced individual capacity building was the basis for second research question. Capacity building is synonymous to human development (Crocker \& Schwenke, 2005). Of the alumni, 87\% reported they experienced personal capacity building because of the education they received while 
being in the MIDA program. This would be consistent with Chin's (2008) findings that individuals who were engaged in capacity building educational programs improved at a personal level (Chin, 2008).

The alumni also felt that because of the international development program they are more adaptable and better able to contribute to the organizations they work for $(86.8 \%)$, generally enhance the quality $(86.8 \%)$ and dignity $(88.4 \%)$ of human development in society, and meet the changing needs within the international development community (89.9\%). These findings are consistent with those reported by other researchers, that these general areas represent the main outcomes of individual capacity building (Crocker \& Schwenke, 2005; de Crombrugghe, 2010; Horton, 1998).

\section{Alumni Perceptions of Course Delivery}

Course delivery is an assortment of different but interlocking items within the study that dealt with teaching, the learning environment, and fellow students. In the area of teaching, which included the professors, instructors, and concentration research mentors, the alumni perceptions were favorably impressed with the academic professionalism of all the persons who were involved with the MIDA program. The professors and instructors were rated overall from very good to excellent (92.7-94.3\%), while the concentration research mentors were rated as good (71-73.9\%).

The alumni thought because the professors and instructors were practitioners in the area they taught in it lent credence to what they presented. They liked the practical application of the MIDA program which they could immediately apply to their own work 
and professional careers. One alumnus stated "we learned, (and) then we practiced what we learned" and it was "so valuable to build my future." This is in harmony with what the World Bank (Chin, 2008) has found that for a successful program of individual capacity building learning to occur it needed to be of a practical nature.

The alumni really liked the aspect that the professors fostered in-class discussions between themselves and the students $(92.9 \%)$. Also the professors encouraged and guided dialogue between the students on the concepts and principles being taught in the class or from their assigned reading $(92.8 \%)$. For the most part the teaching faculty of the program made themselves available outside the normal class period to clarify or explain various aspect of the course to individuals or to small groups of students $(85.2 \%)$. The importance of this high level of open communication is consistent with Chin's findings (2008).

As part of the academic requirements of the MIDA program the students within the program has to complete an original research project in some facet of international development. To help the students through the research process a concentration research mentor, with expertise in the alumnus' field of study was assigned to guide in formulating the research problem, research questions and null hypotheses, methodology, literature review, findings, conclusions, and final written document of publishable professional quality.

The alumni perceptions of the concentration research mentor were positive in helping them through the research process. They felt that the mentors were instrumental in their success in the research process $(73.9 \%)$, and helpful in pointing them is the right 
direction as far as what resources to use in their project (71.0\%), (LaFond \& Brown, 2003).

There were several topics within the learning environment of course delivery. One of topics dealt with the course materials that were made available to the students throughout the MIDA program. The alumni felt that the course materials were useful in enabling the learning process $(92.9 \%)$, were academically challenging $(70.0 \%)$, and high quality (80.7\%). Chin (2008) found all these aspects of course delivery are consistent with having a quality program for the participants.

The alumni thought that the program strengthened their knowledge from their undergraduate degree, and reinforced the on-the-job training they had received from their employers. They also liked that some of the courses had pre-session assignments that helped them understand what the face-to-face class was going to be like. Because most of the courses were taught as intensive one or two week modules there were post-session assignments for most of the classes. Most of the post-session assignments were written reports of projects that were an integral part of their normal work in the application of the principles or concepts taught within the course (LaFond \& Brown, 2003).

In this type of program the students who were accepted into the MIDA program are represented by diverse undergraduate degrees, cultures, worldviews and philosophical outlooks, a range of ages (25-65), different types of organization (faith-based, private, governmental), different hierarchal levels within an organization (local field offices to international headquarter offices), and gender. In spite of these obvious differences or perhaps because of them students felt they learned from each other, and professional and personal friendships were formed. One of the alumni had this comment, "It brought 
together people from various backgrounds, with differing levels of experiences, and we learned from each other." With this diversity of the kind of students that are accepted into the MIDA program it is a strength that needs to be continued in their admission policy that leads to capacity building learning for all it participants.

One of the aspects the alumni brought out was that they needed exposure to lecturers from other NGO's not just ADRA. To take it a step further this could also mean that academically qualified presenters from other organizations such as philanthropic foundations, donor agencies, government, or even private business should be considered as part of the teaching faculty to give a more holistic depiction of international development, rather than just from a NGO's opinion.

Some of the alumni felt that the total length of the program could be shortened from five years to possibly three or four years by having more sessions per year. Others thought that scholarships needed to be made available to offset the tuition costs of the program. Because of its diversity the respondents to this study thought that their fellow students did not have the same levels of knowledge and experiences $(70.0 \%)$ in the area of international development. Add to this that the alumni felt that students who had no experience or real knowledge in international development should not be accepted into the program because they really do not bring anything substantial to the learning environment.

\section{Alumni Perceptions of Project Cycle Management}

The Master of International Development Administration built its curriculum around project cycle management (PCM) as its centrally organizing framework for capacity building (International Development Program, 2014). The PCM model functions 
as a project development and management benchmark for various practitioners in international development (EuroAID, 2004). The alumni perceived using of PCM as the central academic heart for the MIDA curriculum was a good tactic in building their own individual capacity on how to do and practice international development.

Even though PCM is the center of the MIDA curriculum for how to manage development projects the International Development Department should think about introducing the students to other management frameworks they may encounter or may be required to use in the international development community. Here are two examples of management frameworks that are commonly used. Logical framework approach (LFA) is a project design methodology that centers around four analytical elements: problem analysis, stakeholder analysis, analysis of objectives, and analysis of strategies. It has been widely used by multilateral donor organizations and several NGO's provide LFA training to ground-level field staff (Logical Framework Approach, 2015). The second example is Knowledge Management Program (KM). This is a program that was developed by USAID "to connect people to the processes and technology that will help them to work effectively with partners to accomplish USAID's mission" (United States Agency for International Development, 2014b, p. 1). Its framework has a continuous learning cycle of generate, capture, share, and apply to create, promote knowledge sharing, and resources.

\section{Alumni Perceptions of Andragogy}

The theory of andragogy, the way adults learn (Knowles, et al, 2005), is an essential facet to the instructional methodology of the MIDA program. The survey asked 
the alumni perceptions about the concepts and principles of andragogy. From the answers the alumni gave to the survey questions it showed that a high percentage of them (7893\%) approached their learning style as adult learners. The concepts and principles of andragogy as used in the MIDA program were in harmony with what Knowles proposed about the adult learner (2005).

\section{Alumni Perceptions of Transformative Learning Theory}

A general approach about learning is also part of the pedagogical practice of the MIDA program. This study used Peter Jarvis's (2006) theory of transformative learning as the basis for the questions in the survey questionnaire. Overall results of items from this section demonstrated a fit with Jarvis' transformational learning.

The item "learning process never affected my emotions" produced interesting results. A combined $40 \%$ of respondents indicated strongly agree/agree, a combined $42 \%$ selected disagree/strongly disagree, and $18 \%$ answered neither agree nor disagree. This data from the alumni would indicate that they have mixed thoughts about the idea of learning effecting their emotions.

A one-way ANOVA by age categories was completed on the ten items to ascertain if there was any statistical significance of the items. It was found that two of the 10 items were statistically significant at the $p<.05$ level: "learning involves the five senses" $(p<.032)$, and "feeling is part of the learning process" $(p<.042)$. A follow up multiple comparisons analysis of the 10 items was completed. It was found that for "learning involves the five senses" the 51-55 year old group had a higher level of significance $(p<.012)$ when compared with the $\leq 35$ age group. This could be interpreted 
to mean that the older age group thought that the five senses are an important part in the transformative learning process compared with the younger age grouping category thinking that the five senses did not have such an important impact. The multiple comparison analysis of the item "feeling is part of the learning process" indicated there was no significant difference by age categories.

The transformative learning theory put forth by Peter Jarvis (2006) seems to support findings in this section except in the area of "learning involves the five senses." Further study needs to be carried out to see if age-related differences exist in other populations for "learning involves the five senses" or if these findings were just an anomaly in this study.

\section{Alumni Perceptions of Transference of Learning}

One of the outcomes of a capacity building educational program is that the learning that has taken place will be transferred to the organizations the alumni work for and throughout the rest of the international community (Chin, 2008; Connolly \& Lukas, 2002; Crossley \& Holmes, 2001; de Crombrugghe, 2001). The theoretical framework for this dissertation makes the case that a graduate educational program in international development has individual capacity building affects upon the alumni of the program. In turn the alumni transfer their learning to the organization, and then from the organization to society down to the individual at the grassroots level.

Several items on the survey instrument asked the MIDA alumni if they thought they had transferred the capacity building education they received to their work and their employing agency. The alumni felt that they had grown professionally (92.8\%), had 
greater leadership ability (89.8\%), and could be influential in helping the organization in fulfilling its own mission $(86.8 \%)$ These finding would be consistent with what others have written (LaFond \& Brown, 2003; United Nations Development Program, 2010a) on the impact of a capacity building programs.

The survey item that received the lowest score for the transference of learning to the organization from the alumni was that the supervisor encouraged the alumni to use their learning from the MIDA program (58.9\%). Another question asked the alumni if their supervisor understood what was taught within the MIDA program (69.1\%). A third dealt with supervisor expectations of the alumnus (70.6\%) putting into practice the things they have learned from the MIDA program. Chin (2008) writes that if persons attending a capacity building program the management of the organizations needs to support those efforts so capacity building can occur within the organization.

Based on the alumni self-reported data, the Andrews University MIDA program seems to have far exceeded the typical $50 \%$-level of transference of learning to the employing international development agency documented by other capacity building programs (Chin, 2008). This is true even when including the items that received the lowest number of "Strongly Agree/Agree" responses.

For transference of learning of individual capacity building to the organization to be successful there needs to be organizational support from the beginning of the capacity building educational process (Chin, 2008). There needs to be open avenues of communication for all interested entities throughout the educational capacity building process and after the educational process is formally finished. The organizations expectations and institutional support for the person(s) involved in the capacity building 
program, and the learners putting into practice what they have learned with a reasonable amount of encouragement, freedom of movement and support from the organization by working through the supervisors, and working alongside fellow colleagues to build the capacity of the organization.

As part of the curriculum of the MIDA there needs to be a conscious effort by the teaching faculty to give the students suggestions on how and when the concepts and principles learned while in the program can be introduced into the organizations they are employed by. These ideas need to be discussed with the students in an open and frank approach about what can be done to bring their own experience of capacity building into the organization without being confrontational or threatening to the management they are working with.

For example, in the class on organizational behavior the students could write a paper about their organization. Its mission and goals, its priorities, type of clientele that the organization serves, the management style within the organization, the kinds of development projects it is involved, future plans, and where they see the organization heading for the next five years. Within the paper the students would also talk about the transference of their learning into the organization using the concepts and principles of international development, and how they can be integrated into their particular organization.

Inter-Correlations of the Dependent Variables

Up to this point the six dependent variables have been discussed as if they were separate non-interrelated units. But in reality there may be a casual inter-correlation of 
the variables (Meehl, 1990). The following discussion looks at the possible casual intercorrelations of the dependent variables in the transference of learning to the organization.

Two of the goals of this graduate educational program in international development are for the alumni to (1) experience individual capacity building, and (2) to transfer their learning to their employing organizations. The World Bank's (Chin, 2008) experience has revealed that the transference of individual capacity building learning to the organizations are successful only about half the time.

From this study a path analysis was conducted to see if there is causality or correlation between the six dependent variables. It was discovered that there are connecting links between the variables that leads to the alumni's perception of them transferring their learning to the organizations (see Figure 7).

Four of the six variables are considered exogenous: project cycle management, andragogy, transformative learning, and course delivery interact among themselves in varying degrees of correlation. Almost $70 \%$ of the endogenous variable "experiencing individual capacity building" is directly attributed to the exogenous variables. What about the endogenous variable transference of learning, what is the strength of the correlation, directly or indirectly, that exists between all the variables that affect transference of learning? It was found that $77 \%$ of transference of learning is the result of the other five variables, and about $23 \%$ are due to unexplained or unknown factors. Thus, this path analysis validates the veracity of the tested components of the study's theoretical framework. 


\section{Potential Lessons for Other AU Off-Campus Programs}

The following discussion is based upon my reflections on the alumni's openended responses regarding the MIDA program, my own experience in academic program development, and evaluation and management. I have been an observer of this offcampus graduate educational program and have been involved in one way or another from almost its beginning. I have seen it evolve from an idea as a human resource academic development program for ADRA in the mid 1990's to a capacity building program that now embraces learners from other NGO's, government, public, and private entities of the international development community.

The MIDA program could have faded away after meeting ADRA's initial capacity building objectives were met, except for the strong academic leadership and the foresight of the former Deans of Affiliations and Extensions, Dr. Merlene Ogden, and Graduate Studies, Dr. Lisa Beardsley. These leaders at Andrews University saw the importance of this international development program and the opportunity it afforded globally in making an impact in the area of human development.

Based on the specific lessons I have learned from the off-campus Master of International Development Administration program, I have identified general suggestions that might strengthen off-campus programs. The following ideas are presented to Andrews University administrators for the consideration in the administration of current and proposed off-campus programs. Those involved in off-campus programs possess the expertise to identify which of the following general suggestions would be appropriate for their specific program. 
- Successful off-campus academic programs must have strong leaders.

- Successful off-campus academic programs to remain meaningful through continued, thoughtful development over time. This ensures the program continues to meet the ever changing practical world of work.

- Successful off-campus academic programs must go through periodic evaluation and updating of its curriculum every five years to keep it current in meeting the changing wants and needs of the academic discipline it represents and reflects the real work environment.

- Successful off-campus academic programs, while perhaps similar in many ways to programs offered by other universities, need to make a contribution in the specific academic field.

- Successful off-campus academic programs must find or make its own niche in the academic field they represent. A specific niche empowers the program to develop a prominent and influential voice in its academic field, which helps it thrive and be viewed as credible.

- Successful off-campus academic programs are members of and accredited by appropriate professional accreditation entities.

- Successful off-campus academic programs maintain current teaching materials within each course (textbooks, syllabi, course modules, and handouts).

- Successful off-campus academic programs make use of the latest information technology within the classroom, and for communication between faculty and students.

- Successful off-campus academic programs maintain high standards in admission policies.

- Successful off-campus academic programs have the best and brightest teaching faculty who are considered academically sound in the material they teach, and a leader in their field through research and application.

- Successful off-campus academic programs have a diversity of faculty in terms of experience, academic training, race-ethnicity, and practical knowledge.

- Successful off-campus academic programs have experienced academic advisors to give guidance and encouragement to the students.

- Successful off-campus academic programs maintain open communication with students from the beginning of the application process to the end of their academic program.

- Successful off-campus academic programs have a diversity of students in the program in terms of race-ethnicity, work experience, professional background, education, gender, and age. 
- Successful off-campus academic programs take intentional action after graduation to show the alumni they are still an important part of the program and the educational institution from which they graduated.

- Successful off-campus academic programs obtain feedback from the alumni on a regular basis regarding perceptions of their learning while in the program and how the academic program could be improved.

\section{Recommendation for Practice}

Recommendation 1: Because this study covered only the alumni who took their coursework in English, I would suggest that a similar study be conducted in the other languages. Even though the curriculum is the same across all the languages the findings from this study can only be directly generalized to those alumni who took their classes in English. If a similar study was conducted in the other languages it would give a better understanding how the capacity building curriculum has affected the total MIDA alumni population. It would determine if there are any differences between the language groups or see if the study findings in other languages verify the results of the alumni who took there course work in English.

Recommendation 2: In this study it was discovered that over half of the alumni who worked for a faith-based organization at the beginning of their studies have changed to another type of organization at the time the survey was answered. I would recommend that a follow-up study be conducted with the alumni and find out why some changed employment from one type of organization to another type while others remained in the same type of organization. This could be accomplished by first surveying the alumni with a short questionnaire. Then, interviews with selected alumni by open-ended questions to 
help development an understanding why alumni may have changed to a different type of organization or stayed within a certain type of organization.

\section{Theory Development}

The academically qualified students who are accepted into the off-campus Master of International Development Administration are working adults with varied skills and professional work experiences to draw on when they come back to the classroom. As experienced adult practitioners in the international development community they already bring an on-the-job training (OJT) perspective to their work, which most undergraduate students who go straight into graduate work right after graduation may not have. The leadership of ADRA wanted an academic program that would be capacity building in its nature to bring a higher level of professionalism and efficacy into the organization at all levels, from the local field office in a country to the central office in the United States. To this end the theoretical framework for this evaluation study is based upon three complimentary life-span development theories (Lusthaus, Adrien, \& Perstinger, 1999; Santrock, 1992): capacity building (Horton, 1998) andragogy, the adult learner (Jarvis, 2006; Knowles et al., 2005), and the transformative learning process (Jarvis, 2006).

\section{Life-span Development}

Understanding human life-span development has been the work of many people.

For more than 100 years scientists, researchers and observers of human behavior have made strides in understanding the human species from a developmental point of view. These studies of human development, from prenatal to older adults, demonstrate that human beings are a complex interaction of the physical, cognitive, and social. Because of 
the complexity of the human species it is almost impossible to study them in their totality. For this reason many scientists, researchers, and behavioral scientists have chosen to specialize their study of human development to get a small glimpse on how they operate. For example, Sigmund Freud focused on psychoanalytic theories; Jean Piaget studied cognitive development from infancy through adolescence; B. F. Skinner, a behaviorist, examined the external workings (behavior) of human beings rather than the internal processes which cannot be directly observed; and Abraham Maslow established a hierarchy of human needs (Santrock, 1992).

\section{Capacity Building}

The first aspect of this theoretical framework is capacity building, a concept that is difficult to come to grips with. There seems to be no leading theorist in this area as there is in andragogy (Knowles et al., 2005) or the transformative learning processes (Jarvis, 2006).

A current issue in international development work is the very nature of capacity building. Capacity building has been and still continues to be a way of helping individuals, communities, and organizations develop expertise and skills to achieve some goal, (Sessions, 1993) to help organizations perform at higher levels of effectiveness and efficiency, and be more sustainable (United Nations Development Program, 1998).

The following propositions of capacity building will be explored:

Proposition 1: Capacity building occurs at three levels: individual, organization, and society.

Proposition 2: Organizational capacity development is dependent on the 
development of capacity within the individuals employed by the organization.

Proposition 3: Societal development can best be accomplished by organizations whose employees have developed a professional capacity to effect change.

\section{Capacity Building Theoretical Framework}

In the context of international development I have identified three main areas that inform the current study theoretically: (a) MIDA curriculum /MIDA alumni, (b) an international development organization, and (c) society. Together these three areas represent a holistic model of capacity building in international development and its cyclical impact over time. The first area of this theoretical framework forms the basis of this research. A study of capacity building and its long term effects on the international development organization and in society is far beyond the scope of this dissertation due to time and resource demands which would capture the impact on both the organization and society.

The primary focus of the theoretical framework for this dissertation, as illustrated in Figure 7, is to visually represent capacity building in international development at micro and macro levels of influence, and intervention. The micro level looks at each of the components parts of the theoretical framework in capacity building while the macro level provides an overall picture of how these constituent's parts could interact and their impact over time. As will be seen "capacity-building is a multi-directional, multidimensional process" (Eade, 1997, p. 22) and its influence is never neutral in the development process. Capacity building influences performance at all levels (LaFond \& Brown, 2003). 


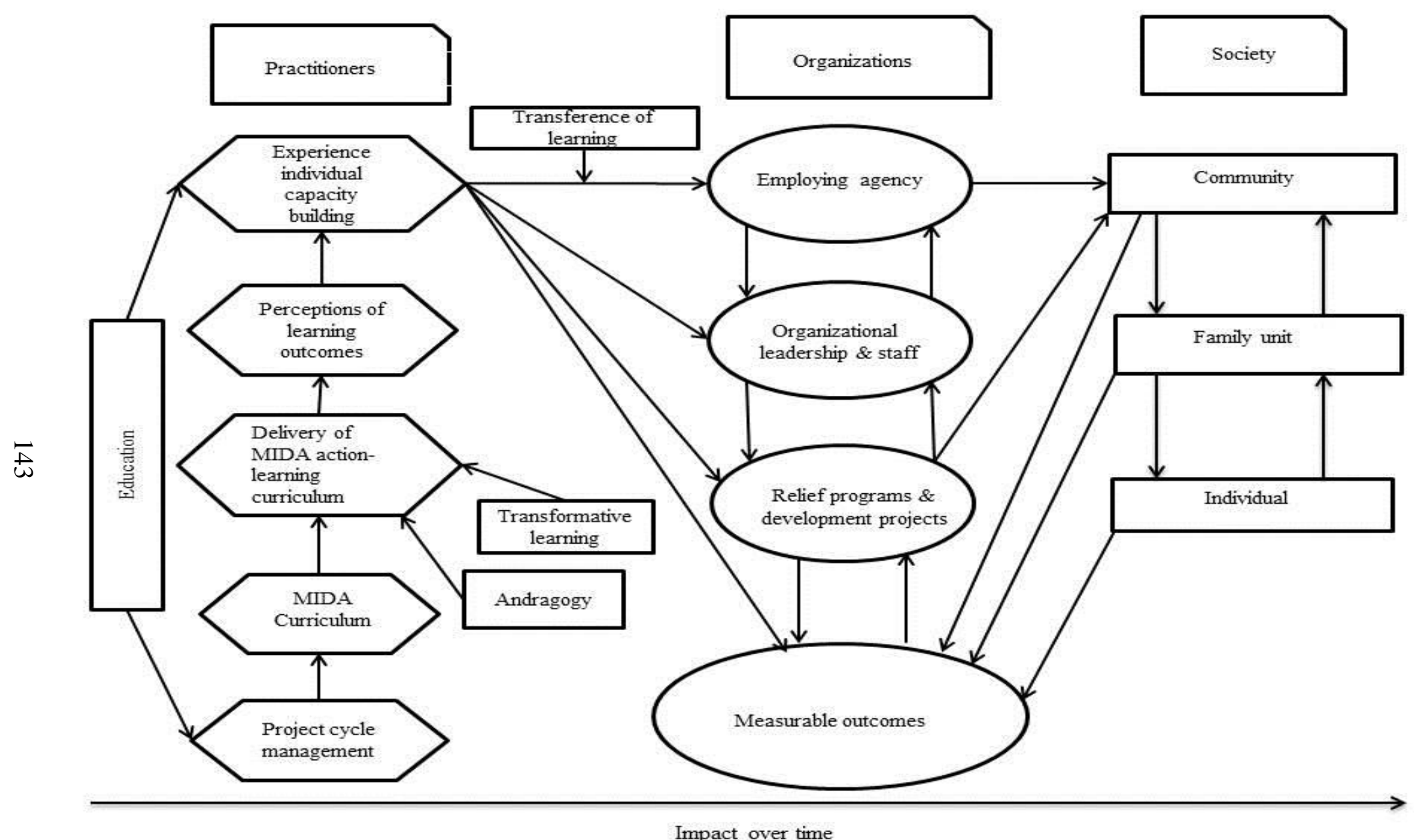

Figure 7. Theoretical framework for capacity building in international development. 
The chain of events as represented in this theoretical framework is based on the works of LaFond \& Brown (1997), United Nations Development Program (2010b), and Roberts \& Khattri (2012). This framework is a systematic cause-effect or results chain approach to capacity building in international development. The sequence of events within this theoretical framework is as follows: input, process, output, measureable outcomes, performance, and impact, (see Appendix A) catalogues each of the events, activities, and their associated variables.

The entry point for this theoretical framework was the development of a graduate curriculum with PCM as its core in the area of international development. Education is an important "investment in people ... to put a capacity-building approach to development into practice (Eade, 1997, p. 77). Curriculum is a set of organized courses within an academic discipline. The MIDA curriculum is the input portion of the theoretical framework. This curriculum includes coursework in social science, organizational management and accountability, grant writing, Christian social ethics, public policy, and research, terminating with a successfully written comprehensive examination (Andrews University, 2013)

The MIDA curriculum requirements are the process and output components of the theoretical framework. These requirements include the pre-session, in-class, and postsession assignments and projects the students need to meet for specific course objectives The measurable outcomes component are often "expressed as knowledge, skills and behavior" (LaFond \& Brown, 2003, p. 18). The list of measures (see Appendix A),

The measurable outcomes component are often "expressed as knowledge, skills, and behavior" (LaFond \& Brown, 2003, p. 18). The list of measures (see Appendix A), 
which are the focal points of this research, attempts to measure what knowledge, skills and behavior the MIDA alumni have carried over from the capacity building graduate curriculum in international development.

The performance component assesses the alumni's perception of their transference of learning to the organizations they are employed by. This component looks at the alumni's thoughts and feelings about their overall level of productivity and competence that contribute to the meeting the objective, goals or mission of the organization (LaFond \& Brown, 2003).

The last capacity building component is impact. Impact from a capacity building point of view is a long-term positive change in human development or people's wellbeing (United Nations Development Program, 2010a). As mentioned before capacity building is not neutral in its influence and if done properly it should be sustainable. Once a certain level of capacity has been achieved it becomes the new starting point for the next cycle of further capacity building (LaFond \& Brown, 2003), which reflects Jarvis's transformation learning theory illustrated in Figure 3. Therefore, capacity building as proposed in this dissertation is a transformative learning process that affects all levels within the international development community: individual practitioners in international development, organizations that employ them, and society.

\section{If-Then Logic Statement}

If the evaluation of the graduate off-campus international development program is based upon life-span development theories of (a) using capacity building as the vehicle for this adult educational development process (Horton, (1998), de Crombrugghe, 
(2010)), (b) andragogy (Knowles, et al., 2005), and (c) the transformative learning process (Jarvis, 2006), then it will be possible to determine if the alumni of this educational process have attained a higher level of professional capacity building that will benefit (a) the organizations they work for, and (b) the society they are trying to serve.

\section{Discussion}

The theoretical framework developed for this study can be looked upon as an original grounded theory proposal. Grounded theory is a general research method or tool "to seek out and conceptualise the latent social patterns and structures" (Scott, 2009, p. 1) in areas of interest through the construction of a theory through the analysis and comparison of data. It is not based upon intuition, hunches or a wishful assumption but is a process which involves critical thinking, and "simultaneous" (McCallin, 2015, p. 1) inductive and deductive reasoning.

The area of interest for this particular grounded theory, which had not previously been addressed in the literature, is the use of higher education as it correlates to international development capacity building, and its effect in three areas (1) international development practitioners, (2) international development organizations, and (3) society. This study tested one-third of the proposed theory, capacity building in international development practitioners, and made initial inquiry into impact on international development organizations.

Results from this study supported the positive effect a higher education graduate program in international development can have upon the capacity building of individual 
alumni. The following components of the educational program were statistically significant contributors to individual capacity building: project cycle management, experienced individual capacity building, andragogy, course delivery, and transference of learning.

Alumni perceived that in addition to learning and acquisition of knowledge in an international development educational program, they were able to transfer their learning to the organizations that employed them.

As this study focused on the practitioners of international development further empirical research needs to be conducted encompassing the possible inter-correlations of all the components of the proposed grounded theory: practitioners, organizations, and society. This kind of follow-up research would help close the gaps between the theory and actual practice. By doing so this grounded theory could be either verified or modified according to new relevant data as they are evaluated with existing information.

\section{Recommendations for Research}

Recommendation 1: Originally this research study had developed a survey that would have queried the leadership in the different organizations on their perceptions of the alumni's transference of learning to enhance the capacity building capabilities of the organization to meet its mission and goals (see Appendix B). Because of the low response rate from the organizations (5 usable responses) these data were not analyzed or reported for current study. I would recommend that an in-depth survey of the employing agencies be conducted to obtain data on the perceptions of the leaders of these organizations on the effectiveness of the MIDA alumni transference of learning to the 
organization, the alumni's effect upon the alumni's colleagues in the workplace, and the alumni's effect on the organization's capacity.

Recommendation 2: MIDA educational program in international development capacity building has a ripple effect throughout the international community. I would recommend that a longitudinal study of capacity building be conducted to ascertain its effects at different societal levels: the community, family, and the individual. My recommendation is to compare organizations that have MIDA alumni working within the organization with similar organizations that do not have MIDA alumni to see the effectiveness and long-term impact of the different development projects they are managing and/or have managed at the different levels of society.

Recommendation 3: One of the conclusions from the World Bank (Chin, 2008) study was that the capacity learning process for the international development practitioner needs to target the organization's needs. Therefore, I recommend that the International Development Program try to identify the most common organizational needs from the various organizations served by the MIDA program. To obtain each organization's needs the organizational survey mentioned in Recommendation 1 could be expanded to include items that speak directly to the perceived organizational needs. From the findings, these perceived needs could be integrated into the international development program. The content of courses could be differentiated by organizations represent by enrolled students and the regions where the program is offered. Once students preregister for a course, the professor could identify the employing organizations represented in the class and refine the course content based on the results of the organizational survey. It is likely that the perceived organizational needs could vary from region to 
region where the program is taught. For example, organizational needs in the African Region may be different than the needs in the Asian Region. So the teaching staff would need to keep those differences in mind when refining and differentiating their courses for presentation in the different regions.

Recommendation 4: Further study needs to be carried out on Peter Jarvis' theory of transformative learning to see if age-related differences exist in other populations for "learning involves the five senses."

\section{Limitations of the Study}

The survey questionnaire for this study on capacity building was developed by the writer of this document. Individuals who responded to the request to be part of this study did so on a voluntary basis and with complete anonymity. The main strength of this kind of self-reported method of data collection gives the respondents the freedom to describe their experience(s) without peer pressure or any other kind of observation. This very strength can also be seen as a weakness. Therefore the main limitation of this study is that the data is self-reported and it may be biased as far as the respondents providing socially

desirable answers, their introspective ability, and their understanding or interpretation of the questions being asked.

Another limitation is the survey questionnaire itself. Even though the survey questionnaire went through several stages of development and various individuals gave knowledgeable input into its development it has not been tested over a wide range of audiences in the area of international development. Therefore its needs to be further tested to ascertain its validity and reliability to measure capacity building in 
international development.

A third limitation is that program directors from other universities, NGO's, and private and government entities could use expert judgement to learn from the findings of this study.

\section{Conclusions}

According to the findings, the Andrews University off-campus MIDA program did an excellent job in helping alumni (1) experience individual capacity building, and (2) transfer their learning to their work place. The alumni thought that project cycle management was a good framework to bond all the core courses around. The concepts and principles of andragogy were supported. The theory of transformative learning was validated. An unexpected finding from this study was that over half of the alumni that worked in faith-based organizations at the beginning of the MIDA program moved on to other types of organizations after graduating from the program. The conceptual framework for this study was verified that the components (course delivery, andragogy, transformative learning, project cycle management, experiencing individual capacity building, and transference of learning) led to transference of learning to the work environment.

The diversity of the kind of students (work experience, professions represented, cultures, and ethnicity) who were accepted and graduated from the MIDA program added to the learning experience of all the participants. They developed personal and professional friendships that went beyond the classroom. The students expressed the thought that the faculty were knowledgeable about what they taught, professional, 
friendly, and were helpful inside and outside the classroom environment. 
APPENDICES 
APPENDIX A

CAPACITY BUILDING AND ITS VARIABLES 
Capacity Building and Its Variables

\begin{tabular}{|c|c|c|}
\hline & \multicolumn{2}{|r|}{ Variables } \\
\hline Input & $\begin{array}{l}\text { Graduate educational } \\
\text { curriculum in international } \\
\text { development }\end{array}$ & \\
\hline Process & $\begin{array}{l}\text { Activities or practices used } \\
\text { in pursuit of expected results }\end{array}$ & $\begin{array}{l}\text { Proposed in-class \& post- session } \\
\text { assignments }\end{array}$ \\
\hline \multirow[t]{2}{*}{ Output } & Set of activities & $\begin{array}{l}\text { In-class \& post-session } \\
\text { assignments }\end{array}$ \\
\hline & & Variables \\
\hline \multirow[t]{14}{*}{$\begin{array}{l}\text { Measurable } \\
\text { outcomes }\end{array}$} & & $\begin{array}{l}\text { Promote team-building within an } \\
\text { organization }\end{array}$ \\
\hline & & Higher potential leadership \\
\hline & & $\begin{array}{l}\text { Higher quality of overall work when } \\
\text { compared with non-MSA/MIDA } \\
\text { graduates }\end{array}$ \\
\hline & & $\begin{array}{l}\text { Help the employing organization fulfill } \\
\text { its mission }\end{array}$ \\
\hline & & $\begin{array}{l}\text { Better skill sets to complete assigned } \\
\text { tasks }\end{array}$ \\
\hline & & $\begin{array}{l}\text { Contribute to the capacity building } \\
\text { efficacy of the organization }\end{array}$ \\
\hline & & $\begin{array}{l}\text { Enhance the dignity of human } \\
\text { development in society }\end{array}$ \\
\hline & & Grown professionally \\
\hline & & $\begin{array}{l}\text { Skill to look at } \\
\text { International development issues more } \\
\text { critically }\end{array}$ \\
\hline & & $\begin{array}{l}\text { Produce better quality fundable project } \\
\text { proposals when compared with non- } \\
\text { MSA/MIDA graduates }\end{array}$ \\
\hline & & $\begin{array}{l}\text { Anticipate changing needs of } \\
\text { organization }\end{array}$ \\
\hline & & $\begin{array}{l}\text { Function as an international development } \\
\text { professional }\end{array}$ \\
\hline & & $\begin{array}{l}\text { Enhance the quality of human } \\
\text { development in society }\end{array}$ \\
\hline & & $\begin{array}{l}\text { Meet the changing needs within the } \\
\text { international development community }\end{array}$ \\
\hline Performance & $\begin{array}{l}\text { Assess short-term results as } \\
\text { they are manifested in the } \\
\text { organizations the } \\
\text { MSA/MIDA alumni are } \\
\text { employed }\end{array}$ & \\
\hline
\end{tabular}


Capacity Building and Its Variables - Continued

\begin{tabular}{|l|l|l|}
\hline Impact & $\begin{array}{l}\text { Long-term results through } \\
\text { improved performance of the } \\
\text { organization }\end{array}$ & \\
\hline Results & Goal & $\begin{array}{l}\text { Increase the overall capacity building } \\
\text { capabilities of the MSA/MIDA alumni, } \\
\text { organization, and society }\end{array}$ \\
\hline
\end{tabular}

Adapted from a table on page 20 of $A$ guide to monitoring and evaluation of capacity building in the health sector in developing countries, (2003). 
APPENDIX B

SURVEYS AND LETTERS 


\section{MIDA Alumni Survey}

\section{Language}

In what language was your international development program from Andrews University delivered?

¿En qué idioma fue su programa de desarrollo internacional de la Universidad Andrews entregado?

Dans quelle langue a été votre programme de développement international de l'Université Andrews livré?

На каком языке был вашей программы международного развития из университета Эндрюс доставлен?

$$
\begin{aligned}
& \text { English } \\
& \text { Español } \\
& \text { Français } \\
& \text { Русский }
\end{aligned}
$$

\section{Informed Consent Form}

Andrews University

Department of Teaching, Learning, and Curriculum

I (Ralph C. Wood) am conducting a research study as part of my doctoral studies in the School of Education at Andrews University, Berrien Springs, Michigan. Your participation in this study is greatly appreciated.

Research Title: Capacity Building for International Development Practitioners Through an off-Campus Educational Program.

Purpose of Study: The main thrust of this doctoral dissertation falls into four broad categories. First, the objective is to ascertain if alumni believe they have developed capacity to function more effectively and efficiently because of their participation in the Master of International Development Administration (MIDA) program. Second, the project intends to evaluate from the alumni's' perspective the academic strengths and challenges of the MIDA curriculum as it pertains to capacity building in the arena of international development. Third, the study will gather data from thought leaders in the organizations employing the alumni on how the MIDA program has helped the graduates' overall work and impact on the efficacy of the agency in meeting their own development goals. Fourth, the study seeks to parse out what lessons can be learned from this form of off-campus education and how Andrews University can apply these lessons to other off-campus graduate programs.

Duration of participation in study: I understand that I am being asked to complete a survey which will take approximately 15-20 minutes of my time. 
Benefits: There will be no direct benefit to me as a participant in completing this survey.

Risks: There are no risks to me as a participant in completing this survey.

Voluntary Participation: I have been informed that my participation in this study is completely voluntary. I am aware that there will be no penalty or loss of benefits I'm entitled to if I decide to cancel my participation in this study. There is no cost to me for participating in this study.

Confidentiality: I understand that my identity in this study will not be disclosed in any published document and that researcher will keep the records for a period of one (1) year in an electronic password protected lockbox that will be known only to the primary investigator. I also understand that the records will be deleted and destroyed at the end of the one (1) year period.

Contact: I am aware that I can contact the dissertation advisor of Ralph C. Wood, Dr. Larry Burton at burton@ andrews.edu, or Ralph C. Wood at rcwood90@ gmail.com for answers to questions related to this study.

I have read the contents of this Informed Consent Form and received email explanations to any initial questions I had. My questions concerning this study have been adequately answered.

Please select one of the options below to indicate your willingness to participate in this study.

I hereby give my voluntary consent to participate in this study.

I decline the invitation to participate in this study. (If you decline to participate in this survey you will not be able to take the survey at a later time.)

\section{Introduction: Seeking Truth}

This survey will be asking for your opinions, thoughts and feeling about different aspects of the off-campus graduate program in international development of Andrews University (MIDA).

Please answer all the questions honestly and to the best of your ability. On the average it will take approximately 15-20 minutes to complete this survey.

If for some reason you are not able to finish the survey once you have started you can return to the survey later and finish it. But do not wait too long to come back to it.

3. Gender:

Female

Male

4. Present age. 
5. What was your undergraduate (bachelor's degree/first degree) major?

6. Other than the MIDA, do you hold any other academic or professional degrees beyond?

the bachelor's level?

Yes

No

7. What year did you begin the MIDA program in international development?

8. What year did you attend your last onsite teaching session for the MIDA?

9. What year did you graduate from the MIDA?

10. How old were you when you graduated from the MIDA?

11. What type of organization did you work for when you began the MIDA?

Faith-based NGO (for example: ADRA, World Vision, etc.)

Government Organization (Ministry, USAID, etc.)

Private NGO (for example: CARE, Red Cross, etc.)

Other (Donor agency, foundation, education, unemployed, volunteer, etc.)

Other (please specify)

12. What type of organization do you work for now?

Faith-based NGO (for example: ADRA, World Vision, etc.)

Government Organization (Ministry, USAID, etc.)

Private NGO (for example: CARE, Red Cross, etc.)

Other (Donor agency, foundation, education, unemployed, volunteer, etc.)

Other (please specify)

13. At this moment what is your job title?

14. How do your present responsibilities and/or job title compare with your job when you entered the MIDA?

Now at a higher level

Still at about the same level

Now at a lower level 


\section{MIDA Application Process}

15. For you, how was the application process for getting accepted into the MIDA program?

No problems

Some minor problems

At least one major problem

Complicated

Slow

16. How would you judge the communication level between the MIDA Office and you during the application/acceptance process?
Poor
Fair
Good
Very good
Excellent

\section{The Classroom, Course Materials, Instructor and You}

17. What would you consider the ideal number of students per class in order to provide the best learning experience?

18. What was the average number of students in most of the classes you took?

19. Course materials, when provided, were useful in facilitating my learning the course.

Strongly agree

Agree

Neither agree nor disagree

Disagree

Strongly disagree

20. Course instructors referred to or used these course materials while teaching the course.

Not at all

Not very often

Often

Quite often

Very often

21. The course materials were of high quality.

Strongly agree 
Agree

Neither agree nor disagree

Disagree

Strongly disagree

22. The course materials were academically challenging.

Strongly agree

Agree

Neither agree nor disagree

Disagree

Strongly disagree

23. Pre-session assignments, when given, were useful in helping me understand what the face-to-face course was going to be about.

Strongly agree

Agree

Neither agree nor disagree

Disagree

Strongly disagree

24. Post-session assignments or projects, when given, helped me reinforce the principles or concepts of the courses.

Strongly agree

Agree

Neither agree nor disagree

Disagree

Strongly disagree

25. The courses covered the right amount of topics for the amount of time allotted.

Strongly agree

Agree

Neither agree nor disagree

Disagree

Strongly disagree

26. The students in the program had equal levels of knowledge in the area of international development coming into the program.

Strongly agree

Agree

Neither agree nor disagree

Disagree 
Strongly disagree

27. The students in the program had about equal levels of experience in international development coming into the program.

Strongly agree

Agree

Neither agree nor disagree

Disagree

Strongly disagree

28. I learned from the professional experiences of other students that were in the program.

Strongly agree

Agree

Neither agree nor disagree

Disagree

Strongly disagree

29. The instructors were knowledgeable about what they taught.

Strongly agree

Agree

Neither agree nor disagree

Disagree

Strongly disagree

30. The instructors fostered in-class discussions between themselves and the students.

Strongly agree

Agree

Neither agree nor disagree

Disagree

Strongly disagree

31. The instructors fostered in-class discussions between students about the principles and/or concepts being taught during the course.

Strongly agree

Agree

Neither agree nor disagree

Disagree

Strongly disagree 
32. The instructors were available for after-class discussions with students to explain or clarify concepts or class requirements.

Strongly agree

Agree

Neither agree nor disagree

Disagree

Strongly disagree

33. The MIDA program strengthened knowledge from my undergraduate degree.

Strongly agree

Agree

Neither agree nor disagree

Disagree

Strongly disagree

34. The MIDA program has reinforced my previous on-the-job learning experiences.

Strongly agree

Agree

Neither agree nor disagree

Disagree

Strongly disagree

\section{My Concentration Mentor and the Research Process}

35. My concentration research mentor was instrumental to my success in the research process.

Strongly agree

Agree

Neither agree nor disagree

Disagree

Strongly disagree

36. My concentration research mentor helped me in my research project.

Strongly agree

Agree

Neither agree nor disagree

Disagree

Strongly disagree 
37. My concentration research mentor pointed me to resources that could be helpful in my research project.

Strongly agree

Agree

Neither agree nor disagree

Disagree

Strongly disagree

38. The Andrews University Institutional Board Review (IRB) process for getting permission to do your research was easy to complete.

Strongly agree

Agree

Neither agree nor disagree

Disagree

Strongly disagree

39. Who was the most helpful to you in completing the IRB process?

Concentration research mentor

Part of the research methodology class

Director of the program

Other

Other (please specify)

\section{My Thoughts on the MIDA Program}

40. Because I completed the MIDA ...

Strongly agree Agree Neither agree nor disagree Disagree Strongly disagree

I have grown professionally.

I have the skills to look at development issues more critically.

I am better able to work as a team member for my employing organization.

I am better able to produce practical, fundable project grant proposals than before the program.

I am more adaptable to the changing needs of my organization.

I am more influential in helping the organization I am employed by in fulfilling its mission.

I am able to produce higher quality professional work.

I have greater leadership potential.

I am better equipped at completing an assigned task.

41. If asked by someone about a graduate program in international development, would you recommend the MIDA of Andrews University? 
Not recommend

Unlikely to recommend

Neutral

Likely to recommend

Recommend highly

\section{Individual Capacity Building}

For this study I am using the following definition for capacity building: Individual capacity building is the process of developing new skills and critical thinking practices to augment and build on prior learning and professional life experiences. Individual capacity building has the power to improve the work and efficacy of organizations, thus enhancing the dignity and quality of human development, which affect all levels of society.

Answer each of the following questions in the context of this definition.

42. The MIDA Program ...

Strongly agree Agree Neither agree nor disagree Disagree Strongly disagree

Instilled in me capacity building principles and concepts.

Helped me develop individual capacity to function as an international development professional.

Helped me contribute to the capacity building efficacy of my employing organization.

Prepared me to enhance the quality of human development in society. Prepared me to enhance the dignity of human development in society. Prepared me to meet the changing needs within the international development community.

Helped me broaden my professional networking with other organizations or within my own organization.

\section{Core Courses and Project Cycle Management (PCM)}

Within the international development curriculum twenty-six semester credit make up the core courses that all the students have to take. These core courses are built around the 6 phases of project cycle management (PCM): (programming, identification, formulation, financing, implementation, and evaluation) Each of the core courses is linked with a particular phase of PCM.

Please answer the following questions about the core courses and PCM.

43. Using the core courses and PCM together was ...

Strongly agree Agree Neither agree nor disagree Disagree Strongly disagree 
A good academic method to teach about international development. A good framework to learn about the interconnected phases of project development.

A good model for learning how to write project proposals.

A good approach to learn team building.

A good approach to learn how to implement development projects.

A good approach for learning how to understand the financial side of a development project.

A good approach for learning how to evaluate a development project.

44. PCM is a good model...

Which the organization could use in its own development mission.

For individual capacity building.

For organizational capacity building.

To follow for managing development projects.

To do development.

45. The PCM model is used in your organization to design and manage development projects.

Yes

We use another approach (please specify):

\section{Being an Adult Learner}

46. During my experience within the MIDA program, ...

Strongly agree Agree Neither agree nor disagree Disagree Strongly disagree

The professors helped me understand WHY the content of their courses was important.

The professors allowed me to be more self-directed as a learner when appropriate. The professors allowed me to be more independent as a learner when appropriate. The professors expected me to draw from my experiences to advance my learning in their classes.

The professors planned activities requiring me to connect previous experiences to new learning in their classes.

My classes engaged me because they were related to real-life international development situations.

I was able to apply new concepts and ideas about international development immediately.

My classes focused on solving real-life practical problems rather than memorizing international development course content.

My motivation to learn came more from within myself than from my professors. 
I enthusiastically continued my professional development in international development.

\section{Learning and Me}

As a MIDA alumnus you have gone through a graduate level educational experience that had a planned curriculum in the arena of international development. You were introduced to new concepts and ideas which challenged you to learn, expanded your level of knowledge, and asked you to put this new knowledge into practical application.

47. The next few questions will ask about this learning process while you were in the MIDA program and how it may have affected you.

Strongly agree Agree Neither agree nor disagree Disagree Strongly disagree

The learning process involved one or more of the five senses (taste, sight, touch, hearing, and smell).

Reflection was part of the learning process.

I was able to take learning moments and transform and internalize them into a new "mental meaning."

The learning process never affected my emotions.

My learning was enhanced through thinking.

My learning was enhanced through feelings.

My learning was enhanced by taking action.

New learning was always connected to my previous knowledge.

New learning had a transformative effect on me.

Has improved my problem solving skills.

\section{Organizational Impact}

48. My immediate supervisor has an understanding of what I was taught.

Strongly agree

Agree

Neither agree nor disagree

Disagree

Strongly disagree

49. The principles and concepts taught in the MIDA program are ones I use on the job.

Strongly agree

Agree

Neither agree nor disagree

Disagree

Strongly disagree 
50. My immediate supervisor encourages me to use what I have learned from the MIDA program.

Strongly agree

Agree

Neither agree nor disagree

Disagree

Strongly disagree

51. My immediate supervisor expects me to put into practice the things I have learned from the MIDA.

Strongly agree

Agree

Neither agree nor disagree

Disagree

Strongly disagree

\section{Organizational Information}

52. Please provide the name of the organization you are employed by, the name of your immediate supervisor, and his/her email address. The purpose for this information is to possibly send that person a survey to get their opinions, thoughts, and feelings of different aspects of the MIDA, and its impact upon your organization. No personal information will be sought about you.

1. Name of organization

2. Name of immediate supervisor

3. Email address of immediate supervisor

\section{Personal and Professional Reflections}

53. How did you learn about the MIDA?

Colleagues that have attended the program

From my supervisor or boss

Internet

Other

Other (please specify)

54. The work in the international development community is dynamic and ever changing. In your opinion what three (3) courses or concepts need to be included in the curriculum of the MIDA to improve it and/or keep it relevant?

1.

2. 
3.

55. In your opinion what were the three (3) most important concepts or principles that you learned from the MIDA?

1.

2.

3.

The following three (3) open-ended questions give you the opportunity to express in your own words your deepest personal and professional reflections about the off-campus graduate program in international development of Andrews University. Your thoughts, opinions, and feelings mean a lot to me as the primary investigator/researcher for this investigation. I will be the only person who will see your actual written statements and they will be held in the strictest confidence. At no time will your statements be associated with you if they are used as a quote in the body of the finished dissertation.

Your answer(s) are to be typed into the scrolling answer box. As you type in your answer(s) and the answer box fills it will scroll up and some of the first lines typed will scroll off the screen. Do not worry they are not lost. If after typing your response and you want to read what has scrolled off the screen use the arrows on the right side of the answer box to scroll up or down. Also you can retype or make additions to your response just like you would do with any other word processing program.

Please be honest and truthful with your answers. These questions do not restrict you from talking about other subject(s) that you think are important to discuss as long as they pertain to the international development program or Andrews University.

56. As you look back on your educational experience with the off-campus graduate program in international development offered by Andrews University, what would you say were the strengths of the program?

57. As you look back on your educational experience with the off-campus graduate program in international development offered by Andrews University, what would be your recommendations on how the program could be improved?

58. As you look back on your educational experience with the off-campus graduate program in international development offered by Andrews University, how could the program be strengthened to meet the present and future needs of the international community?

\section{Submitting the Survey}

Thank you for your time in answering this survey questionnaire!!

Please go back over the survey questionnaire and make sure you have answered all the questions. 
If you are satisfied that you have answered all the questions push the "Done" button.

Once the "Done" button is pushed you will not be able to return to the survey questionnaire to change your answers.

Are you sure that you are ready to push the "Done" button??

\section{AGAIN, THANK YOU FOR YOUR SUPPORT!}




\section{Organizational Survey}

\section{Andrews University}

Department of Teaching, Learning, and Curriculum

I (Ralph C. Wood) am conducting a research study as part of my doctoral studies in the School of Education at Andrews University, Berrien Springs, Michigan. Your participation in this study is greatly appreciated.

Research Title: Capacity Building for International Development Practitioners through an Off-Campus Educational Program.

Purpose of Study: The main thrust of this doctoral dissertation falls into four broad categories. First, the objective is to ascertain if alumni believe they have developed capacity to function more effectively and efficiently because of their participation in the Master of International Development Administration (MIDA) program. Second, the project intends to evaluate from the alumni's' perspective the academic strengths and challenges of the MIDA curriculum as it pertains to capacity building in the arena of international development. Third, the study will gather data from thought leaders in the organizations employing the alumni on how the MIDA program has helped the graduates' overall work and impact on the efficacy of the agency in meeting their own development goals. Fourth, the study seeks to parse out what lessons can be learned from this form of off-campus education and how Andrews University can apply these lessons to other off-campus graduate programs.

Duration of participation in study: I understand that I am being asked to complete a survey which will take approximately 15-20 minutes of my time.

Benefits: There will be no direct benefit to me as a participant in completing this survey.

Risks: There are no risks to me as a participant in completing this survey.

Voluntary Participation: I have been informed that my participation in this study is completely voluntary. I am aware that there will be no penalty or loss of benefits I'm entitled to if I decide to cancel my participation in this study. There is no cost to me for participating in this study.

Confidentiality: I understand that my identity in this study will not be disclosed in any published document and that researcher will keep the records for a period of one (1) year in an electronic password protected lockbox that will be known only to the primary investigator. I also understand that the records will be deleted and destroyed at the end of the one (1) year period. 
Contact: I am aware that I can contact the dissertation advisor of Ralph C. Wood, Dr. Larry Burton at burton@andrews.edu, or Ralph C.Wood at rcwood90@ gmail.com for answers to questions related to this study.

I have read the contents of this Informed Consent Form and received email explanations to any initial questions I had. My questions concerning this study have been adequately answered.

1. Please select one of the options below to indicate your willingness to participate in this study.

I hereby give my voluntary consent to participate in this study.

I decline the invitation to participate in this study (If you decline to participate in this survey you will not be able to take the survey at a later time.).

\section{Introduction: Seeking Truth}

This survey will be asking for your opinions, thoughts and feelings about different aspects of the off-campus Master of International Development Administration (MIDA) program in international development of Andrews University.

Please answer all the questions honestly and to the best of your ability. On the average it will take approximately 15-20 minutes to complete this survey.

If for some reason you are not able to finish the survey once you have started you can return to the survey later and finish it. But do not wait too long to come back to it.

\section{Tell Me About Yourself and Your Organization}

2. Gender

Female

Male

\section{Present age}

4. Are you an alumnus of the International Development Program of Andrews University?

Yes

No

5 . What is the name of your organization?

6. In what country is your office located 
7. What is the leadership title you hold within your organization?

8. What is the level of your leadership position?

\author{
Supervisor \\ Project manager \\ Middle management \\ Head of office \\ Chief executive officer (CEO) \\ Other
}

Other (please specify)

9. How long have you held this position?

Less than a year

One year

Two years

Three years

More than three years

10. What type of organization is this?

Faith-based NGO (for example: ADRA, World Vision, etc.)

Private NGO (for example: CARE, Red Cross, etc.)

Governmental Organization (for example: Ministerial, state, etc.).

Other, for example: [(Donor agency (USAID, SIDA, etc.) educational, medical etc.)] Please specify which.

Other (please specify)

11. What is the organizational level of the office you work in?

Local NGO, no other organizational entity

Country office of an international NGO (i.e. Red Cross, ADRA, CARE, etc.)

Administrative regional NGO, covers several surrounding bordering countries

(i.e. Division, Union, cooperative, etc.)

Headquarters office of an international NGO

Governmental Organization (Ministerial, state, etc.)

Other [(Donor agency, i.e. USAID, SIDA) educational, medical, etc.)]

Other (please specify

\title{
The MIDA Alumni That Work Within Your Organization
}

12. Are any alumni from the Andrews University Master of International Development Administration (MIDA) working within your organization? 
Yes

No

If you marked "yes" please continue with the survey. If "No" you do not need to complete the rest of the survey. Thank you for your time.

13. How many Andrews University MIDA alumni work within your office?

14. What position(s) do they hold? Please provide position(s) only, do not give names of the individuals in those positions.

15. The employee(s) of my organization who have a MIDA in international development

Strongly agree Agree Neither agree nor disagree Disagree Strongly disagree

Are more professional than those who have not earned the MIDA.

Have the skills to look at development issues more critically than those who have not earned the MIDA.

Are more influential in helping my organization meet its mission than those who have not earned the MIDA.

Produce higher quality work overall than those who have not earned the MIDA.

Are better able to work as in teams than those who have not earned the MIDA.

Have greater leadership potential than those who have not earned the MIDA.

Are better able to produce practical, fundable project grant proposals than those

who have not earned the MIDA.

Are better able at completing an assigned task than those who have not earned the MIDA.

Are more adaptable to the changing needs of my organization than those who have not earned the MIDA.

Are better informed of changes in the international development community than those who have not earned the MIDA.

\section{MIDA and Capacity Building}

For this study I am using the following definition for capacity building: Individual capacity building is the process of developing new skills and critical thinking practices to augment and build on prior learning and professional life experiences. Individual capacity building has the power to improve the work and efficacy of organizations, thus enhancing the dignity and quality of human development, which affect all levels of society.

Answer the following questions in the context of this definition.

16. The MIDA International Development Program

Strongly agree Agree Neither agree nor disagree Disagree Strongly disagree Instilled capacity building principles and concepts in its alumni. 
Helped its alumni develop individual capacity to function as an international development professional.

Helped the alumni contribute to the capacity building efficacy of this organization.

Prepared its alumni to enhance the quality of human development in society. Prepared its alumni to enhance the dignity of human development in society. Prepared its alumni to the meet the changing needs within the international development community.

\section{Core Courses and Project Cycle Management}

Within the international development curriculum twenty-six semester credit make up the core courses that all the students have to take. These core courses are built around the 6 phases of project cycle management (PCM): (programming, identification, formulation, financing, implementation, and evaluation). Each of the core courses is linked with a particular phase of PCM.

Please answer the following questions about the core courses and PCM.

17. Using the core courses and PCM together was

Strongly agree Agree Neither agree nor disagree Disagree Strongly disagree

A good academic method to teach about international development. A good framework to learn about the interconnected phases of project development.

A good model for learning how to write project proposals.

A good approach to learn team building.

A good approach to learn how to implement development projects.

A good approach for learning how to understand the financial side of a development project.

A good approach for learning how to evaluate a development project.

18. PCM is a good model

Strongly agree Agree Neither agree nor disagree Disagree Strongly disagree

Which the organization could use in its own development mission.

For individual capacity building.

For organizational capacity building.

To follow for managing development projects.

To do development

19. The PCM model is used in your organization to design and manage development projects. 


\begin{abstract}
Yes
We use another approach (please specify):

MIDA Recommendation
\end{abstract}

20. I would recommend an employee within my organization to apply for the MIDA of Andrews University.

Strongly agree

Agree

Neither agree nor disagree

Disagree

Strongly disagree

21. I have encouraged an employee within my organization to apply for the MIDA of Andrews University?

Yes

No

\title{
Personal and Professional Reflections on the MIDA Program
}

The following three (3) open-ended questions give you the opportunity to express in your own words your deepest personal and professional reflections about the off-campus graduate program in international development of Andrews University. Your thoughts, opinions, and feelings mean a lot to me as the primary investigator/researcher for this study. I will be the only person who will see your actual written statements and they will be held in the strictest confidence. At no time will your statements be associated with you or your organization if they are used as a quote in the body of the finished dissertation.

Your answer(s) are to be typed into the scrolling answer box. As you type in your answer(s) and the answer box fills the first few lines will scroll up and disappear off the screen. Do not worry they are not lost. If after typing your response and you want to read what has scrolled off the screen use the up and down arrows on the right side of the answer box to scroll up or down. Also you can retype or make additions to your response just like you would do with any other word processing program.

Please be honest and truthful with your answers. These questions do not restrict you from writing about other subject(s) that you think are important as long as they pertain to the MIDA program or Andrews University.

22. As a thought leader in your organization, what would you say are the strengths of the MIDA of Andrews University?

23. As a thought leader in your organization, what would be your recommendations on how the MIDA of Andrews University could be improved? 
24. As a thought leader in your organization, how could the MIDA of Andrews University be strengthened to meet the present and future needs of the international development?

\section{Submitting the Survey}

Thank you for your time in answering this survey questionnaire!!

Please go back over the survey questionnaire and make sure you have answered all the questionnaire.

If you have answered all the questions push the "Done" button.

Once the "Done" button is pushed you will not be able to return to the survey questionnaire to change any of your answers.

Are you sure that you are ready to push the "Done" button??

\section{AGAIN, THANK FOR YOUR SUPPORT}




\section{Pilot Alumni Survey Cover Letter \\ Andrews University}

(Date)

Dear CIDP Alumni:

I am Ralph Wood, a Doctoral of Philosophy candidate in the Department of Teaching Learning and Curriculum in the School of Education at Andrews University. As part of my doctoral work I am conducting a research study entitled: Capacity Building for International Development Practitioners Through an Off-Campus Graduate Educational Program.

I have developed a survey questionnaire to collect data from the alumni of the Off-Campus International Development Program of Andrews University on their thoughts, opinions, and feelings about their educational experience. Because this survey questionnaire has been self-developed I am taking several steps to ensure the validity of the questionnaire. An important part of this process is to field test the survey with a group comparable with the study population. The chief purpose for this pretesting process is to work out any possible problems in the survey instrument itself.

Because you are an alumnus of the on-campus program in community international development program (CIDP) of Andrews University your name has been recommended by Dr. Joel Raveloharimisy, the Director of the CIDP, to participate in the pretesting of the off-campus Master of International Development (MIDA) Alumni Survey instrument. I am asking you to complete and critique the survey, keeping in mind the following questions:

1) Is the questionnaire easy to navigate?

2) Is the meaning of any question unclear to you?

3) Are the response options appropriate for each question?

4) Do you have any suggestions for any additional questions that should be included in the questionnaire?

5) Is the layout of the survey instrument logical?

6) Are the instructions for filling out the questionnaire clear?

7) In your opinion was the survey questionnaire too long, too short or just about right?

8) Any written comments about the survey please type in the last question response box.

Please go to the following website to complete and critique the MSA Alumni Survey: http://www.surveymonkey.com/s/7WNLH7P. Any criticisms or comments you make about the survey questionnaire will be treated with the greatest professional confidence and reported anonymously.

Thank you in advance for helping me out and being part of this important research study.

Ralph C. Wood, BS \& MPH

$\mathrm{PhD}$ Candidate 


\section{Pilot Organizational Survey Cover Letter}

\section{Andrews 1 University}

(Date)

Dear NAME:

I am Ralph Wood, a Doctor of Philosophy candidate in the Department of Teaching, Learning, and Curriculum in the School of Education at Andrews University. As part of my doctoral work I am conducting a research study entitled: Capacity Building for International Development Practitioners through an Off-Campus Graduate Educational Program.

As a thought leader in your organization your name was recommended to take part in a survey about certain aspects of the off-campus Master of Science of Administration with an emphasis in International Development (MSA/MIDA) of Andrews University, which one or more of your employees are alumni. Cumulatively these organizational surveys will help me to try and understand the strengths and challenges of this program.

The survey will take approximately 15-20 minutes to complete. The answers you will be giving will be treated with the strictest confidence and anonymity. No person, outside of the primary investigator, will know how you answered the survey questionnaire. Your finished survey will be held secure in a password protected electronic file available only to me and my research advisors. Any direct quotes I use from the open-ended survey responses will be reported anonymously using pseudonyms instead of your actual name. After all the surveys have all been collected, data entered, and tabulated into a statistical computer program for analysis, the surveys will then be destroyed one year after the conclusion of the study.

Thank you in advance for your cooperation in this research endeavor. The conclusions and recommendations reached from this research will help in building a stronger, more viable educational program in international development to serve and meet the needs of the international development community.

Please go to the following website to begin answering the survey:

http://www.surveymonkey.com/s/JYNP95Z. Every completed survey counts. Let your voice be heard.

Sincerely

Ralph C. Wood, BS \& MPH

PhD Candidate 


\section{MIDA Alumni Survey Cover Letter}

\section{Andrews University}

(Date)

Dear NAME:

I am Ralph Wood, a Doctor of Philosophy candidate in the Department of Teaching Learning and Curriculum in the School of Education at Andrews University. As part of my doctoral work I am conducting a research study entitled: Capacity Building for International Development Practitioners through an Off-Campus Graduate Educational Program.

As alumni of Andrews University and its off-campus international development program (MSA/MIDA) I am asking you to take part in a survey about different aspects of the program you completed. I would appreciate your honest opinions, thoughts and feelings about your educational experience. Cumulatively these surveys will help me to try and understand the strengths and challenges of the program from the perspective of the students who experienced the program firsthand.

The survey will take approximately 15-20 minutes to complete. The answers you will be giving will be treated with the strictest confidence and anonymity. No person, outside of the primary investigator, will know how you answered the survey questionnaire. Your finished survey will be held secure in a password protected electronic file available only to me and my research advisors. Any direct quotes I use from the open-ended survey responses will be reported anonymously using pseudonyms instead of your actual name. After all the surveys have been collected, the data entered, and tabulated into a statistical computer program for analysis, the surveys will then be destroyed one year after the conclusion of the study.

Thank you in advance for taking this survey. The conclusions and recommendations reached from this research will help in building a stronger, more viable educational program in international development to serve and meet the needs of the international development community

Please go to the following website to begin answering the survey: http://www.surveymonkey.com/s/7WNLH7P. Every survey counts. Let your voice be heard.

Sincerely

Ralph C. Wood, BS \& MPH

$\mathrm{PhD}$ Candidate

PS. If you know of any MSA/MIDA alumni who have changed their email address and/or place of employment have them get ahold of me at rcwood90@gmail.com so that they can be a part of this important survey. 
Organization Survey Cover Letter

\section{Andrews $\$$ University}

(Date)

Dear NAME:

I am Ralph Wood, a Doctor of Philosophy candidate in the Department of Teaching, Learning, and Curriculum in the School of Education at Andrews University. As part of my doctoral work I am conducting a research study entitled: Capacity Building for International Development Practitioners through an Off-Campus Graduate Educational Program.

As a thought leader in your organization your name was recommended to take part in a survey about certain aspects of the off-campus Master of Science of Administration with an emphasis in International Development (MSA/MIDA) of Andrews University, which one or more of your employees are alumni. Cumulatively these organizational surveys will help me to try and understand the strengths and challenges of this program.

The survey will take approxiamately 15-20 minutes to complete. The answers you will be giving will be treated with the strictest confidence and anonymity. No person, outside of the primary investigator, will know how you answered the survey questionnaire. Your finished survey will be held secure in a password protected electronic file available only to me and my research advisors. Any direct quotes I use from the open-ended survey responses will be reported anonymously using pseudonyms instead of your actual name. After all the surveys have all been collected, data entered, and tabulated into a statistical computer program for analysis, the surveys will then be destroyed one year after the conclusion of the study.

Thank you in advance for your cooperation in this research endeavor. The conclusions and recommendations reached from this research will help in building a stronger, more viable educational program in international development to serve and meet the needs of the international development community.

Please go to the following website to begin answering the survey:

http://www.surveymonkey.com/s/JYNP95Z. Every completed survey counts. Let your voice be heard.

Sincerely

Ralph C. Wood, BS \& MPH

PhD Candidate 
APPENDIX C

IRB APPROVAL LETTER 
July 7, 2014

\title{
Andrews University
}

Ralph Wood

Tel: (269) 921-0038

Email: rcwoodgo@gmail.com

\begin{abstract}
RE: APPLICATION FOR APPROVAL OF RESEARCH INVOLVING HUMAN SUBJECTS IRB Protocol \#:14-077 Application Type: Original Dept.: Teaching, Learning \& Curriculum Review Category: Exempt Action-Taken: Approved Advisor: Larry Burton

Title: Capacity Building for International Development Practitioners through an off-Campus Educationala Program.
\end{abstract}

Your IRB application for approval of research involving human subjẹcts entitled: "Capacity Building for International Development Practitioners and Off-Campus Educational Program" IRB protocol \# 14-077 has been evaluated and determined exempt from IRB review. You may now proceed with your research.

Please note that any future changes made to the study design and/or informed consent form require prior approval from the IRB before such changes can be implemented. Incase you need to make changes please use the attached report form.

While there appears to be no more than minimum risks with your study, should an incidence occur that results in a research-related adverse reaction and/or physical injury, this must be reported immediately in writing to the IRB. Any research-related physical injury must also be reported immediately to the University Physician, Dr. Reichert, by calling (269) 473-2222.

We ask that you reference the protocol number in any future correspondence regarding this study for easy retrieval of information.

Best wishes in your research.

Sincerely,

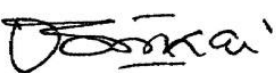

Mordekai Ongo

Research Integrity \& Compliance Officer 


\section{National Institutes of Health Certificate}

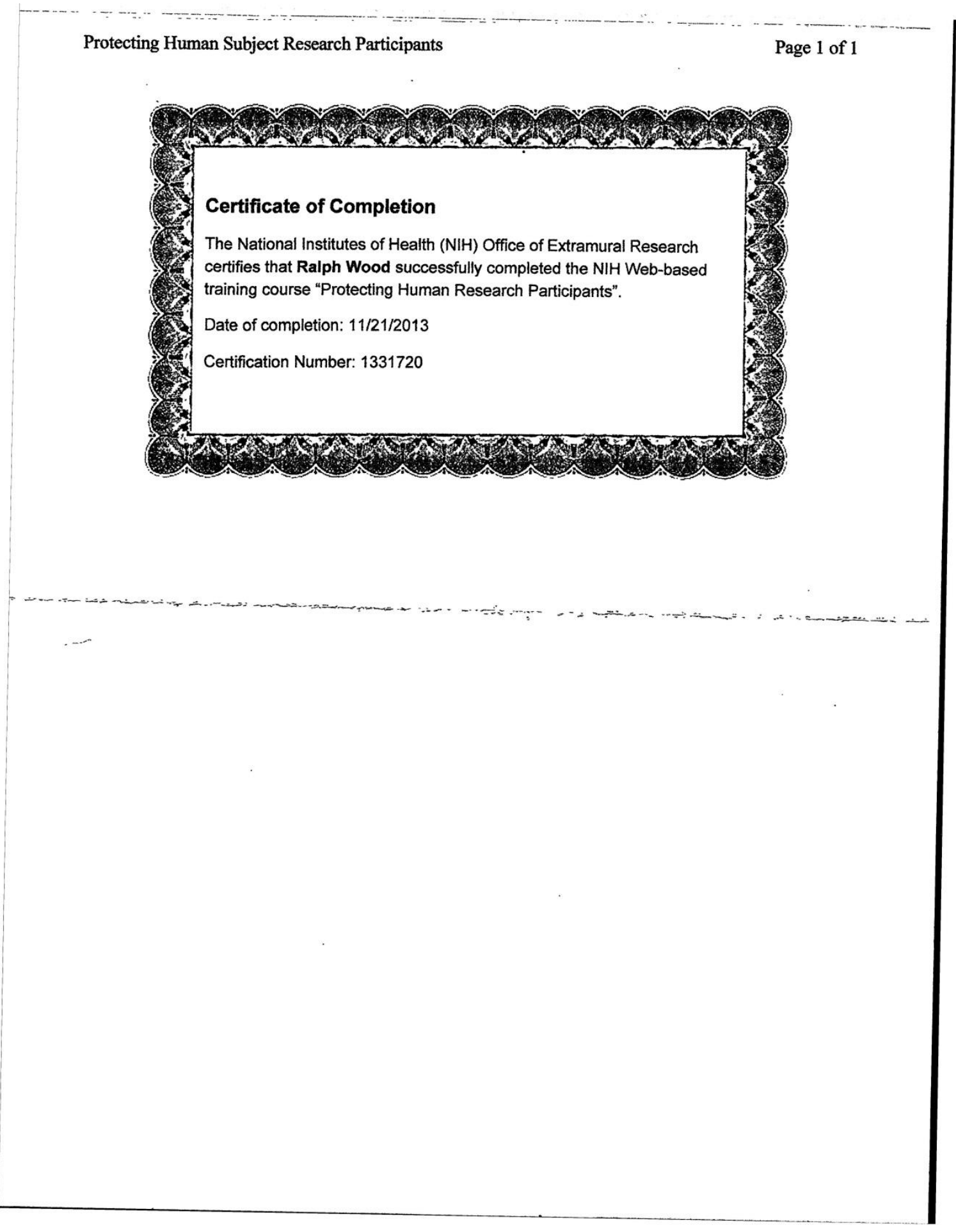


APPENDIX D

LETTER OF PERMISSION TO USE JARVIS ILLUSTRATION 
Permission Letter From Publisher to Uses Illustration

Gmail - FW: eFax message from "2694716035" - 2 page(s), Caller-ID: 126-434-2700

Page 1 of 3

Gmail

Ralph Wood < rcwood90@gmail.com>

FW: eFax message from "2694716035" - 2 page(s), Caller-ID: 126-434-2700 1 message

Bavister, Rosemary < ROSEMARY.BAVISTER@contractor.cengage.com>

Tue, Nov 26, 2013

To: "rcwood90@gmail.com" < rcwood90@gmail.com>

Dear Ralph

Re: Figure 1.6 in 'Towards a Comprehensive Theory of Human Learning'

Further to your recent email permission is granted for use of the above material in your forthcoming dissertation, subject to the following conditions:

1. The material to be quoted/produced was published without credit to another source. If another source is acknowledged, please apply directly to that source for permission clearance.

2. Permission is for non-exclusive, English language rights, and covers use in your dissertation only. Any further use (including storage, transmission or reproduction by electronic means) shall be the subject of a separate application for permission.

3. Full acknowledgement must be given to the original source, with full details of figure/page numbers, title, author(s), publisher and year of publication.

Yours sincerely

Rosemary Bavister

Permissions Administrator

Taylor \& Francis Books (UK)

Tel: +44 (0) 1264342781

https://mail.google.com/mail/u/0/?ui=2\&amp;ik=3f68270a86\&amp;view=pt\&amp;search... 11/26/2013 
APPENDIX E

\section{LISTS OF MIDA ALUMNI DEGREES}




\section{List of MIDA Alumni Undergraduate Degrees}

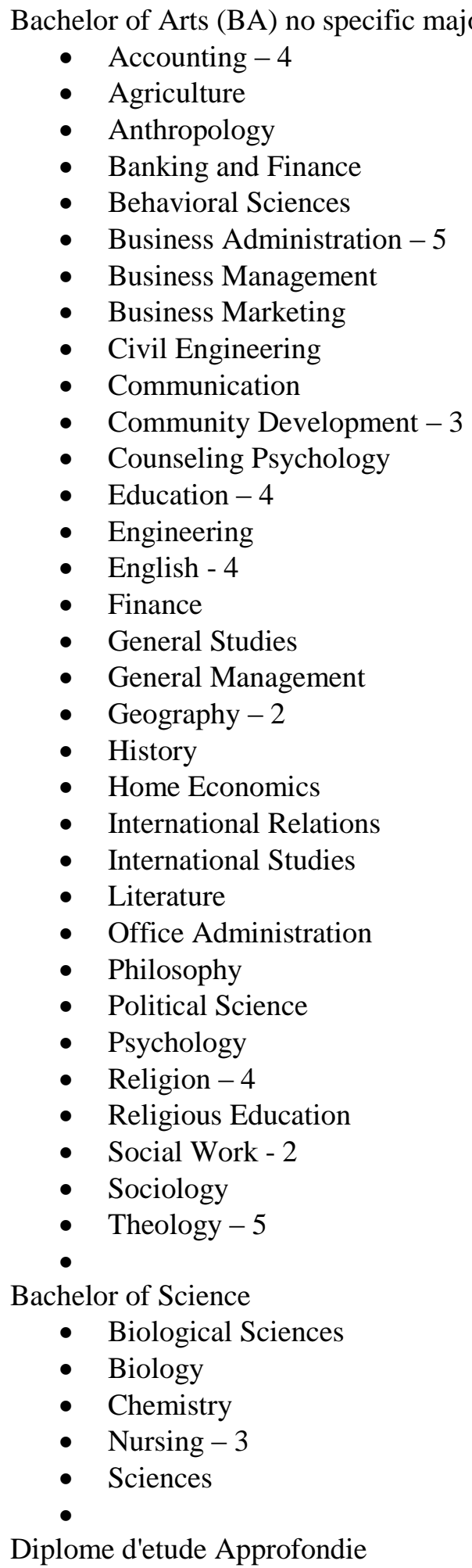


List of MIDA Alumni Post-graduate and Professional Degrees

Doctor of Divinity

Doctor of Medicine - 2

Master of Arts (no specific field of study) - 1

- Education -2

- Geography

- English

- Education Counseling

Master of Business Administration

Master of Public Health - Nursing

Master of Science

- Nutrition

- Hydrology and Water Resources

Master of Theology - 2

$\mathrm{PhD}$ (no specific field of study) - 2

- Agricultural Extension and Rural Sociology 


\section{APPENDIX F}

UNEDITED MIDA ALUMNI RESPONSES TO OPEN-ENDED QUESTIONS 


\section{Unedited Alumni Responses to Survey Question Number 56}

As you look back on your educational experience with the off-campus graduate program in international development offered by Andrews University, what would you say were the strengths of the program? - Open-Ended Response

1. It was very practical with the study work cycles. We learned, then practiced what we learned. We discussed real life issues and learned from them. Our homework was our real work.

2. provided access to professional development for practitioners... both financially and geographically

3. Devoted and helpful profs and course director

4. Close interaction between instructors and students Group assignments Experience sharing

5. For the one that are working, it gaves us the oportunity to combine work and studies. Most of the post-assignments allowed us to put into practice in an humanitarian context what we learnt in class. It was a very good oportunity to meet some other people for all over the world and share experiences.

6. allowed me to study while working hence was able to apply the study elements at work too.

7. Practical relevance to the field work

8. Practical application of the knowledge learned as when I studied we were already working with INGO

9. The financial arrangements made it easy for students at the time I took the MSA. It program was also not as common as now

10. The interaction between the students

11. networking with others within the industry, being able to combine working with the study opportunity

12. It affords students to study for graduate degrees while keeping their jobs. It enhance capacity in very practical way since students are able to apply practice to theory and vice versa. Very affordable and not as expensive as the on-campus program 
13. It was made available to me while I was employed as an ADRA Director. It was affordable. It was relevant to my work.

14. Some of the professors.

15. The course work was so practical for me and use up to today. The information that I got there has been so valuable to build my future.

16. Was Comprehensive, Provided a platform for global interaction and focused on program/project management

17. Very practical

18. The well experienced and knowledgeable Professors were very skillful and on-top of the subjects/topics -The reading materials and resources made available were very current and suitable to the courses

19. Communication, good following of students, availability and flexibility

20. The sharing of experiences by students

21. Professors have realistic knowledge about development sector. Subjects/materials taught were relevant. appropriate and good logistics for international students. Flexible teaching sites on different continents for different needs of students in terms of studying locations.

22. The timing or scheduling of the classes, the interaction with field development workers and the off the Class time with colleagues and teachers.

23. Exposure to people that were directly involved in the development and humanitarian work, such as Frank Brenda.

24. This was the best program I ever attended well delivered and managed. By tying the contents with the reality on the ground made the learning real and focused, Secondly the program gave the learners an opportunity to practice what they were learning through the various assignments and this helped ground the various concepts and finally, the cross culture made the entire program more rich in content and experience sharing.

25 1. Methods used to present learning material, and 2. Diverse backgrounds of learners

26 Part time and off campus, international professors 
27. VERY KNOWLEDGABLE PROFESSSORS EFFECTIVE COMMUNICAATION THROUGHOUT THE PROGRAM APPLICABILITY OF THE COURSE CONCEPTS

28. Experienced on the ground professors not only university teachers who never left the classroom! Also having the students that attend the class being experienced in the field development workers makes the program very unique!

29. The program participants and educators! The professors were well qualified and engaged students well. There were a broad range of ethnicities and professional backgrounds among students so we were all able to learn from each other and the information was relevant so I've been able to make use of the learning.

30. Applying concepts immediately at the field

31. Networking with other international development professionals and being able to draw on everyone's personal experiences

32. It has universal application

33. International setting which brings a fresh dynamic to the course and a great adaptation tool, that goes hand to hand with International Development.

34. Nearly ten years later, I am still grateful for the self-directed learning approach of the MSA program, and the genuine and unrestrained investment of the professors in us as students and colleagues.

35. Instructors were practitioners, fellow students were practitioners, exposure to different cultures / countries

36. The interaction with colleagues brings a large wealth of experience. I particularly enjoyed the African site, as all students were practitioners. The bulk of the professors were practitioners themselves, that added to the programs to large degree.

37. Well organized program; Highly qualified and committed instructors; Enough teaching materials of high quality

38. face-to - face classes and diversity students brings from various organizations and countries

39. program was great!!!!!!

40. Flexible for working people and more affordable than going full time to Andrews University 
41. Teachers were strong practitioners with lots of field experience, students were also practitioners.

42. The program is well design to reach the field people. The selection of the site were quite useful and appropriate. Those leading in the program understand the dylmics on the ground Some teachers understood the external environment and teaching adults

43. The assembling of people with varied backgrounds in development and from different environments

44. The program made me rise up in ranks. I was a Program Officer when I started the program and with the knowledge I learned from the program, I ended up being a Country Director after using the knowledge and skills gained from the program. It enabled me to achieve my goals and the goals of ADRA Successfully.

45. The management by Dawn and Paul, Flexibility for access to different sites, practice based lectures

46. Group dynamics

47. The program is very flexible to the need of adult learners, it focus on learning and sharing of experiences by students from different countries. The fact that this program keep moving from one country to an 4 had make very diverse it nature.

48. It had the material needed for the study at that time. This was a time when books in the field were not available but we got what was seeded. The 3, at least in the part of the world we studied, was not very good but we really got the books we needed and that to me was very great!

49. Cross cultural and knowledge and experience sharring opportunities among studenst.

50. Excellent and enhance the capacity of the student for leadership and professional post.

51. Networking with others of varied experiences, cultures, knowledge and values

52. Very good communication with the MSA office.

53. - International Experienced Professors - International Students with a broad scope of experiences to share

54 The professors had a wealth of knowledge and expertise not only in their courses but other areas as well. 2.) It brought together people from various backgrounds, with differing levels of experience and we were able to learn from each other. 
55. Sessions were highly interactive, Instructors used variety of methods and were knowledgeable, devotions were great.

56. Community. Networking.

57. Strategic locations of the program Professionalism of the instructors and research mentors Dedication of the program staff and diversity of students

58. done at home country. Although biased the director dawn was a nice person

59. Most of the professors used their own real-life experience to engage learners.

60. Diversity in staff and their professional backgrounds. 


\section{Unedited Alumni Responses to Survey Question Number 57}

As you look back on your educational experience with the off-campus graduate program in international development offered by Andrews University, what would be your recommendations on how the program could be improved? - Open-Ended Response

1. Keep it focused on people who are working, not those who haven't started working. Ensure that the teachers have had work experience in the area they are teaching.

2. Too many people were pushed thru to receive the MSA. The quality of their work was not up to Masters level and in many cases a certificate would have been a great achievement. It pulled down the quality of the degree. How many ADRA participants went on to leave ADRA soon after receiving the degree for higher paying jobs with other organisations? Was that the intention?

3. It's more effective if learners are the same knowlege level and not too much theory

4. More time allocation to courses Detailed presentation of research methodology Allocation of supervisors who have hands on experience on student research topic Close working relationship between supervisor and student

5. I had very very hard time to find the mentor for my research project. It took for long till Andrews University fillly helped me to find one. I took more than 6 months till receiving my scores for the final exam (when I shouldn't have taken more than 6 weeks). Therefore, my recommendations will be that Andrews could be "faster" on some issues.

6. None

7. (Professor ABC) was a typical embarassment to the program,most times you detected lack of preparation and inadequacy of the depth of topic under discussion. Choice of proffessors who have the passion to enhance capacity building even among Africans would be key. Lack of text books in the African site when the European site had them made it difficult to be able to quote those sources when conducting followup training sessions as means of multiplying effect of knowledge from MIDA.

8. Not sure now. Long time already, can't remember them.

9. Should be made more practical - with more field work

10. i did round 1.. so it has been a long time and many changes have probably taken place already since. I really enjoyed the program at the time.. there were always good courses, useful courses, good lecturers and not so good lecturers as 
expected. Most importantly is to get teachers who are experienced and have something to share from REAL experience, not just from being in academia.

11. A lot may have changed since I graduated from the program 15 years ago. However, I think that the online courses should take into consideration 3 connection challenges students face in developing countries. Programs that are compatible with low speed internet are preferable to those that require high speedy connectivity.

12. Remove classes that are irrelevant, ie. Statistics. These may be helpful for a business major but not for international development.

13. Better qualified instructors with FIELD experience, not just academic backgrounds.

14. Rethink about the person who walks the student though the research paper/thesis. It was a frustrating experience. Get someone most probably the student knows through the interaction in the course work and can work with the student with understanding since they already have interacted physically

15. Need for a strong course on statistics

16. More discussions on pre-session assignments

17. More access at the Program site should be addressed. Andrews University should clarify the admission process between her and the other Country institution site on the issue of issuance of admission letters( The question is it Andrews who admits students or it is the host site institution?

18. Statistic courses needs to be improved. Does not means the professors are not good. But it was our first course of statistic and found it very difficult. Need to be more easy to understand

19. Give more time for each course to enable students to conceptualize

20. back in 2010-2011, the statistic course was not well-prepared for online learning method yet therefore it created some difficulties for students and teachers. I hope it has been improved by now.

21. Dont invite teachers whose experience is creo in the intl. Devl. Work. Or people with no teaching skills at all. I had few of those and it was discouraging

22. Enhance the learning materials The program was a bit croweded and some courses required more time to be internalised. Consider making it short not to take 4 years .I do not know really how this can be done may be by allowing for more take home assigments by students and more online interactions. 
23. I think students take unnecessary time to complete the course. Therefore, I suggest that students start the research process from year one. These could build steadily throughout the year to end in year 4 or 3 depending on number of sites one attends per year.

24. Be sure Instructors are expert practitioners and have PhDs in the area of study

25. THERE IS A NEED FOR STUDENTS TO HAVE AN OPPORTUNITY TO ATTEND ONE SESSION AT THE UNIVERSITY CAMPUS. FOR EXAMPLE, PEOPLE APPRECIATE THE DEGREE I HVE FROM ANDREW UNIVERSITY, BUT UNFORTU1TELLY I DONT KNOW WHERE THE UNIVERSITY IS LOCATED, HOW IT LOOKS LIKE SO I FEEL SHY TO SAY I NEVER ATTENDED THE UNIVERSITY.

26. Always believe and take your student's feedback seriously in regards to the professors, site, logistics, etc....

27. There was a course in communication that did not seem relevant and the professor did not seem prepared, I think that has already changed and also offering the research course online and at the start was a good improvement.

28. Move to various parts of the world and conduct classes in their own set up.

29. What need to be done is to introduce the PHD program to enable the graduates advance there careers.

30. In our case a little bit more control over where people took their information to present in class (they should be original)

31. I was one of the last students to participate in a hybrid version of both the oncampus and off-campus programs. I benefited most greatly from the off-campus program, where I was able to engage in study and internships with fellow professionals from around the world. Many of us are still friends who stay in touch today. I think the program could be improved by continuing to allow oncampus students to opt into one term in an off campus program.

32. More practice. Give students time to do more reading and research. Too much time is wasted on useless talks power point presentations. Students and professor tell stories. Show sad videos of killings and bloodshed - Rwanda Genocide. Most professors copy facts and base their lectures on that. For example, professor of Community development course was telling us the number poor children in the world - a figure taken from UNICEF website. I do not need figures and facts. I need to know the way forward - how to address these problems and bring change? 
33. I wouldn't assume that everyone has dev experience going into the program - I had a really hard time with the M\&E class because I'd never had to evaluate a project before

34. Use practitioners from the NGO environment. Practitioners

35. Charge fees in local currency. Make use of MIDA as instructors where programs are offered.

36. include in the curriculum some aspects of real life experiences

37. More intentionally map out the different models/ approaches of various donors, focusing on key skills that are needed to navigate in this environment, there is also a growing need for inclusion of ICT / technology as a tool that is being used across donors

38. To assign lecturers who have theoretical and practical of experience in the field of their work. Not to confine students into doing only project research but open it for dissertation experiences

39. The timing is too short. I expect the number of meetings in a year to be increased.

40. During my time, we met once a year for three weeks session. The program was quite busy with lots to read and submit. I think if it is possible to increase the number of sessions per year eg. attend sessions twice a year and then reduce the amount of assignments or rather distribute the assignments according to the sessions. This will allow for a quality time on each assignment and ultimately good knowledge on the subject rather than rushing with the assignments to meet a deadline.

41. Reduce the requirements for completion please

42. Recruit professors who have hand's on experience not only academic knowledge (somebody with Hands on like David Ameya) would be a great value added to the class

43. The programme should provide more courses online and connect students from developing 1tion like South Sudan with scholarship opportunities globally to support their studies

44. It was too intermittent. In order to study well, one needed to concentrate on the education. Jumping from school to work disorganized things sometimes.

45. More time for the course sessions

46. The program should offer the Off-campus for PhD in International Development so that the MSA graduated can benefit for highest education. 
47. The courses changed too often, as did the time of the degree. It would be good to have more stability in those two aspects.

48. More on environmental aspects of development. More on future trends and criticisms of development. Faith and development work - how do they interrelate

49. - More emphasis on Faith in Development - More teaching how to actually conduct the final Research. - More emphasis on the bigger picture of the International Development are1, not only concentration on PCM. During my time, the MIDA curriculum focused a lot of PCM, which looking back now seems a bit narrow in view of the broader issues in International Development. PCM could be taken as a certification and not necessarily the entire focus of the MIDA. - Inclusion of more current issues of International Development.

50. An off-campus site needs to be established in the Caribbean/South America Area

51. It is ok as for now.

52. The program should be more intensive with two sessions in a year, in order to allow students to spend less time and graduate quicker.

53. Maybe connect all graduates to job opportunities and then use them later. Director should have a strong connection with NGOs so those are not working could be given a chance to exploit what the knowledge gained in MSA Like personally have never worked with any NGO, I wanted Dawn to connect me but she was biased. I asked for a recommendation she refused to give.

54. Increase the practicality of the statistics class.

55. Guidance on concentrations. Recommendations on internships and networking. 


\section{Unedited Alumni Responses to Survey Question Number 58}

As you look back on your educational experience with the off-campus graduate program in international development offered by Andrews University, how could the program be strengthened to meet the present and future needs of the international community? - Open-Ended Response.

1. It would improve the learning if all the assignments given in class were real life work that had to be completed. It could be a prerequisite to the course that each student needed to bring real work assignments in one of several areas. Also more focus should be given to the many different participatory approaches to find ones that really work in development.

2. The training material need to recognise the changes that are coming to the sector

3. World development work should be shared during course as learners come from different countries.

4. More localized programs Attachment of students

5. Don't know

6. Leadership skills and presentation

7. Not sure either. No longer in the NGO work. Thus, don't know what are practical and what not.

8. timing should be such that working people can attend, relevant courses that keep up with current development practices - which is always changing and new things being trialed all the time

9. The core competencies required of graduates should include quality writing skills. The quality of writing of some of the graduates that I have come across lately leaves a lot to be desired.

10. Offer more practical hands-on experiences and less theoretical. Have longer teaching sessions and more frequent learning. Spend much more time looking at current models used by competing NGO's.

11. Involve more practitioners, both ADRA and other UN/NGO

12. JUST KEEP OM REVIEWING THE COURSES AND ADD AND DROP AS THE DEVELOPMENT WORLD CHANGES

13. Continue to engage the alumni working in the development sector as part of the staff 
14. Instructors could recommend students attending more workshops organized by development partners

15. Strengthened communication and publicity about the Program

16. To find a way for student to finish earlier the program. Four years is long. Also student takes time to have their exam or to do their research as they are working too. Find a smooth way to allow them finish the course.

17. Include political focus on the courses. Empower students how to handle political challenges that hamper development.

18. Updated knowledge from professors about developing countries (especially countries in Asia) is good to include in their classes since when I was there, most of the examples were about Africa only.

19. Invite people from other organizations or schools to teach. Be more selective of the students/candidates, many of my peers did not have the level, nor the education requirements, to join the program and they were there all the time.

20. Enhance field projects .In this I think students should build on their projects early enough and work on them as they finalize their course work. I enjoyed the rotation into various countries and this could be coupled with field experiences especially if the element of inter1tioll experience has to be well captured. If possible all graduands should purpose to graduate at Andrews .

21. Reduce the years, and extend learning days and present learning at evening times when student come from work.

22. Provide good research methods skills

\section{THE PROGRAM SHOULD FOCUS MUCH ON FIELD PRACTICALS THAN CLASSES.}

24. Keep material on the cutting edge, introducing new methodologies, technology, emphasize on involvement, motivational factors, employee satisfaction! Also bring speakers from organizations that can talk about true success stories!

25. Look for the big issues in the world and who is making strides and helping people really realize their basic human rights. What about displaced people and human trafficking? Also there was a heavy emphasis on ADRA, but invite more practitioners from other organizations to share successful ideas, or maybe alumni who have made good progress. 
26. International and Community Dev. is part of Jesus' Gospel.

27. Networking beyond the ADRA network with other INGOs and donors

28. By introducing the PHD

29. A course or section that would include all the new trends and what directions are being taken by the big players of International development with real examples and ways to manage integration of these to the different cultural settings. Including a little bit of how we can find the proper ways to approach or convey our needs in a diplomatic and culturally correct manner.

30. The landscape of ID has shifted greatly in the decade since I graduated, as well as have the methods in which the world communicates with each other. I believe that adding a course or at least a series of lectures and activities on best practices in branding and digital media communications for fundraising and constituent engagement would be vital for a well-rounded program.

31. knowledgeable professors should be recruited. Need-based curriculum should be prepared. professors should not waste students' time by giving them some journal articles to prepare power point presentations. It should more practicle. It should be: Concept - understanding - application. meaning what was the concept? what is student's understanding? How to apply it on the ground?

32. I would really put more emphasis on the importance of anthropology in intl dev

33. Add classes related to the Networking and fundraising, as it is a very important need to all leaders in the NGO environment. Also add filnces, but from a sustailbility point of view, creating standards of sustailbility, which each student can look up to.

34. Offer job opportunities whenever an opportune knocks such as Adra, World Vision etc. Start a PhD program for the same. off refreshers courses at affordable fee for alumni in Andrews University Michigan

35. add some components of Peace building and conflict mitigation, emergency preparedness and response and International Humanitarian law

36. it was very good when I have been taking course

37. Continue to use practitioners in the training, and the content will 1turally remain contextualized.

38. to review the current program and update some courses to reflect the emerging changes in development. There is a lot happening in the humanitarian sector yet, the program is still ignorant to this. there should be a blend between development 
and relief framework that will open opportunities to learn and be instruments to both development and relief.

39. The Alumini should be strengthened and yearly meetings organized somewhere in the world and not necessarily on Andrews University Campus

40. I think it is important to continuously update the subjects. For example fundraising has been changing and being diversified constantly. In South Sudan, we ended up bidding with big for profit companies for project funds but we did not have the skills for bidding as we were used to a different way of fundraising.

41. Scholarships for talented people in developing countries should be increased as the real problem is in developing countries and not everyone can afford the cost of travel.

42. The program should continue its first practices of admitting people with field experience and not candidates without experience

43. The programme can be strengthen through more courses made available on online to give student more time to study earlier and then revise when attend intensive classes.

44. A little more exposure to different environments would improve the program

45. Inviting previous off-campus graduate students to a few days experience sharing workshop to know what has changed in the working environment since they last graduated to contemporarily update future course contents.

46. Offer PhD in International Development for off-campus students.

47. NB did you get good input into the survey design? This looks more like an undergrad level survey than postgrad.

48. There needs to be more emphasis on the on-line community - from proposal writing to fund-raising. Social media is a very powerful tool that should be utilized by more NGOs, especially ADRA.

49. - Online Forum for students to share their experiences - Connect students with websites and other current learning platforms - Require/facilitate a minimum infield experience time - Focus on sustailbility of NGOs in the contemporary International Development industry

50. Ensure that the participants submit an actual or winning proposal/grant to an agency for funding, before graduation

51. The program should be flexible to include any emerging needs. 
52. The program should include/incorporate demanding courses to meet the needs of the international community.

53. Start a doctoral program in Development so as to have enough manpower in the respectful countries when this program is offered

54. I'm not sure as I no longer work in the international development field.

55. Work with a variety of ID professionals and orgs around the world, for professionals in the field and entry-level professionals. 
REFERENCE LIST 


\section{REFERENCE LIST}

About Education. (2014). Differences in descriptive and inferential statistics. Retrieved February 3, 2015, from http://statistics.about.com/od/DescriptiveStatistics/a/Differences-In-Descriptive-And-Inferential-Statistics.htm.

ADRA International. (2005). ADRA international operations manual. Silver Spring, MD: Adventist Developent and Relief Agency.

ADRA International. (2013). ADRA employment/volunteer/internship information Retrieved July 5, 2013, from http://www.adra.org/sitePagenavigator/about_usinternsjips.html.

Albreight, W. F. (1957), From the stone age to Christianity: Monotheism and the historical process (2nd ed). New York: Doubleday.

Andrews Study Bible: Light, depth, truth. (2010) Andrews University Press. Berrien Springs, MI.

Andrews University. (2012). Andrews University academic bulletin, 2012-2013 (Vol. 101). Berrien Springs, MI.

Andrews University. (2013). Andrews University academic bulletin, 2013-2014 (Vol. 102). Berrien Spring, MI.

Bangledesh Rural Advancement Committee. (2015). Who we are. Retrieved March 3, 2015, from http://www.brac.net/content/who-we-are.

Bollen, K. A., (2002). Latent varibales in psychology and the social sciences. Annual Review of Psychology, 53, 605-34.

Borden, V. M. H. (2005). Using alumni research to align program improvement accountability. New Directions for Institutional Research, 2005(126), 61-72.

Brigham Young University. (2015). Research methods: planning: variables. Retrieved January 15, 2015, from http://linguistics.byu.edu/faculty/henrichsenl/ResearchMethods/RM_2_14.html.

Cabrera, A. F., Weerts, D. J., \& Zulick, B. J. (2005). Making an impact with alumni surveys. New Directions for Institutional Research, (126), 5-17. 
Capacity building. (2015). In BusinessDictionary. Retrieved March 3, 2015, from http://www.businessdictionary.com/definition/capacity-building.html.

Catholic Relief Services. (2011). About us. Retrieved October 21, 2011, from http://crs.org.

Chin, H. (2008). Using training to build capacity for development: An evaluation of the World Bank's project-based and training WBI. Washington, DC: The World Bank. Retrieved December 18, 2014, from http://siteresources.worldbank.org/EXTTRABUICAPDEV/Resources/full_ doc.pdf.

Connolly, P., \& Lukas, C. (2002). Strengthening nonprofit performance: A funders guide to capacity building. Saint Paul, MN: Wilder Publishing Center.

Creswell, J. W. (2014). Resaerch design: Qualitative, quantitative, and mixed methods appraoches (4th ed.). Los Angles: SAGE.

Crocker, D. A., \& Schwenke, S. (2005). The relevance of development ethics for USAID. Washington, DC: Management Systems International Corporate Offices.

Crossley, D. A., \& Holmes, K. (2001). Challenges for educational research: International development, partnership and capacity building in small states. Oxford Review of Education, 27(3), 395-409.

de Crombrugghe, D. (2010). Evaluation of NGO partnerships aimed at capacity development. Brussels: FPS Foreign Affairs, Foreign Trade and Development Cooperation.

Department of Economic and Social Affairs. (2013). Basic Facts about ECOSOC Status Retrieved June 20, 2013, from http://csonet.org.

DeVita, C. J., \& Fleming, C. (Eds.). (2001). Building capacity in nonprofit orgnizations. Washington, DC: The Urban Institute.

Drucker, P. (1993). Post-capitalists society. Oxford: Butterworth-Heinemann.

Eade, D. (1997). Capacity-building: An approach to people-centered development. Oxford, United Kingdom: Oxfam (UK and Ireland).

European Commission. (2004). Project cycle management guidelines: Supporting effective implementation of EC External Assistance, Volume 1. Brussels: European Aid Cooperation Office (EuropeAID). Retrieved October 18, 2014, from http://ec.europa.eu/europeaid/sites/devco/files/methodology-aid-deliverymethods-project-cycle-management-200403_en_2.pdf 
Ewell, P. T. (2005). Alumni studies as instruments of public policy: The U. S. experience. New Directions for Institutional Research 2005(126), 19-29.

Food and Agriculture Organizations of the United Nation. (2008). Capacity building: Foreign affairs, trade and development Canada. Retrieved August 7, 2014, from www.international.gc.ca.

Greiman, V. (2011). Guide on international development: Public service careers and opportunities. Cambridge, MA: Harvard Law School.

Hoey, J. J., \& Gardner, D. C. (1999). Using surveys of alumni and their employers to improve an institution. New Directions for Institutional Research, 1999(101), 4359.

Horton, D. (1998). Building capacity in planning, monitoring and valuation: Lessons from the field. ISNAR - International Service for National Agricultural Research. Retrieved March 20, 2015, from: ftp://ftp.cgiar.org/isnar/Publicat/discuss/dp9819.pdf

Howell, D. C. (2002). Statistical methods for psychology. Boston: Duxbury/Thomson Learning: Boston.

International Development Program. (2014). 2015 Student policy handbook. Andrews University, Berrien Springs, MI. Retreived January 15, 2015, from http://www.andrews.edu/grad/idp/publications/StudentPolicyHandbook2015English.pdf.

Jarvis, P. (2006). Toward a comprehensive theory of human learning: Lifelong learning and the learning society (Vol. 1). London: Routledge.

Khan, N. (2013). BRAC USA 2011 annual report Retrieved June 6, 2013, from http://prezi.com/5xscrzwgt5pw/brac-usa-2011-annual-report/.

Knight, J. (2006). Higher education in the world 2006: The finiancing of universities. New York: Palgrave MacMillan.

Knowles, M. S., Holton, E. F. I., \& Swanson, R. A. (2005). The adult learner: The definitive classic in adult education and human resource development ( $6^{\text {th }} \mathrm{ed}$.). Burlington, MA: Elsevier.

LaFond, A., \& Brown, L. (2003). A guide to monitoring and evaluation of capacitybuilding interventions in the health sector in developing countries. Development Policy Journal, 1, 1-95. 
Laird Statistics. (2015). Descriptive and inferential statistics. Retrieved February 3, 2015 from https://statistics.laerd.com/statistical-guides/descriptive-inferentialstatistics.php.

Lewis, D. (2008). Non-governmental organisations (NGOs) and poverty reduction. Retrieved February 14, 2012, from http://www.iprcc.org.cn/ppt/2008-0410/1207780830.pdf.

Lewis, D. (2009). Nongovernmental organizations, Definition and history. Berlin: Springer-Verlag.

Logical Framework Approach. (2015). Downloaded December 13, 2015, from http://www.sswm.info/content/logical-framework-approach

Logical Framework Approach. (2015). Logical framework approach. Retrieved October 30, 2015, from http://www.sswm.info/content/logical-framework-approach.

Lusthaus, C., Adrien, M.H., \& Perstinger, M. (1999, September). Capacity development: Definitions, issues and implications for planning, monitoring and evaluation. Universalia Occasional Paper, 35, 1-21.

McCallin, A. (2015). Why we like grounded theory. Grounded Theory Online: Supporting Grounded Theory Reseachers. Downloaded February 1, 2015, from http://www.groundedtheoryonline.com/what-is-grounded-theory.

McMillan, J. H., \& Schumacher, S. (2001). Research in education: A conceptual introduction (5th ed.). New York: Longman.

Meehl, P. (1990) Why summaries of research on psychological theories are often uninterpretable. Psychology Reports, 66, 195-244.

Merriam, S. B., Cuffarella, R. S., \& Baumgartner, L. M. (2007). Learning in adulthood: A comprehensive guide ( $3^{\text {rd }}$ ed.). San Francisco: Jossey-Bass.

Meyers, L. S., Gamst, G. \& Guarino, A. J. (2013). Applied multivariate research: Design and interpretation. Los Angeles:Sage.

Morgan, P. (1998). Capacity and capacity development: Some strategies. Ottawa, Ontario: Canadian International Development Agency (CIDA).

National Institute of Health (NIH). (2014). Protecting human research participants. Retrieved from https://phrp.nihtraining.com/users/login.php?l=3.

Newman, I., Benz, C. R., Weis, D., \& McNeil, K. (1997). Theses and dissertations: A guide to writing in the social and physical sciences. Lanham, MD: University Press of America. 
Organization for Economic Co-operation and Development. (2001). Cities and regions in the new learning economy. Paris: OECD.

Oregon State University. (2012). Definition of anthropological terms. Retreived January 19, 2015, from http://oregonstate.edu/instruct/anth370/gloss.html\#T.

Osborne, J. W. (2013). Best practices in data cleaning: A complete guide to everything you need to do before and after collecting your data. New York: Sage.

Roberts, D., \& Khattri, N. (2012). Designing a results framework for achieving results: A how-to guide. Retrieved September 6, 2014 from http://ieg.worldbank.org.

Rosenkranz, R. (2011). Global development: what you need to know. Retrieved August 8, 2014, from https://www.devex.com/news/global-development-what-you-needto-know-74999.

Santrock, J. W. (1992). Life-span development. Dubuque, IA: Wm. C. Brown Publishers.

Save the Children. (2013). Internship--Save the Children. Retrieved July 5, 2013, from http://www.savethechildren.org/site/c.8rKLIXMGIpI4E/b.863185/k.9CAE/Intern ships.htm.

Scott, H. (2009). What is grounded theory? Grounded Theory Online: Supporting Grounded Theory Researchers. Downloaded February 1, 2016, http://www.groundedtheoryonline.com/what-is-grounded-theory.

Sessions, K. (1993). Building capacity for change. EPA Journal, 19(2), 15-19.

Survey Monkey. (2015). How to analyze results. Retrieved January 15, 2015, from http://help.surveymonkey.com/articles/en US/kb/How-to-analyze-results.

Tashakkkori, A., \& Teddlie, C. (Ed.). (2010). Sage handbook of mixed methods in social \& behavioral research, 2 ed. London: Sage.

The top 100 NGOs of 2013. (2013). Retrieved July 12, 2014, from http://theglobaljournal.net/top100ngos.

The World Bank. (2014). About: What we do. Washington, DC. Retrieved August 19, 2014, from http://www.worldbank.org/en/about/what-we-do.

Third World. (2013). In BusinessDictionary. Retrieved March 3, 2015, from http://www.businessdictionary.com/definition/Third-World.html.

Thomas, T. (2000). Poverty and the end of development. Oxford, England: Oxford University Press. 
Thorndike, R. M. \& Dinnel, D. L. (2001). Basic statistics for the behavioral sciences. Upper Saddle River, NJ: Prentice-Hall.

Truman, H. S. (1949). Inauguration address by Harry S. Truman. Washington DC: Joint Congressional Committee on Inaugural Ceremonies. Retrieved August 8, 2014, from http://www.inaugural.senate.gov/swearing-in/address/address-by-harry-struman-1949.

Tulane University (2015). Data cleaning. Retrieved January 18, 2015, from http://www.tulane.edu/ panda2/Analysis2/datclean/dataclean.htm.

United Nations. (2014). United Nations rule of law: Non-governmental organizations. Retrieved August 21, 2014, from http://www.unrol.org/article.aspx?article_id=23.

United Nations Development Program. (1998). Capacity assessment and development in a systems and strategic management context (Technical Advisory Paper No. 3). New York: United Nations Development Program (UNDP).

United Nations Development Program. (2007). Supporting capacity development: The UNDP approach. New York: The United Nations Development Programme.

United Nations Development Program. (2010a). Capacity is development: A global event on smart strategies and capable institutions for 2015 and beyond. New York: United Nations Development Program.

United Nations Development Program. (2010b). Capacity development frame. New York: United Nations Development Programme (UNDP).

United Nations Development Program. (2013, March). Knowledge, innovation and capacity development. Retrieved November 20, 2013, from www.undp.org/capacity.

United Nations Educational, Scientific, and Cultural Organization. (2015). Types of variables. Retrieved January 18, 2015, from http://www.unesco.org/webworld/idams/advguide/Chapt1_3.htm.

United Nations Environmental Program (2006). Ways to increase the effectiveness of capacity building for sustainable development. Geneva, Switzerland: United Nations Environment Programme. Retrieved August 8, 2014, from www.unep.ch/eth . 
United States Agency for International Development. (2014a). Fact Sheet: FY 2014 Development and humanitarian assistance budget. Retrieved August 19, 2014, from http://www.usaid.gov/sites/default/files/documents/1869/FY2014_DevelopmentB udgetFactSheet.pdf.

United States Agency for International Development. (2014b). Knowledge management support. Retrieved October 30, 2015, from https://www.usaid.gov/results-anddata/information-resources/knowledge-management-support.

United States Agency for International Development. (2015). Budget. Retrieved March 11, 2015, from http://www.usaid.gov/results-and-data/budget-spending.

US Legal. (2014). Global development law \& legal definition. Retrieved August 8, 2014, from http://difinitions.uslegal.com/g/global-development/.

Van Velzen, J. H. (2013). Educational researchers and practicality. American Educational Research Journal, 50(4), 789-811.

Walton, J. H. (1994). Covenant: God's purpose, God's plan. Grand Rapids, MI: Zondervan.

Warner, R. W. (2013). Applied statistics: From bivariate through multivariate technques $\left(2^{\text {nd }}\right.$ ed). Los Angeles: Sage.

White, E. G. (1903). Education. Mountain View, CA: Pacific Press.

Williams, R. (2015). Intro to path analysis. Downloaded September 15, 2015 from http://3.nd.edu/ rwiliams/ last revised April 6, 2015.

Willis, K. (2005). Theories and practices of development. New York: Routledge.

Wing, K. T. (2004). Assessing the effectiveness of capacity-building initiatives: Seven issues for the field. Nonprofit and Voluntary Sector Quarterly, 33(1), 153-160.

Wuensch, K. L. (2014). Conducting a path analysis with SPPS/AMOS. Downloaded September 15, 2015 from: http://core.ecu.edu/psyc/wuenschk/MV/SEM/Path-SPSS-AMOS.pdf. 
VITA 
VITA for Ralph Charles Wood, Jr.

\section{EDUCATION}

1972 B.S. Livestock Production, Loma Linda University

1974 M.P.H. Tropical Diseases \& Environmental Health, Loma Linda University

1976 K-12 Vocational Agriculture Teaching Certificate, University of Nebraska

2016 Ph.D. Curriculum and Instruction, Andrews University

\section{ACADEMIC POSITIONS HELD}

Instructor, Hayes Center High School, Hayes Center Nebraska

1979-1982 Chairperson, Department of Agriculture, Pacific Union College, Angwin, California

1985-1992 Dean, School of Agronomy, Dominican Adventist University, Santo Domingo, Dominican Republic

1999-2011 Assistant Professor, Andrews University, Berrien Springs, Michigan

\section{PROFESSIONAL WORK EXPERIENCE}

1974-1976 Assistant Farm Manager, Platte Valley Academy, Shelton, Nebraska

1977-1979 Assistant Director, SAWS Sahel Irrigation Development Project, Chad, Africa

1992-1999 Manager, Twixwood Nursery, Berrien Springs, Michigan

\section{HONORS AND AWARDS}

1966 Frank Judson Agriculture Scholarship, La Sierra College

1966 Music (Band) Scholarship, La Sierra College

1992 Excellence in Teaching Award, Dominican Adventist University 
